\title{
The Holy Crown of Hungary, Visible and Invisible
}

\author{
LÁSZLÓ PÉTER
}

The reader at this point will certainly ask: how it is possible that a national relic of such great significance has never been properly examined in order to attain satisfactory conclusions [about its origin]. The answer is as contradictory as unexpected: precisely because such importance was attached to the crown; because it has been treated as the greatest national treasure.

Kálmán Benda and Erik Fügedi on the Holy Crown ${ }^{1}$

The history of political ideas reveals continuities and unexpected revivals. Too frequently it proves premature to pronounce a political idea dead. A well-known example which demonstrates that major political ideas hardly ever disappear without trace has been the reemergence of the natural law theory which had spent years in the doldrums while utilitarianism dominated political philosophy in Britain and America. ${ }^{2}$ Ideas whose impact is more limited and confined to a single national society could, likewise, unexpectedly revive after their apparent demise.

When over forty years ago the present writer, working towards his DPhil in Oxford, took up the doctrine of the Holy Crown of Hungary, he thought that the subject was of purely historical interest, or at least one without any direct relevance to Hungarian politics, present and future. The reason why this assumption looked obvious at the time was not even primarily because Hungary, as a part of the Soviet bloc, was ruled by Communists who rejected and sneered at any political

László Péter is Emeritus Professor of Hungarian History at the School of Slavonic and East European Studies, University College London.

I am grateful to Professor János Bak (CEU, Budapest) for raising critical questions about the text, to Professor James Burns (UCL) for his point on Hegel's influence, to Dr Lóránt Czigány (London) for his comments on my use of terms, to Professor R. J. W. Evans (Oxford) for his incisive observations, to Virginia Hewitt (British Museum) for a piece of information, to Dr Martyn Rady (SSEES, UCL) for detailed criticism and archival references, to Judit Villám (Parliamentary Library, Budapest) for providing a copy of a colligatum she compiled, in I 999, of recent publications on the Holy Crown question. Finally, I should like to thank my wife, Margaret, for her suggestions for improving the grammar and style of the text. In the use of capital letters for 'Holy Crown', I follow established convention (the use of lower case would amount to the making of a political point).

Kálmán Benda and Erik Fügedi, Tausend Fahre Stephanskrone, Szeged, I 988, translation of A magyar korona regénye, Budapest, I 979 (hereafter, Stephanskrone), p. 20.

2 The revival followed the appearance of John Rawl's A Theory of Fustice, Cambridge, MA, I97I. 
tradition of the old order which they replaced. ${ }^{3}$ The reason went deeper: it was generally taken for granted, even by opponents of the Communist regime, that political traditions, like the ideas of the Holy Crown, however important they had been in past centuries, were closely tied to the institution of the monarchy that had irretrievably perished by the end of the Second World War. By i 945 the whole traditional social order that used to maintain the institutions of the kingdom was gone. It is true that even after I 945 some émigré groups of the displaced political élite, having escaped to the West from Nazi or Communist rule, cherished old political traditions including ideas about the Holy Crown. ${ }^{4}$ In the ig6os a Hungarian scholar, Charles d'Eszlary, published in France a three-volume history of the Hungarian political institutions from the Middle Ages, ${ }^{5}$ considered largely in terms of the Holy Crown doctrine (the doctrine was a late-nineteenth-century innovation, of which more later). He must have been a 'last Mohican'. For the world at large, so far as it took cognizance of Hungarian constitutional matters, the doctrine was as dead as the dodo.

Yet, the reports of the death of the Holy Crown tradition turned out to be greatly exaggerated. Come i 989, Eastern Europe's annus mirabilis, Soviet power in the region collapsed and, together with that, Communist rule. Hungary, like a few other former satellites, became a parliamentary democracy. There was no question of restoring either the monarchy or the old social order. And yet the Holy Crown, like that fabled Egyptian bird, the phoenix, miraculously came forth with new life. The revival, as in the past, touched on the visible St Stephen's Crown as well as the invisible crown of ideas. Further, what makes the revival notable is that, as so frequently in the past, the 'crown question' stirred up an unusually large amount of political dust. ${ }^{6}$ Indeed, at one point the Academy of Sciences had to intervene to resolve the political conflict generated by the revival of the tradition. Leaving out antecedents, to which I shall in due course return, the millennial celebrations provided the occasion for the revival of a cult with remarkably strong roots. For, in Hungarian political rhetoric and historiography, the

\footnotetext{
${ }^{3}$ I am informed that after 1945 the Law Faculty at the University in Budapest had on its noticeboard: 'No dissertation will be considered on the law of rape and on the doctrine of the Holy Crown'.

${ }^{4}$ Even in Hungary not everybody changed their political beliefs after the War. I recall a meeting with an old fogey in Budapest in I 955 before his arrest, secret trial by the ÁVH and subsequent death in prison, who thought that the Russians would soon leave Hungary when a nádor (palatine) was elected and the monarchy restored after a plebiscite.

${ }^{5}$ Histoire des institutions publiques Hongroises, Paris, I ( I 959), 2 ( I 963 ), 3 (I 965).

${ }^{6}$ A perplexing case is Kim Lane Scheppele's who writes that by moving the crown to parliament (see below) 'it has become a symbol concentrating the dark passions of Hungarian conservatism, particularly those that move toward fascism', 'The Constitutional Basis of Hungarian Conservatism', in East European Constitutional Review, 9 (Fall 200o), 4, pp. $5 \mathrm{I}-57$ (p. 5I).
} 
second millennium is intimately connected with the first. St Stephen, who turned Hungary into a Christian kingdom, was crowned at Christmas in AD I ooo. In December I 999, after sharp debates between the ruling coalition of the moderate right parties, parliament passed a bill which commemorated the establishment of the State one thousand years ago and ordered the Crown of St Stephen, otherwise known as the Holy Crown, together with the other coronation regalia, to be transferred from the National Museum to parliament for the millennial year. ${ }^{7}$ On I January 2000, it was reported, the crown

was placed inside a glass cabinet and carried under heavy security in an armoured car followed by a motorcade. A guard of honour carried it up the stairs into parliament and then a gun salute was fired over the River Danube. ${ }^{8}$

The regalia were received by the Corporation (testïlet) of the Holy Crown, created by the Law, consisting of the Republic's highest office holders. ${ }^{9}$ The President of Parliament opened the celebration. Then the President of the Republic signed Law I of 2000 'To Commemorate the Establishment of the State by St Stephen and the Holy Crown'. ${ }^{10}$ The preamble of the Law referred to the Holy Crown as 'the relic living in the memory of the nation and Hungarian constitutional tradition that embodies the continuity and independence of the Hungarian State'. Paragraph 2 of the Law ordered the transference of the Holy Crown to parliament. In his Address, the President said that the crown had for centuries signified the supreme power shared between the king and the nation as the crown's members. ${ }^{11}$ This was followed by the Prime Minister's speech with the following operative passage:

\footnotetext{
7 The government bill was passed on 2 I December I 999 by a large majority after most of the references to the 'doctrine' of the Holy Crown were deleted from the ministerial draft. The bill (T/ı8ı6) 'A Szent István-i államalapítás emlékének megörökitéséről és a Szent Koronáról' was submitted by Ibolya Dávid, Minister of Justice, in November i 999 and passed by the House's Constitutional and Judicial Committee on I December (T/ I 8 I6/32). The bill's preamble was then substantially shortened by the House before it passed as Law I 2000, Magyar Közlöny, I January 2000, pp. I-2. The Centre-Right government gave way after the forceful intervention by the President of the Hungarian Academy of Sciences whose team of historians sanitized the text of the preamble: see László Szále and László N. Sándor, 'Tudomány és közélet', Magyar Tudomány, 200o/6, pp. 736-4I (interview with President Ferenc Glatz). Also, the Opposition, before its revision, threatened to take the bill to the Constitutional Court. Still, the political Left, the Free Democrats and many Socialist deputies either voted against the revised bill or abstained and stayed away from the subsequent celebrations.

${ }^{8}$ The Times, 3 January 2000.

${ }^{9}$ Created by para. 5 of the Law. Its members are the President of the Republic, the Minister President, the President of Parliament, the President of the Constitutional Court and the President of the Hungarian Academy of Sciences.

${ }_{10}^{10}$ Magyar Közlöny, I January 2000, pp. I-3.

${ }^{11}$ This is the gist of the doctrine of the Holy Crown, deleted from the bill after debate but affirmed by the President of the Republic. Magyar Nemzet, 3 January 2000, pp. I and 5.
} 
the head of the Christian Church sent a crown to Stephen to make him anointed king; the king who created nation and patria; the country that through struggles, strife and sacrificed lives became a part of Christian Europe. This crown created the possibility for Hungary's entry into Europe. ${ }^{12}$

Clearly, independent statehood and entry into Europe are the two mantra phrases today in the rhetoric associated with the Holy Crown.

It is too early to speculate on how far these solemn flourishes about the crown will go beyond the millennial celebrations. There is plenty of opposition particularly in the Budapest left-wing intelligentsia to the new political rhetoric about the crown. Yet what has already happened clearly demonstrates that for many Hungarians the crown tradition is still alive and well. ${ }^{13}$

When we examine Hungarian political rhetoric concerning the Holy Crown, the first striking fact to observe is the central importance of the visible, material diadem in the generation of the crown tradition. We have to discuss, therefore, however cursorily, the provenance and the political role of St Stephen's visible crown before turning to the invisible corona, a multivocal term, and its uses in the past and the present.

\section{The Crown of St Stephen and its provenance}

It is doubtful whether there have ever been bestowed upon regalia, or indeed any object, ${ }^{14}$ in a European country the cult and such an enduring political role that have been accorded to the Crown of St Stephen. ${ }^{15}$ For centuries the diadem itself was not even clearly distinguished from the ideas associated with the crown. Sanctity, 'inamissibility' and mystery were attributed to the diadem in the Middle Ages which then retained a central place in modern constitutional politics. The provenance of the diadem is uncertain. Moreover, the expansion of research over the years has only increased rather than reduced the uncertainties about the origin of the crown's various parts. The vast literature on the subject reached consensus only on the two points that (i) the crown which has borne his name for centuries, never embellished St Stephen's head, and that (ii) the crown was assembled

\footnotetext{
12 Ibid., p. 5 .

13 This is inadvertently recognized even by the opponents of its present revival when they criticize the government for taking up the crown tradition in order to do better in the opinion polls.

14 The Stone of Scone (Destiny) on which Scottish kings were crowned has had a longer history than the Hungarian diadem but it did not become a repository of ideas and rights. The Black Stone of the Kaaba in Mecca is purely religious.

${ }^{15}$ Curiously, this point has been neglected by Hungarian scholars. But see Zoltán Tóth, A Hartvik-legenda kritikájához, Budapest, i 942, p. 97.
} 
from parts with different provenance. ${ }^{16}$ The lower crown, the so-called corona graeca, is a wide circular golden rim with enamels and stones to which pinnae (finials) are attached. This part of the crown might have been a gift crown, which was subsequently rearranged, or some other gift from Michael VII, Byzantine Emperor ( 107 I-I 078 ) to King Géza (1074-I077), or more probably his wife. ${ }^{17}$ Opinion diverges even more widely on the nature of the upper crown, the so-called corona latina. This consists of two intersecting bands with eight enamels, each portraying an apostle, and, where they overlap, the ninth and largest enamel which portrays the Pantocrator, crudely mutilated by the hole to hold the surmounting cross which later went crooked. ${ }^{18}$ Theories on the original function of the upper intersecting bands are many. Also, some scholars date the bands from the time of St Stephen; ${ }^{19}$ others from the twelfth century. On the date of the crown's assembly in its present form, disregarding (with respect) some extravagant ideas about the whole crown being assembled in the year sooo, or even centuries before, opinion, once more, varies between the late eleventh and the fifteenth centuries, the late twelfth century being the favourite. ${ }^{20}$ Nor is there, so far as one can see, consensus as regards the type of the assembled crown; is it a stephanos, a stemma or kamelaukion? ${ }^{21}$

\footnotetext{
${ }^{16}$ Neither point is surprising. Crowns named after founder kings are frequently from later periods and may be assembled from parts with different origin. Concerning the large literature see Iván Bertényi, A magyar Szent Korona, Magyarország cimere és zászlaja (hereafter, Szent Korona), fourth edn, Budapest, I996. A bewildering diversity of conflicting hypotheses and conclusions emerge from the author's summary of recent research, pp. 27-56. Éva Kovács, leading art historian, assessed in two chapters in her Species modus ordo (Budapest, I998) the research into the Hungarian regalia since the Second World War, pp. 9-I4 and 386-400; Éva Kovács and Zsuzsa Lovag. The Hungarian Crown and Other Regalia, 2nd ed., Budapest, I 980, offer the best photos, independent views and a short summary of recent research. Three important earlier studies from the post-war literature: Albert Boeckler, 'Die "Stephanskrone", in P. E. Schramm, Herrschaftszeichen und Staatssymbolik III, Stuttgart, I 956; P. J. Kelleher, The Holy Crown of Hungary, Rome, I95 I (hereafter, Holy Crown); Josef Deér, Die heilige Krone Ungarns, Vienna, I 966 (hereafter, Die heilige).

17 Most experts, following Magda Bárány-Oberschall and Josef Deér's studies, assume the original gift to have been a female crown.

${ }^{18}$ Sign of wear and tear or that of a botched job because of haste in the assembly of the diadem during a succession crisis?

${ }_{19}$ Kelleher suggested that the bands, with eight apostles only, might have been part of a bible cover or some other sacred object that survived from the treasury of the first king. The richly embroidered coronation robe, originally a chasuble, is, however, undoubtedly from St Stephen's court. The provenance of the other coronation regalia is diverse.

${ }^{20}$ For a summary of the different positions see Bertényi, Szent Korona, pp. 56-69, who concludes on the point that 'the secret of the Holy Crown is still unsolved'. Many historians date the assembly to the reign of Béla III ( I I 73-I I 96). Deér argued for I 270 when, on the death of Béla IV, his daughter Anna escaped with the regalia to Prague and Stephen V hastily assembled a new crown for his inauguration: Deér, Die heilige, pp. 256f. György Györffy has recently argued (on rather thin evidence) that the assembly took place under Coloman: István király és múve, Budapest, 2000, pp. 356-6r .

${ }^{21}$ See Szabolcs Vajay, 'A Szent Korona kamelaukion jellege', in Gyula Borbándi (ed.), Nyugati magyar tanulmányirók antológiája, München, i987, pp. $3^{\mathrm{IO}} \mathrm{-2}$ I. The reader may be spared from explication of these terms.
} 
The assembled diadem, as a whole, was up to I 790 held to be $\mathrm{St}$ Stephen's. At the coronation lunch of Emperor Leopold II as King of Hungary, scholars had a chance to discover the Greek inscriptions on the lower crown. But no proper examination of the crown was allowed either in I 790 or after. ${ }^{22}$ Thus, in the nineteenth century, the corona latina, the upper part of the jewel, was still held to be St Stephen's. Indeed it was regarded as tangible proof of the veracity of Hartvic's account of the crown's origin. In his Vita, Life of St Stephen, ${ }^{23}$ Bishop Hartvic, a century after the event, gave a colourful account of Bishop Ascherik's journey to Rome where he was sent by Stephen in the fourth year of his rule. The pope, acknowledging Stephen's work in establishing the Church in Hungary, granted him benediction, crown and apostolic cross. ${ }^{24}$ The crown donation by the 'pope' (Hartvic did not know Sylvester II by name), as described in this extremely popular work which attained papal approbation, ${ }^{25}$ was seen for centuries as an act which had established indissoluble ties between the Holy See and the kingdom, which underlined its independence from the German and the Byzantine emperors. In the nineteenth century, the crown donation thesis gave powerful support to the legal tenet that the Hungarian state had never been subordinated to any secular power; from its inception it possessed sovereignty.

The Sylvester crown donation did not look implausible to historians in the nineteenth century because of their views on the relationship between Pope Sylvester II (999-I003) and Emperor Otto III (983-I002). The young emperor who pursued an unrealistic dream, the renovatio imperii Romanorum, was not an equal match to the pope, his former teacher Gerbert, a highly educated skilful diplomat. ${ }^{26} \mathrm{He}$ must have been the crown's donor, so the argument continued, rather than Otto. The traditional mould into which the relationship between the two heads of Christianity had been pressed was broken by P. E. Schramm's seminal work published in 1929.27 Far from being an ineffective dreamer, Otto III re-emerged as a powerful designer of an

\footnotetext{
${ }^{22}$ Kelleher summed up all the physical examinations of the Holy Crown before I945: 'Those scholars who published the results of the brief investigations conducted under official auspices on the rare occasions when the Holy Crown was available for study, did so under pressure of the centuries-old tradition of sanctity, the aura of political significance surrounding the relic and a heritage of opinions, ecclesiastical and nationalistic, which engulfed the object.' Holy Crown, p. I 7.

${ }_{23}$ Scriptores rerum Hungaricarum, ed. E. Szentpétery, 2 vols, Budapest, I $937-38$ (hereafter, $S R H)$, second edn (reprint with addenda) by K. Szovák and L. Veszprémy, Budapest, I 999, 2, pp. $4 \mathrm{OI}-4 \mathrm{O}$.

${ }^{24}$ Ibid., pp. 4 I $2-I 4$.

25 C. A. Macartney, The Medieval Hungarian Historians: A Critical and Analytical Guide (hereafter, The Medieval), Cambridge, I953, p. I65.

${ }^{26}$ German historians were critical of Otto III for abandoning his predecessors' Sicherungspolitik as regards German interests for fantasy.

${ }^{27}$ P. E. Schramm, Kaiser, Rom und Renovatio, 2 vols, Leipzig, I 929 (hereafter, Kaiser).
} 
empire based on a universalistic ideal. Schramm reconstructed Otto's policy by the new titles his chancery introduced, particularly that of servus apostolorum, through which the emperor claimed a closer connection with St Peter than the pope. ${ }^{28}$ Further, Otto's renovatio strengthened the emperor's position as defensor ecclesiae. His mission was to reduce the barbarians to obedience and convert them to Christianity under his leadership, especially in the East. Schramm asked for a reappraisal of Otto's rule in the establishment of the Polish and Hungarian kingdoms. ${ }^{29}$ One of the several implications of his work was that the donor of Stephen's crown could not have been the pope alone.

Schramm broke an old mould without firmly establishing a new one. Among those who carried further his inquiry was A. Brackmann who, in his studies, reinterpreted the Polish and the Hungarian material. For him, Thietmar, the Bishop of Merseburg's almost contemporary reliable chronicle, offered decisive evidence in clearly stating that Stephen had received a crown 'through the favour and encouragement of the emperor'. ${ }^{30}$ Brackmann concluded that through 'staatliche Umgestaltung' Poland and Hungary were incorporated into the Empire by Otto III and that Boleslav and Stephen became imperial lieutenants, positions from which, however, both kingdoms soon afterwards escaped. ${ }^{31}$

Hungarian historians were put on the spot and a mighty row ensued. The debate took place against the background of the rising, expansionist Third Reich. A Hungarian historian, Zoltán Tóth (by no means a sympathizer with the new Germany), had the temerity to go along with Schramm and even Brackmann's findings. In a substantial study, ${ }^{32}$ prepared in 1937, he eliminated Hartvic's Vita, the main support for the Sylvester crown donation thesis, written around I I oo AD, from the proper sources on the establishment of the Hungarian kingdom. Composed a whole century after the event, Hartvic's Vita reflected the papal claims to supremacy in the investiture contest between the two heads of Christianity. Pope Sylvester II and Emperor Otto III, however, closely co-operated at the end of the tenth century and the Emperor's later separately by the author. The reliability of Hartvic's Life was questioned by Hungarian historians, notably by János Karácsonyi (Századok, I 892, p. I 36). In the I 930 , however, the doubts (until Tóth's work) disappeared. On Tóth, see Bertényi, Szent Korona, pp. 24-25.
} 
will was probably the decisive factor in granting the crown to Stephen. ${ }^{33}$ Alluding to the political conditions of Hitler's Central Europe, Tóth, aware of walking on to 'most dangerous terrain', ${ }^{34}$ claimed, nevertheless, that he was guided by what he believed to be the truth.

József Deér led the attack against Tóth's iconoclastic views. In a masterly argued long piece ${ }^{35}$ and in a Századok article Deér censured and taunted Tóth for blindly following (sometimes even misunderstanding) his German models. ${ }^{36}$ His primary target was the new outlook established by Schramm, Brackmann and the other German historians on Otto III. ${ }^{37}$ Their writings, Deér explained, were politically inspired; the universalistic imperial idea cloaked, as indeed it had even before Otto III, German hegemonic aspirations, the Reich behind the imperium. Once more the past was tied to the present:

The 1933 turning point did not only create the Third Reich but in close connection with this a new imperial idea. ${ }^{38}$

Deér went along with Schramm's German critics, who questioned whether Otto III's new titles, including the servus apostolorum, involved new claims. ${ }^{39}$ As to Brackmann's Umgestaltung, that the Hungarian kingdom was established under the protection of Otto III and that Stephen became a 'patrician' of the empire, the thesis lacked proper evidence. It disregarded the fact that the servus apostolorum title had appeared in the Pentapolis donation letter in January i oo I, only after the Hungarian coronation had taken place. ${ }^{40}$ At any rate, there was no evidence that the new title was ever used in connection either with Poland or Hungary. Hungarian historians had already questioned the

33 Tóth emphasized this even after his work was attacked by others, 'Történetkutatásunk mai állása' körül. A szent korona eredetkérdéséhez, Budapest, I 943 (hereafter, Történetkutatásunk), p. 36.

${ }^{34}$ Ibid., p. 5. Indeed it was 'dangerous terrain' during the Second World War. Brackmann, the leading authority of Ostforschung carried out a programme that served his political masters. He took care, for instance, that his study on the 'Umgestaltung' of Poland and Hungary (see note $3 \mathrm{I}$ above) should get to the desk of Reichsführer SS Himmler. Michael Burleigh describes the role played by Brackmann in the Third Reich in his Germany Turns Eastwards, Cambridge, i g88, esp. p. I 49.

${ }^{35}$ József Deér, 'A magyar királyság megalakulása', in A Magyar Történettudományi Intézet évkönyve, Budapest, I 942 (hereafter, 'A m. királyság'), pp. I-88. This work was also published in German and Italian.

${ }^{36}$ Deér, 'A m. királyság', pp. 3 n. 2, 26 n. 3, 4I n. I, 65 n. 7; 'III Ottó császár és Magyarország az újabb történetírásban' (hereafter 'III Ottó császár'), Századok, 78, i 944, pp. I-35 (pp. 26-27). Tóth called Deér's longer study a 'pettifogger's masterpiece which glosses over the crucial question all along', Történetkutatásunk, p. 2 I; Deér in his rejoinder protested against Tóth's personal attack which was grist to the mill of Romanian and Slovak historians whose aim was to damage the reputation of Hungarian historians, TII Ottó Császár', p. I 4 n. 39.

37 It is telling that Deér earlier was still sympathetic to the revision carried out by German historians on Otto III and the Pope's relationship. See his Pogány magyarság keresztény magyarság, Budapest, I 938 (hereafter, Pogány m.), pp. 94-99.

${ }^{38}$ Deér, 'III Ottó császár', pp. 8-9.

39 Deér, 'A m. királyság', pp. 56 and 6o-6 I; idem, 'III Ottó császár', p. I 3.

${ }^{40}$ Deér, 'A m. királyság', pp. 66-67. 
Vita's reliability as a historical source. ${ }^{41}$ There were, however, other sources, argued Deér, which supported the Sylvester crown donation, from which he then inferred his concluding point that Stephen as rex possessed sovereignty as an 'equal member in the community of European states'. ${ }^{42}$ Deér analysed the two other Lives of Stephen (in fact, Hartvic's sources) written in the late eleventh century. ${ }^{43}$ As neither of them contained anything on the donor of Stephen's crown, the historian had to apply heavy massage in arguing his case. Also, he had to construe an interpretation of a near contemporary source, generally reputed to be reliable, which his opponents exploited to the full and to which we have already referred.

The Chronicle of Thietmar, Bishop of Merseburg (c. I o I 5), contains the following passage:

Through the favour and encouragement [gratia et hortatu] of the Emperor

[Otto III], Waic [Stephen] the duke of Bavaria Henry's son-in-law, created bishoprics in his regnum, received crown and benediction. ${ }^{44}$

Thietmar's text was terse and obscure enough to be construed in ways which can lead to opposite conclusions as regards the donor of the crown; the exercise is entirely conjectural. Brackmann and Tóth could (and did) point out that the pope was not even mentioned by Thietmar and built on the phrase gratia et hortatu. Against this position Deér could argue that corona in the text appeared together with benedictio which only the pope could grant. ${ }^{45}$

In sum, it is more than probable that a crown was used at Stephen's inauguration as rex in $\mathrm{AD}$ I 000 (a crown that, however, did not

\footnotetext{
${ }^{41}$ The point was not backed by evidence, ibid., p. 3 n. 2.

${ }^{42}$ A rather anachronistic assertion, ibid., p. 88.

43 The Legenda minor S. Stephani regis (SRH, 2, pp. 393f) and the Legenda maior (ibid., pp. 377f.) were both written before or shortly after Stephen had been canonized in ro83 (see C. A. Macartney, The Medieval, pp. I6I-64). The Leg. minor does not even mention Stephen's crown, the Leg. major refers to his diadema regalis without any other particulars (SRH, 2, p. 384).

${ }_{44}$ Imperatoris (autem predicti) gratia et hortatu gener Heinrici, ducis Bawariorum, Waic, in regno suimet episcopales cathedras faciens, coronam et benedictionem accepit. Die Chronik des Bischofs Thietmar von Merseburg und ihre Korveier Überarbeitung, ed. Robert Holtzmann, Berlin, I 955, MGH Scriptores, Nova Ser., vol. 9, p. I 98.

${ }^{45}$ Deér, 'A m. királyság', pp. 26f. and 69-74.
} 
survive) ${ }^{46}$ It is less certain whether Stephen received a crown from abroad in a literal rather than only in a metaphorical sense. If, however, a diadem was actually sent to Hungary, this must have been with the complete agreement of the two heads of Christianity whose support Stephen undoubtedly enjoyed. The vexed question whether the pope or the emperor was the donor of the putative crown may not be (historically) the right one to ask. ${ }^{47}$ The question acquired importance because the driving force of the debate during the Second World War came from politics. The trouble is, however, that politics, in an insidious way, will always intrude on the historian's perspective. Today is no exception. Can the historian 'disremember', so to say, the uncanny 'parallels' between the Ottos' imperial plans and the EU's policy of eastward expansion? The revival of the Roman Empire in the West under Otto I by his coronation as emperor in AD 962 led to an expansion of Christianity in the East. Among those present in Quedlinburg at Easter 973 to pay homage to the emperor we find leaders and people of high rank from the new territories of Bohemia, Poland, Hungary and also Kiev and Bulgaria. ${ }^{48}$ Yet only some of those countries made the 'transition', to use a modernism (Brackmann's Umgestaltung). Bohemia soon became an integral part of the empire and then, in the year AD I ooo, Otto III went to Gnesen and Stephen was said to have received a crown: Poland and Hungary, too, were in some way connected with the imperial plan ${ }^{49}$ but not the other countries. As the attempt at integration into a universal empire turned out to be largely a fiasco, one should not perhaps make too much of the parallel that the countries that 'made' the transition at the end of the first millennium happen roughly to coincide in the second millennium with

\footnotetext{
${ }^{46}$ See József Gerics's study on the use of the 'Egbert Ordo' in Hungary in his 'Az úgynevezett Egbert (Dunstan)-ordo alkalmazásáról a XI. századi Magyarvországon', in György Székely (ed.), Eszmetörténeti tanulmányok a magyar középkorból, Budapest, I984, pp. 243-54 and Benda and Fügedi, Stephanskrone, pp. I 5-I 7. Pope Gregory VII in a letter to King Salamon (28 October I 074) recalled that a lance and a crown, the insignia of the regnum, were (after the Battle of Ménfó in I 044) sent to the tomb of St Peter whence his dignitas originated. There is no agreement among historians whether these were Stephen's regalia or not. The Pope in another letter ( 13 March I075) sent to Géza I reminded the king that Hungary, like other kingdoms, was subordinated only to the universal Roman Church rather than to other kings: Vilmos Franknói, Magyarország egyházi és politikai összeköttetései a római szent-székkel), 3 vols, Budapest, Igo I-O3 (hereafter, Magyarország), pp. 23, 24, and 360. Gregory VII's claims of spiritual and political papal supremacy were not yet made by popes at the beginning of the eleventh century.

47 Whoever sent the (putative) crown, Hungarian historians rightly point out the complete lack of evidence that Stephen accepted imperial overlordship. Indeed he stressed his independence on every occasion. See, for example, Pál Engel, The Realm of St Stephen, London and New York, 200 I (hereafter, The Realm), p. 28.

${ }_{48}$ Magyarország története, ed. Pál Zsigmond Pach, 9 vols, Budapest, I 976-85 (hereafter, $M T)$, I, p. 729.

${ }_{49}$ Poland and Hungary were compared in the light of recent literature by János M. Bak in 'Some recent thought of historians about Central Europe in I ooo A.D.', in Hortus Artium Medievalium, 6, 2000, pp. 65-7 I.
} 
those of the so-called Visegrád group: the front-line applicants to join the European Union.

\section{The cult of St Stephen's Crown}

Hungary emerged from the transformation as a recognized independent kingdom. From a half nomadic pagan society, it became a Christian regnum with a settled rural population. This momentous change was rightly associated with the country's first king, Stephen (997-1 038). He established the Church by creating bishoprics, ruled as dominus over his regnum, organized the system of royal counties headed by ispáns (comites) and set up the high offices of his court. Although the two lawbooks bearing his name may have been compiled some years after his death, Stephen was venerated for centuries as the lawgiver. Property, privileges, rights (liberties) and obligations were recognized throughout the Middle Ages as deriving from the auctoritas of the first monarch. ${ }^{50}$ With papal permission he was canonized in $1083^{51}$ under King Ladislas I, who likewise was canonized in I I 92. The canonization led within the ruling dynasty (the so-called 'St Stephen's clan') to the cult of sancti progenitores nostri in the thirteenth century. The szentkirályok (saintly kings) label, as József Deér argued, combined Christian and pagan charismata and was frequently applied to the whole dynasty rather than only to its canonized members. ${ }^{52}$ The saintly clan was believed to have been endowed with supernatural powers. Sacral rulership as an ascribed quality of the dynasty is a well-known feature

\footnotetext{
${ }^{50}$ On the founder's role in Europe and Hungary see Ferenc Eckhart, 'Jog és alkotmánytörténet', in Bálint Hóman (ed.), A magyar történetírás új útjai, Budapest, I93 I (hereafter, 'Jog és alk.tört.'), pp. 269-320 (p. 285); Péter Váczy, A szimbolikus államszemlélet kora Magyarországon, Budapest, I 932 (hereafter, Szimbolikus), pp. 37-38, 54-55.

${ }^{51}$ King Stephen I was canonized together with Emeric, his predeceased son and three martyrs of the Church: Bishop Gerard (Emeric's tutor, later ordinarius at Cisanád) and two hermits, Zoerard and Benedict. Stephen's body was disinterred and was found intact. The Holy Dexter (only the hand has survived) has ever since been venerated as a relic of the 'saintly king' (szentkirály). It is kept today in the Budapest Bazilika church in a glass cage and taken around the town in a splendid procession on St Stephen Day, 20 August.

${ }^{52}$ See Deér, Pogány m., ch. 4; Emma Bartoniek, 'A magyar királyválasztási jog a középkorban', Századok, 70, I936 (hereafter, 'A m. királyválasztás'), p. 365 and n 2; Gyula Kristó (ed.), Korai magyar történeti lexikon, Budapest, I 994, pp. 632-33 incl. literature; Gábor Klaniczay, Holy Rulers and Blessed Princesses: Dynastic Cults in Medieval Central Europe, Cambridge, 2002, esp. chs 3 and 4 .
} 
of kingship in early medieval Europe. ${ }^{53}$ But how the insignia of the rulers became sacred is only a matter of conjecture.

Stephen's inauguration followed the general European custom of instating people into office with objects which testified to the authority behind the post. ${ }^{54}$ From the teaching of the Apostle that all legitimate power derived from God's authority ${ }^{55}$ it followed that the emblem which conferred officium and dignitas was presented to the appointed by the Church. The investiture took place at the altar and was rather similar to the consecration of a bishop; grace was transferred to the king from God by virtue of which he became Christ's deputy on Earth. The aureole attached to the incumbent szentkirály and the office was then gradually transferred to the insignia associated with the whole clan.

The peculiarity of the Holy Crown tradition in Hungary is that although the holiness of the visible crown (as we shall presently see) appeared later, the tradition went deeper and lasted much longer than it did elsewhere in Europe. The crown had already acquired prominence in the West among the insignia (orb, sceptre, sword, etc.) in transferring officium and dignitas by the time kingship was established in Hungary. There, too, the crown rather than any other regalia stood for rex, ${ }^{56}$ although at Stephen and his immediate successors' inauguration acclamatio and anointment were possibly still more important than coronation. ${ }^{57}$ It is more probable that the regalia used at Stephen's

\footnotetext{
${ }^{53}$ Janet Nelson notes: 'English seems to be the only language which not only distinguishes sacral from sacred, but (unlike Greek, Latin, French or German) also has two separate words for the substantive saint and the adjective holy (or sacred). Sacrality involves the transmission of otherworldly powers into this world, crosscutting the line between nature and supernature. Sacral rulership, therefore, transcends the distinction between clerical and secular (in societies where such a distinction is made at all). It constitutes an ascribed not an achieved status, for its bearer possesses magical powers by definition. Nothing has to be proved or approved: sacrality goes with the job, is carried in the blood. There was nothing here to attract, and much to repel, the Christian churchman attempting to construct a model of royal sanctity.' Janet L. Nelson, Politics and Ritual in Early Medieval Europe, London, 1986 (hereafter, Politics and Ritual), pp. 7 I-72.

54 On the sources of royal coronation in Hungary see János M. Bak, Königtum und Stände in Ungarn im I4-I6. Fahrhundert, Wiesbaden, 1973 (hereafter, Königtum), Anhang II, pp. I65-90; Benda-Fügedi, Stephanskrone, pp. 4I-48.

${ }_{55}$ Epistle to the Romans, I 3.I, and see Emma Bartoniek, 'A királyi hatalom eredetéről', Századok, 7o, i936, pp. 480-96.

56 According to the Chronicle, Duke Béla, summoned to Várkun by King Andrew I after I 057 to test the loyalty of his brother, had to choose between the 'sword' (ducatus) and the 'crown' (si vis regnum, accipe coronam, si ducatum, accipe gladium), SRH, I, p. 355.

${ }^{57}$ The Legenda maior distinguishes three elements in Stephen's inauguration: acclamatio, uncio and coronatio in that order, $S R H, 2$, p. 384 . The seating of the king in the throne of the founder king was also a part of the investiture held in the Basilica at Székesfehérvár. On European practices see János M. Bak (ed.), Coronations, Medieval and Early Modern Monarchic Ritual, Berkeley, CA, and Oxford, I990. The editor pointed out that research in the previous decades 'raised the study of royal ritual from the marginal and illustrative to the paradigmatic', p. 6.
} 
inauguration served his successors. ${ }^{58}$ The authenticity of royal power was conserved by being linked to the founder. ${ }^{59}$ The claim that the diadem used at coronations came from the founder of the kingdom, the szentkirály (saintly king), strengthened the sanctity of his successors. The crown itself did not belong to the incumbent but to the ruling clan, the whole dynasty. ${ }^{60}$ Yet the term sacra corona appeared for the first time in a royal charter only in I 256 , long after the phrase had gone out of use in other European countries. ${ }^{61}$ The 'holiness' of the crown indicates that it was not merely a symbol, for that presupposes a distinction between the representation and what is being represented. But the clear distinction between the jewel and what it stood for developed only in more recent times. ${ }^{62}$ The 'strength' or 'mystery' attributed to the Holy Crown, the object itself, reveals the lack of distinction. ${ }^{63}$ This is the critical point: to wit, until modern times the visible crown did not symbolize some abstract idea, like the 'state', as is frequently claimed; the material object itself was believed to possess efficacy.

Andrew III (I 290-I 30I), the last of the native dynasty, was the first king who claimed in a royal charter in 1292 that he was 'wearing' St Stephen's Crown. ${ }^{64}$ The king must have referred to the crown that has survived unless all experts in the dating of its assembly are mistaken. ${ }^{65}$ The growing political importance of the crown from the second half of

\footnotetext{
58 The Chronicle recalls that Peter's (second) inauguration in ro44 took place sacris insignibus sancti regis Stephani, SRH, I, p. 333.

${ }^{59}$ Andrew I, I $446-$ I 060 (who had the hard job of claiming continuity with Stephen) imitated the founder even by the coins he minted and the seals of his summons: Deér, Pogány $m$. , p. I I 5 .

60 St Stephen's successors even from I 046, when Andrew I replaced Peter, were not the descendants of the first king but his uncle, Michael.

${ }^{61}$ Ferenc Eckhart, A szentkorona-eszme története, Budapest, i94 I (hereafter, Szentkorona), p. 42; Benda and Fügedi, Stephanskrone, pp. 26-3I; Tamás Katona (ed.), A korona kilenc évszázada, Budapest, I 979 (hereafter, Korona), pp. 48, 53-55.

${ }^{62}$ For foreign analogies see Ernst H. Kantorowicz, The King's Two Bodies, Princeton, NJ, I 957 (hereafter, The King's), pp. 338-4I.

63 Although references to robur and mysterium appeared first time in I 440: see below.

${ }^{64}$ Tóth, Hartvik-legenda, p. I 26; Benda-Fügedi, Stephanskrone, p. 29. Strictly speaking, kings did not 'wear' St Stephen's Crown which was used only at their inauguration and not otherwise. Nor is there evidence that it was worn at coronamenta. The kings appeared in images wearing either a simple circlet or a lilied crown: Deér, A m. királyság,, pp. I 7-ı 8. Benda and Fügedi, Stephanskrone, pp. 55-56.

${ }^{65}$ The first description of St Stephen's Crown is, however, available only from I 440 in the mortgage-deed by which Elizabeth, widow of King Albert, pawned the crown to Frederick III for 2,500 florins. Emma Bartoniek describes the political background in her $A$ magyar királykoronázások története, Budapest [ i 939] (hereafter, A m. királykoronázások), pp. 64-65.
} 
the twelfth century is indicated by references to its custody. ${ }^{66}$ Possession of St Stephen's Crown became vital in the struggle for the throne between rivals: on the first of many future occasions, in i i 63 , the crown was stolen. ${ }^{67}$ In I 30 I a new chapter began in the history of the Holy Crown which, with the extinction of the native szentkirályok clan in the male line, brought to life its peculiar Hungarian features. The cognate branches generated plenty of foreign claimants ${ }^{68}$ and from this time, and for well over two centuries, succession crises became the norm. Now coronation with St Stephen's Crown became constitutive in legitimizing the position of the incumbent. Charles Robert, the Angevin claimant to the throne, was crowned by his party in I 30 I and once again in I 309 with 'substitute' crowns blessed by the pope. Yet he could settle in office only after he had secured the possession of St Stephen's Crown and was inaugurated for the third time on 20 August I 3 I $\mathrm{cum}$ corona sancta. ${ }^{69}$ King Matthias, who acceded to the throne in January I $45^{8}$, in order to consolidate his position was made to pay through the nose by Emperor Frederick III, to whom he was also forced to make political concessions, in order to recover from him the Holy Crown with which Matthias was crowned in March $1464 .{ }^{70}$ Thus, in late medieval Hungary, the liturgy of the coronation with the Holy Crown acquired new, fundamental significance, even though the king's consecration had elsewhere become (as Archbishop Thomas Cranmer observed) 'but a ceremony', having 'its ends and utility yet neither direct force nor necessity'. ${ }^{71}$ In most of Europe but not in Hungary, then, liturgy was gradually replaced by the dynasty-bound divine right. ${ }^{72}$

In fourteenth-century Hungary, instead, the belief evolved that the crown had heavenly origin: ab angelo privaretur, and as such was

\footnotetext{
${ }^{66}$ The custody of the crown was a politically most sensitive job. Under the Árpáds the custos of the Basilica at Székesfehérvár, the centre of St Stephen's cult, was the keeper. From the fourteenth century the crown was kept by the king in the safe castle of Visegrad, later in Buda Castle. From I 464 onwards the diet introduced measures for the protection of the Holy Crown which eventually led to the system that has survived into the twentieth century: the two Keepers of the Holy Crown elected by the diet. Bertényi, Szent Korona, pp. 62 and 78f.; Benda and Fügedi, Stephanskrone, pp. 53-55.

67 An incident in I r 63: see Bertényi, Szent Korona, pp. 6o-62.

${ }^{68}$ Vilmos Franknói, A magyar királyválasztások története, Budapest, I 92 I, p. 25.

${ }^{69}$ SRH, I, p. 486; Bak, Königtum, pp. I $3^{-22}$ (the full story); Benda-Fügedi, Stephanskrone, pp. $33-4$ I.

Benda-Fügedi, Stephanskrone, pp. 77-89; Engel, The Realm, pp. 299-300.

${ }^{71}$ Quoted by Nelson, Politics and Ritual, p. 283. The high degree of institutionalized government turned royal succession in western Europe 'automatic'. When George VI suddenly died in London in $195^{2}$ Princess Elizabeth happened to be on safari in Kenya on a treetop. As a courtier old hand observed: 'Elizabeth had climbed up a tree as Princess and climbed down as Queen Elizabeth II'.

${ }^{72}$ Kantorowicz, The King's, pp. 3 I 7-1 8 and 328-30.
} 
inamissible, not liable to be lost. ${ }^{73}$ Cardinal Gentilis di Montefiori, papal legate plenipotentiary threw up his hands in despair in I309 because the Hungarians treated St Stephen's Crown, the visible crown, with so much veneration, attributing to it such authority quasi in eo sit ius regium constitutum. ${ }^{74}$ That just about summed up the position. There was, nevertheless, in 1440 a reckless attempt to undermine the traditional belief. The diet elected Vladislav I king, but St Stephen's Crown was abroad in the hands of the rival party. The king's supporters decided to use as a substitute for the coronation the relic crown taken from St Stephen's sarcophagus at Székesfehérvár. The diet declared that 'the coronation is always dependent on the will of the people (regnicolae) and that the efficacia et virtus corone rests on their approval'. Should it be impossible to retrieve the old crown, its mysterium et robur would be transferred to the new crown. ${ }^{75}$ The innovation, bordering on sacrilege, ended in well deserved failure. Vladislav I was dead before the Holy Crown had been recovered and none of his donation letters were recognized in court. ${ }^{76}$ The mystery of St Stephen's Crown remained unimpaired. Visitors from the West were mystified about the office attributed to a jewel. The Italian Bonfini, King Matthias's court historian, writing in I 495 (and repeated by others even in the late seventeenth century), preserved Mihály Guti Országh, the palatine's injunction that 'even an ox, once you see it embellished with the Holy Crown, must be honoured with respect and treated as inviolate saintly king'. ${ }^{77}$

The palatine could not have quite meant it, otherwise we would not be able to explain that in the anarchic political conditions that followed

\footnotetext{
${ }^{73}$ In I 305 during Otto's travel to Hungary to be crowned king, the Holy Crown fell out of its case on to a busy road, yet only his men found it next day (others could not see it) which according to the Chronicum Pictum 'Quid est, quod a nullo inventa, sed ab ipsis, qui portabant, nisi quod ne Pannonia data sibi corona ab angelo privaretur'. SRH, I, p. 484.

74 'cui multum reverentie atque auctoritatis ex dicti regni incolarum opinione defertur, quasi in eo sit ius regium constitutum.' Letter to the Pope, 29(?) June I 309, Buda in Acta legationis Gentilis, Monumenta Vaticana hist. Regni Hung. illust., Ser. I, I887-9I, vol. 2, pp. lxx, lxxx-lxxxi, 353; Bartoniek, 'Corona és regnum' (hereafter, 'Corona'), Századok, 68, r 934 , p. $32 \mathrm{I}$.

${ }_{75}$ Martinus Georgius Kovachich, Vestigia comitiorium apud Hungaros, Buda, I 79o, p. 240. The passages were quoted by Eckhart, Szentkorona, pp. 96-97; Bartoniek, 'Corona', p. 325.

76 Werbőczy, in withholding recognition to Vladislav's charters, observed: 'qui non vera, sacraque regni hujus corona, sed reliquiarum capitis S.Stephani regis ornamento insignitus fuerat': István Werbőczy, Tripartitum opus juris consuetudinarii inclyti regni Hungariae, editio princeps: Syngrenius (hereafter, Tripartitum), Vienna I 5 I 7 , repr. Márkus edn of Corpus Juris Hungarici, Budapest, I 897 (hereafter, C7H), Pt. II, Tit. I4, para. 34. See, also, Péter Révay's points on this question, Keeper of the Holy Crown and author of the first history of the jewel from i6 13 , in Katona, Korona, pp. 33 I-32.

77 Quem cunque sacra corona coronatum videris, etiam si bos fuerit, adorato et pro sacrosancto rege ducito et observato. Antonii Bonfinii, Rerum Ungaricarum decades quatuor cum dimidia Basileae, ex officina Oporiana, I 568, Dec. 4, Lib. 3, p. 588. The bon mot was probably a sneer at Vladislas II. See György Szerémi, A mohácsi vész kora, Szeged, I 94I, pp. 25, 27 , 30 .
} 
the disaster at Mohács in ${ }_{1} 526$ the ország elected, at two diets within a year, János Zápolya and Ferdinand I Habsburg. Both kings' coronations took place in traditional form with St Stephen's Crown at Székesfehérvar, officiated by the same István Podmaniczky, the Bishop of Nyitra. ${ }^{78}$

All the same, the authority of St Stephen's Crown, if anything, acquired new significance during the reign of the Habsburg dynasty. The diaetalis coronation, with the Oath and with bargaining which preceded the issuing of the Inaugural Diploma, offered the best institutional safeguards to the nobility against the encroachments of the alien monarch. ${ }^{79}$ The transparent utility and rational function of diaetalis coronation did not, however, weaken the supernatural attributions of the emblem even in the eighteenth century. József Keresztesi, a Protestant parson, recorded the violent storm that suddenly engulfed the whole country when, on the order of Emperor Joseph II, the Holy Crown was taken from Pressburg Castle to the Schatzkammer in Vienna in I 784. ${ }^{80}$ People there were convinced that God had punished them with economic miseries for the emperor's daring act. It would be a mistake to assume that by the late eighteenth century only the uneducated attributed supernatural powers to St Stephen's Crown. On the command of Emperor Joseph, the Staatsrat instructed the University of Pest to revise a textbook MS in I 785 on Hungarian Public Law to 'explain the rights derived from the alleged sanctity of the crown as state-rights' ${ }^{81}$ In late February I 790 the regalia were brought back to Buda amid, even by Hungarian standards, great pomp and splendid celebrations. The counties set up banderia for the crown's 'protection'. The Holy Crown was addressed as if a 'person' in speeches, poems and songs. ${ }^{82}$ Law VI of $\mathrm{I} 790$, in making provisions about the keeping of the royal emblem in Buda, observed that the Holy Crown, which had faced great perils, nonnisi superum favore servatam. The innovations of Joseph II, 'the hatted king' so called as he dodged his coronation, incurred the

\footnotetext{
${ }_{78}^{78}$ Bartoniek, A m. királykoronázások, pp. 85-91.

${ }^{79}$ For the text of the inaugural Diploma, see Henry Marczali, Hungary in the Eighteenth Century, Cambridge, ig io (hereafter, Hungary), pp. 348-52.

80 József Keresztesi, Krónika Magyarország polgári és egyházi közéletéböl, Pest, I 868 (hereafter, Krónika), pp. 82-83 and 197; for an account of Joseph's measure see Henrik Marczali, Magyarország története II József korában, 3 vols, Budapest, I 885, 2, pp. 363-69; see also Éva H. Balázs, Hungary and the Habsburgs I 76 5-I800, Budapest, I 997, pp. 204-05.

${ }_{81}$ Ferenc Eckhart, A jog-és államtudományi kar története, Budapest, I936, (hereafter, A jogi kar tört.), p. I 5o; Keresztesi, Krónika, p. I 98.

${ }^{82}$ Ibid., pp. I 96-203, 2 I 4; Keresztesi apparently examined 'the so-called' Holy Crown, described in his diary (he knew that it could not be Stephen's) and was surprised by the 'superstitio' that surrounded it (pp. 269-75); Benda-Fügedi, Stephanskrone, pp. I64-78; Bertényí, Szent Korona, pp. I 25-28.
} 
same fate as happened to the charters of Vladislav I. ${ }^{83}$ The cult of St Stephen's Crown, as E. H. Kantorowicz alluded to it, created such a robust tradition of continuous and legitimate political authority that there was no need (indeed no room) for abstractions like the theory that 'the king never dies', or that the king possessed two bodies, a physical and a political. ${ }^{84}$

The Enlightenment and nineteenth-century liberal constitutionalism dented the belief in the sacred character and mystery of the crown jewel. Through gradual and incomplete change, St Stephen's Crown became a symbol of the values and fundamentals rather than, as earlier, a carrier of them. The coronation with the crown, however, retained its constitutive force up to the end of the Monarchy. Elsewhere it may have become a ceremony but in Hungary, insisted Ferencz Deák, coronation was constitutionally essential..$^{85}$

As in earlier centuries, the Crown of St Stephen has continued to show a remarkable narrative even in the more recent periods. Because the visible crown was indispensable in legitimizing political power at times of impending regime change, the crown habitually disappeared from Buda Castle where from I790 it had been kept. In I 849, the crown travelled three times. In January it was taken to Debrecen to avoid the army of Prince Windisch-Graetz. It was returned to Buda after Görgei had retaken the city in May. In late August, when the War of Independence was lost, Prime Minister Szemere, before escaping to the Ottoman Empire, buried the chest of regalia in swampy ground at the borders. It took over four years for the Austrian authorities to find the chest. ${ }^{86}$ The coronation of Francis Joseph in I 867 combined the inauguration of the constitutional regime with a formidable display of pageantry. The last coronation, that of Charles IV in I9i6, was a subdued occasion. The crown tilted (megbillent) on Charles's small head

\footnotetext{
${ }^{83}$ The derisory nickname of kalapos király became in I 78 I the title of the Pauline monk Pál Ányos's manuscript poem: Lóránt Czigány, The Oxford History of Hungarian Literature, Oxford, I984, p. 90; Béla Tóth, Szájrul szájra, Budapest, I 90 I (hereafter, Szájrul), pp. 7 I-72. Joseph II's ordinances were not recognized by the courts, and see note 76 above.

${ }^{84}$ Kantorowicz observed that 'Hungary carried the distinction between the mystical crown and a physical king to great refinement, but the material relic of the Crown of St Stephen seems to have prevented the king from growing his own super-body', The King's, p. 446 .

${ }_{85}$ 'The coronation is constitutionally essential' wrote Ferencz Deák: Ein Beitrag zum ungarischen Staatsrecht (hereafter, Ein Beitrag), Pest, I865, pp. 207-08. Also, Deák Ferencz beszédei, ed. Manó Kónyi, 6 vols, second edn, I897-1903 (hereafter, DFB), 3, p. 554, the text of the Address of February i 866. The coronation with the Holy Crown in the course of which the neorex takes the Oath and on his inauguration issues the Diploma provided the indispensable guarantees for the constitutionality of monarchic rule. Deák insisted that the Diploma was not ordinary law: the issuing of it, before the coronation, was a duty: Ein Beitrag, pp. I $57-58$.

${ }^{86}$ Benda-Fügedi, Stephanskrone, pp. I8 I-97.
} 
and within two years his kingdom and empire were dissolved. ${ }^{87}$ In October I 944 the Regent, Admiral Horthy, ordered the crown to be buried. The fascist successor regime dug it up and Szálasi took the oath facing it. Not long afterwards the chest of regalia began its long journey, this time to the West, to escape capture by the advancing Red Army. Once more, the crown was buried in Germany. The US authorities dug it up whereafter its whereabouts were uncertain for many years. In fact, the chest was kept at Fort Knox until January I 978 when the US government handed back the regalia to Hungary. ${ }^{88}$ There is no mistake: the Crown of St Stephen is inamissible.

The visible and the invisible crown compared ${ }^{89}$

Enough has been said to demonstrate that the Crown of St Stephen has engendered a singular and enduring national tradition. The visible crown of Hungary has been surrounded by an unambiguous cult from medieval to modern times. The constitutional function of the visible crown can also be properly attested through legal evidence. There is plenty in the lawbook on the visible crown: how and where it was to be guarded, about its elected Keepers and about the coronation itself. In contrast, the invisible crown, the ideas associated with the Holy Crown, apart from some territorial uses, partly based on the medieval precept of inalienability, only rarely appear in the lawbook. Indeed, the primary context of the invisible crown has always been political rhetoric rather than constitutional law. Any attempt to summarize the history of the invisible crown, so far as it may be separated from the visible one, is like trying to put a ferret into a bag. The subject is complex and highly controversial. The last work on it, based on original research, was published over sixty years ago by Ferenc Eckhart. ${ }^{90}$ In contrast to the visible crown, which has attracted much scholarly interest, very little research has been done on the invisible crown since Eckhart's book. This study will lean heavily on the knowledge that went into it. Eckhart took for granted that because the past and the present were always

\footnotetext{
87 Alice Freifeld, Nationalism and the Crowd in Liberal Hungary, I848-I9I4, Washington, D.C., 200o, pp. I89-92 and 2 I 4-ig offers a vibrant account of the coronation on 8 June I 867; Benda-Fügedi, Stephanskrone, pp. 2 I 8-2 I; Bertényi, Szent Korona, pp. I 37-4 I .

88 Benda-Fügedi, Stephanskrone, pp. 226-32.

${ }^{89}$ For general points, see Kantorowicz, The King's, pp. 336-42; Sándor Radnóti observes that in contrast to Western Europe, where institutional continuity was secured by the invisible crown, in Central and Eastern Europe 'the visible crown provided continuity', 'Az üvegalmárium, esettanulmány a magyar korona helyéről', Beszéló, III. Ser. 6, November 200 I (hereafter, 'Üvegalmárium'), p. 49.

90 Eckhart, Szentkorona; for a good summary of this basic study, see Josef Karpat, 'Die Idee der Heiligen Krone Ungarns in neuer Beleuchtung' (hereafter, 'Die Idee') in Manfred Hellmann (ed.), Corona regni, Darmstadt ig6 i (hereafter, Corona), pp. 349-98. Ferenc Eckhart, born in $\mathrm{i} 885$, was Professor of Legal and Constitutional History in the Law Faculty, Budapest from i 929 to i 957.
} 
mixed up in 'crown' uses, the tradition had to be studied as a whole. The question that primarily interested Eckhart was about continuity versus discontinuity. That was entirely justified. It would be a grave (yet in practice very common) error to assume that the historian's job is to unravel the 'development' or history of the Holy Crown 'idea'91 sub specie aeternitatis, as it were. ${ }^{92} \mathrm{I}$ find such an assumption manifestly untenable. A patently multivocal term, only as such is the 'crown' an appropriate object of study. Accordingly, what follows here will be an attempt to distinguish the different classes of corona uses (from age to age), establish the provenance of new ones, where serviceable, explain their context and discard attributions to the crown that are patently anachronistic. The exercise may shed some new light on the nature of the Holy Crown tradition. Sixty years is a long time (the past, as we all know, is a different country). I take assumptions, different from Eckhart's; I see distinctions at places elsewhere than he did. These differences undoubtedly have a bearing on my conclusions. For all this, the inspiration to pursue this study came from his work.

\section{Rex and corona: the incumbent and the institution}

As it appeared in the Hungarian sources in the eleventh century, corona, by far the most prolific multivocal political term in the country's history, was clearly an adaptation from contemporary Christian political theology in which its uses usually appeared in association with a jewel. We have already seen that the term in Hungary, as in other countries, stood for the gold rim embellishing the king's head with the function of transferring the spiritual and material powers of royalty. Upon this primary sense of corona stood a whole cluster of uses: it appeared as the royal dignitas associating the notions of rank, prestige, and honour; also as that of officium associating capacities, i.e., properties and competencies of power in its material appearance. ${ }^{93}$ Further, since earthly capacities were blended with transcendental ones in the inauguration, corona associated the spiritual capacities of kingly power. More widely, corona conveyed everything that was consecrated by the Church as belonging to the king's vocation and even his character qua

\footnotetext{
91 'a szentkorona eszme'; Ferenc Eckhart, notwithstanding his book's title, was probably aware that it was a misnomer or at least a malapropism.

92 The assumption of the Holy Crown 'idea' frequently leads to the patently anachronistic corollary that the crown has symbolized the 'Hungarian State'.

${ }_{93}$ Most of these uses are not yet based on clear distinctions. Rex and corona or dignitas and officium are not juxtaposed, they are close cognates if not synonyms of each other in the legends, in King Stephen's Admonitiones and in the early chronicles: Bartoniek, $A \mathrm{~m}$. királykoronázások, pp. 67-69; SRH, 2, pp. 62 I-24; Josef Karpat, 'Corona regni Hungariae in Zeitalter der Arpaden' (hereafter, 'Corona') in Hellmann, Corona, pp. 225-348 (transl. from Slovak, Bratislava i 937); Eckhart, Szentkorona, pp. I $3^{- \text {I }} 7$.
} 
king. Finally, corona denoted kingship in general, insofar as an abstraction like this could exist in the eleventh century.

These uses of corona, interwoven with purely religious ideas, appear in the legends, in early Hungarian chronicles and similar writings. Sense and context are frequently not easily definable, a characteristic of Christological thought taken over to the political writings in liturgical kingship. In the Admonitiones ${ }^{94}$ two crowns occur: Stephen's terrestrial, and therefore temporal corona, meaning a jewel and also a holder of certain qualities, and a celestial and therefore eternal corona as the apotheosis of saints. ${ }^{95}$ The holiness and glory of the former are sometimes contrasted, at other times not really distinguished from the celestial bliss and sanctity of the latter. The king serving God faithfully through his terrestrial corona will eventually be worthy of the other, the celestial corona. If he wants 'to keep the royal corona in honour's6 Stephen tells his son - he should retain the Christian faith: without that he would neither be able to reign in honour nor would he share in the 'eternal kingdom or corona' ${ }^{97}$ Emeric is told to augment the Church's properties so that his corona may be praised. ${ }^{98} \mathrm{He}$ is to mete out justice, this being 'the [fifth] ornament of corona' ${ }^{99}$ Hospites adorn the court, says the author, so if they are patronized by the king '[your] corona will be held in esteem by everybody'. ${ }^{100}$ The spirit of disobedience 'disparages the leaves of corona'101 — said at another place. Again: 'The degree of virtues defines the king's corona.' ${ }^{102}$ At the end of the work Stephen declares that royal corona is 'compounded by the discussed principles'. ${ }^{103}$ All in all, the function of corona in the Admonitiones is to demonstrate the substance of kingly power. The term embraces the

${ }^{94}$ Libellus de institutione morum, SRH, 2, pp. 61 9-27; King Stephen's Admonitiones to his son Emeric: Bartoniek, 'Corona', pp. 3 I 4 f.

95 The roots of the crown concept of the Admonitiones as being based on the European Christological literature is discussed by József Balogh in his 'Szent István politikai testamentuma', Minerva, 9-10, I930, pp. I 29-64, and I93 I, pp. 39-5 I; also in his 'Szent István “intelmei”-nek forrásai', in Cardinal Primate Jusztinían Serédi (ed.), Emlékkönyv Szent István halálának kilencszázadik évfordulóján, 3 vols, Budapest, I 938 (hereafter Emlékkönyv), 2, pp. 237-65 and esp. p. 262, Jenő Szűcs, 'König Stephans "Institutionen", , in Nation und Geschichte, Budapest, I 98 I, pp. 245-62.

96 'Si regalem cupis honestare coronam.' $S R H, 2$, p. 62 I.

97 'nec eterno regno vel corona participantur.' Ibid. Also, 'Hec omnia superius libata regalem componunt coronam, sine quibus vallet nullus hic regnare, nec ad eternum pertingere regnum.' Ibid., p. 627. Bishop Hartvic writes of God '... ille nimirum potius electum sum Stephanum hac (temporali) statuerat felicitier insignire corona, ipse postmodum eundem felicius decoraturus eterna'. Life of St Stephen, ibid., p. 4I 3.

${ }^{98}$ Ibid., p. 622 (26)

99 '. . quinta regalis corone est ornatio.' And again, 'ut tua corona laudabilis sit et decora'. Ibid., p. 624 .

100 'tua corona ab hominibus habeatur augusta.' Ibid., p. 625.

101 'Spiritus quidem inobedientie dispergit flores corone.' Ibid., p. 626

102 'Modus virtutum finit coronam regum.' Ibid., p. 627.

103 Ibid. For other examples see Balogh's works in note 95. 
duties of the king, the qualities the holder of the office ought to have, and also the principles of rule to be followed.

Most of these uses of corona were close to rex; however, none were merely identical with it. The terms rex and corona, though in none of the available sources of the eleventh century are they juxtaposed, stand for more than rhetorical tautology. ${ }^{104}$ Corona was, even in the eleventh century, distinct from rex. The use of both terms did not reflect a functional differentiation between man and his office, although this idea could have been known in Hungary at that time. Nor was the use of the two terms related to any distinction between officium and dignitas, these being close cognates if not synonyms at the time.

Rex usually embraced the king both qua king and also qua human being. It seems, however, especially in the Admonitiones, that rex sometimes means only the latter and that the more spiritual corona tends to cover kingship. ${ }^{105}$ It looks plausible that this was so. King Stephen (Vajk) inherited power from his father Geiza - a pagan - and the future king himself had been converted to Christianity in his youth. The king's person, therefore, could not alone represent all the new qualities attached to Christian rulership. The qualities set out for the king to practise pertained to corona: rex, the officium in its ideality. So corona in the eleventh century was distinct only from rex as human being and that only by implication; no explicit contrast was made between them as yet. Corona, of course, belonged entirely to the king. It was his in the sense that it was conferred upon him by the Church on behalf of both pope and emperor to the exclusion of everybody else.

Corona, when it appeared in Hungary, implied a reference to a higher authority. ${ }^{106}$ The grace of God was transmitted through it to the king and so the distinction between rex and corona was already beginning to appear. It was, however, insufficient as yet for the emergence of a consistently dichotomous use of rex and corona. As the person of the king and his dignitas were connected, royal charters referred to the honor, gloria, commodum, incrementum of the crown, and likewise its preiudicium, detrimentum or opprobrium. ${ }^{107}$ These uses did not yet separate corona and rex. Soon, however, the rights, duties, properties and capacities as they gradually evolved as parts of the royal office, became attributes of corona, a process by which the term became filled with positive content. As the capacities and competencies of the royal office differentiated, so

\footnotetext{
104 This does not mean, however, that the distinction was already clear either. Kantorowicz (The King's, p. 345) writes about the distinction between king and crown found in Glanvill's De legibus et consuetudinibus regni Angliae, although here the institutional framework was undoubtedly more differentiated than in Hungary.

105 Bartoniek, 'Corona', pp. 3 I 4-i 7.

106 Eckhart, Szentkorona, pp. I4-I 5 .

107 Karpat, 'Corona', pp. 3 I 2-23, passim; Eckhart, Szentkorona, p. 43.
} 
did the senses and contexts in which corona appeared. By the thirteenth century ius coronae, and indeed the totality of the king's legal position status corone - were in use. ${ }^{108}$ Thus, a clear distinction finally emerged between the person of the king and the impersonal institution; between rex, the temporary incumbent, and corona, the royal office; or perhaps, on a more abstract level, between the auctoritas of sacral rulership and the potestas of the office holder. ${ }^{109}$ The emergence of the clear distinction between rex and corona followed a general European pattern. ${ }^{110}$ Neither in Hungary, nor elsewhere in Europe, did the making of the distinction involve a concept of the 'State'"11 as the legally organized society or community. Further, the distinction, as we shall see, did not lead in medieval Hungary to a corporate political conception of the crown. The king habitually referred to corona as his own: corona nostra regia. ${ }^{112}$ And later when the crown was predicated on the regnum Hungariae, it was either the king's regnum or regnum in the (territorial) kingdom sense. Normally, the capacities that inhered in corona, the office, concerned the incumbent to the exclusion of others.

The king in Hungary wielded near despotic power based on, by West European standards, an enormous patrimonium. He was dominus terre (private) lord and ruler to whom and to his crown all inhabitants were

108 Ibid., 22f., 47-48; Ferenc Eckhart, 'The Holy Crown of Hungary' (hereafter, 'The Holy Crown'), The Hungarian Quarterly, 6, i $940 / 4$ I, pp. 633, 639.

109 József Deér, 'A szentkorona eszme története' (hereafter, 'A szentkorona') Századok, 76, I 942, p. 203; yet rex could still have more abstract uses. At the coronation ceremony of Maria Theresa in I 74 I the nobles shouted: 'Vivat Domina et rex noster!', Bartoniek, A m. királykoronázások, p. I62.

110 On the distinction between the person of the king and the 'crown' representing the king as an institution in Europe, see Fritz Hartung, Die Krone als Symbol der monarchischen Herrschaft im ausgehenden Mittelalter (Abhandlungen der preussischen Akademie der Wissenschaften, Phil.hist. Klasse Nr. I 3, I 940 (hereafter, 'Die Krone'), repr. in Hellmann, Corona, pp. I-69; Kantorowicz, The King's, pp. 358-6o.

111 At this point nearly all historians (even Marczali) take a leap in the dark insisting that when corona is clearly distinguished from rex it becomes the 'subject' or the 'personality' of the State: Marczali, Hungary, p. 303. Other historians, going even further, assume that the crown ever since St Stephen has 'symbolized the Hungarian state', for instance Bartoniek, 'Corona', p. 529. Eckhart assumed in I 94 I (but, as we shall see, not earlier) that the change, leading to the concept of the 'State', gradually evolved from the late fourteenth century: Eckhart. Szentkorona, pp. 72, 79, 81, 84-87, io2 (!); also, Eckhart 'The Holy Crown', pp. $637 f$. József Deér rightly pointed out in his book review that Eckhart was wobbly and partly contradictory in his use of terminology: 'We cannot share, however, his view that from the end of the fourteenth century the crown in external relations became a symbol of the State. It all depends on what we mean by the State and the extent to which we can shed its modern associations', Deér, 'A szentkorona', pp. 203f. Bertényi follows the traditional Hungarian thesis rather than Deér: Szent Korona, pp. I 45 and I 48. Fritz Hartung wrote that the crown in sixteenth-century Europe, following Bodin's work, lost its importance in representing the royal office (as opposed to the king's person) and the 'crown' was replaced by the abstract idea of the 'State': 'Die Krone', in Hellmann, Corona, p. 48. However, this process began only in the seventeenth century in Western Europe and it had not yet affected Central and Eastern Europe. See Quentin Skinner, 'The State', in Terence Ball et al. (eds), Political Innovation and Conceptual Change, Cambridge, i 989, pp. 9o- I 3 I .

112 Eckhart, Szentkorona, pp. 76-77; Bak, Königtum, pp. 22-23. 
subjected without distinction. ${ }^{113}$ All subjects owed allegiance to the king and his office as fideles coronae regiae. Loyalty was demonstrated through servitium nobis et regiae coronae which, if exceptional, invoked gratia and donatio by the king. ${ }^{114}$ And contrariwise, lack of loyalty towards the king, nay rebellion against him, was treason, violation of allegiance to corona. ${ }^{15}$

Papal intervention was at times decisive in the affairs of the kingdom and, correspondingly, the Church and the Holy See had strong influence on the growth of ideas associated with the crown in Hungary. ${ }^{116}$ In order to uphold the royal dignity the pope enjoined the king to preserve his patrimonium by revoking lands alienated by him or his predecessors to the detriment of his office. 'At your coronation', wrote Pope Honorius III to King Andrew II in I 220, 'you swore to preserve the rights of your royal office and the dignity of your crown unimpaired.' 117 The inalienability of the royal patrimonium was then, in the fourteenth century, extended to the whole territory of the corona regni Hungariae. The king, the temporary incumbent, could not alienate any part of the kingdom to another country, this being detrimental to the crown: the unity of the kingdom. The king at his coronation took the Oath to recover alienated land, lost from the kingdom's territory, 'to the possession of the Holy Crown'. ${ }^{118}$ The royal revenues were said to be crown revenues, kept in the crown's treasury, which was, however at the sole disposal of the king. ${ }^{19}$ The same went for the crown's right of escheat: land without rightful heir reverted to the

${ }^{113}$ Eckhart, Szentkorona, pp. 35f., I 04-05; idem, 'The Holy Crown', p. 639; Martyn Rady, Nobility, Land and Service in Medieval Hungary, London, 2000 (hereafter, Nobility), p. I 6.

${ }_{114}$ Váczy, Szimbolikus, pp. 3if.; Eckhart, Szentkorona, pp. 45-49; Agnes Kurcz has pointed out that because of the fear from attack by the Tatars fidelitas played a central role in the relationship between the king and the nobility in the second half of the thirteenth century: 'Arenga und Narratio ungarischer Urkunden des I 3. Jahrhunderts', Mitteilungen des Instituts für österreichische Geschichtsforschung, 70, I 962, pp. 322-54 (pp. 337-42).

115 Ibid., p. 45 .

116 Karpat, 'Corona', p. 347. The author points out that crown uses were more prominent in Hungary than in Bohemia and Poland because of Hungary's proximity to Rome; Eckhart, Szentkorona, pp. 33-34, 49-54. Eckhart throughout his work placed his subject in a wide European context and in a separate chapter looked at Hungary's neighbours. He noted that the crown in Bohemia became a corporation of the estates in the fifteenth century (the Hungarian development was more conservative). In Poland the territorial unity of the kingdom dominated crown uses. The distinguishing feature of the 'crown' in Hungary was the central importance of fidelitas, pp. I 42-58.

117 Eckhart, Szentkorona, p. 22; idem, 'The Holy Crown', p. 634; Kantorowicz, The King's, pp. 354f. The inalienability of the rights of the crown developed in much the same manner in many European countries, ibid., pp. 345 f. The unity of the crown was affected neither by the Arpád's custom of dividing the ruling of the kingdom among the male members of the house (ducatus) nor by the short lived institution of junior rex, introduced by Béla IV in I 262 whose son had already been crowned in I 246. See Gyula Kristó, A feudális széttagolódás Magyarországon, Budapest, I979, pp. 33-34, 37, 54f., passim. See Eckhart, Szentkorona, pp. $44-45$.

Szentkorona, pp. i05-I2, I I6f., I40; idem, 'The Holy Crown', p. 639.

119 Ibid., idem, Szentkorona, p. I I I. 
crown, the radix of all property, that is the royal office. ${ }^{120}$ Werbőczy, a high judge in royal service, wrote in $\mathrm{I} 524$ that his duty was to administer justice to all who sought it, including Jews and Gypsies, if they were subjects of corona regni Hungariae. ${ }^{121}$

A telling example that shows the indivisibility of the crown's authority lies in respect to the arrangements made under interregnum. In I 40 I the royal dignitaries kept King Sigismund prisoner in Visegrád Castle for six months. During this time the Primate of Hungary as Chancellor acted auctoritate iurisdictionis corone rather than, as usual, regia auctoritate. He engraved a new seal, sigillum sacre corone regni Hungariae. The soon forgotten arrangements arose clearly as a temporary substitute which the clear distinction between the physical king and the royal office made possible. ${ }^{122}$ The incident did not lead either to institutional or conceptual change ${ }^{123}$ but similar arrangements obtained on other occasions. During the interregnum that followed the death of Vladislav I, János Hunyadi, as regent from I 446, acted by reference to the Holy Crown in the absence of the king, a minor. ${ }^{124}$ Article XIV 1446 instructed the regent that repossessed mortgaged properties should be returned to the crown for the king (ea Coronae reapplicando Domino Regi reservare). ${ }^{125}$

These cases amply demonstrate that the distinction between rex and corona was between the incumbent and the office. The capacities of the Holy Crown were not shared; the crown was not a super-body which embraced the king and the estates. ${ }^{126}$ This does not mean, however, that the Church, the barons, the nobility and, from the fifteenth century, the diet were not institutionally connected to the responsibilities of the king and, thereby, to those of the Holy Crown. ${ }^{127}$

120 The idiom 'sacra corona radix omnium possessionum', has sometimes been attributed to Werbőczy, at other times to Imre Kelemen. I could find it neither in the Tripartitum nor in any editions of the Institutiones juris hungarici privati.

${ }^{121}$ Letter to András Báthory on 27 February I 524 quoted by Eckhart, Szentkorona, p. I05 n. 8 .

122 Ibid., pp. $79-82$.

${ }^{123}$ Eckhart thought that the incident made the Holy Crown 'the sole subject of state power', ibid., p. 79 .

124 Ibid., pp. 99-i I

125 M. G. Kovachich (ed.), Vestigia comitiorum apud Hungaros, Buda, I 79o, p. 26o; János M. Bak et al (eds), The Laws of the Medieval Kingdom of Hungary, 3 vols, I 992- I 999 (hereafter $D R M H)$, 2, p. I 5 (English trans.).

${ }^{126}$ As far as I can see, only József Deér recognized this among Hungarian historians, see note I I above. There are one or two cases in which foreigners refer to the Hungarian crown as a 'community', for example, in a letter by the Polish Treasurer to Bártfa in I 438 : 'ac totam communitatem Hungarie sacre corona', Eckhart, Szentkorona, p. I 28 n. 62.

127 In comparing the growth of corona uses in Hungary and Bohemia Eckhart found that the imperative presence of a specific material crown made the Hungarian development more conservative than the Czech. Another distinguishing feature of the Hungarian practice was the centrality of the notion of fidelitas towards the royal and later the ország's crown, which was associated with the system of royal land donation. See below, Eckhart, Szentkorona, pp. I 5 I-53. 


\section{Corona regni}

The king in Hungary, as in other Christian kingdoms, had duties toward the Land and his subjects. These obligations arose from the mode in which power was transferred to him. The rex haereditarius, the legitimate successor, was duty-bound to arrange his coronation, as we have seen, with the Crown of St Stephen, ${ }^{128}$ officiated by the Roman Catholic hierarchy in the presence of the kingdom's high dignitaries, the barons. A splendid pageant, at which Hungarians always excelled, the inauguration was not merely a formal ceremony of investiture. From the late Middle Ages, it had to be performed diaetaliter as a bestowal of authority, transferred to the king after hard bargaining with the assembled estates. This contractualist character of the coronation was maintained until I9I8. ${ }^{129}$ The king had to take a solemn oath in church ${ }^{130}$ and from I 687 enact, in decretum form, the Inaugural Diploma in which he promised to defend the kingdom and its inhabitants, to recover and reincorporate with the kingdom lost territories as well as to maintain the ancient privileges, laws and customs unimpaired. ${ }^{131}$ Further, when the deceased king had no legitimate heir, the bishops and the barons, and later the whole landed nobility of the regnum, the ország, claimed the right to 'choose' a king at

${ }^{128}$ After I 790 within six months of his accession, as stipulated by Art. III of I 790 following Joseph II's ten years of 'unconstitutional rule'.

129 Antal Csengery's diary preserved Deák's comment made on I I June i 867, the day of Franz Joseph's coronation, that the nation in the Diploma 'renews the contract' with the new incumbent: Lóránt Cisengery (ed.), Csengery Antal hátrahagyott iratai, Budapest, i 928, p. 94. The Conservative Pál Somssich, President of the House, said in an electoral address in 1869 that the coronation was a 'reinforcement of the mutual contract which the nation had made with the Habsburg House in I 723': Miklós Somssich (ed.), Somssich Pál beszédei, Budapest, I 942, p. I 07. Miksa Falk in I 892 described the coronation as 'the external sign of the agreement between the monarch and the nation as regards their mutual rights and duties': 'A koronázás közjogi jelentősége', in Dénes Kovács et al. (eds), Koronázási Emlékkönyv, Budapest, I 892, p. 25.

130 The king swore to observe 'the immunities, liberties, rights, laws, privileges, the good old approved customs' of the prelates, barons, nobles and all the inhabitants of the kingdom, to dispense justice to all, and to respect the decretum of Andrew II, the Golden Bull of I 222 with the exception of the clause on the right of resistance. He would not alienate any part of the kingdom's territory and would promote the common good. The royal Oath's text was included in the decretum issued at the time of the coronation. On the Oath in the Middle Ages see Emma Bartoniek, 'A koronázási eskü fejlődése i526-ig', Századok, 5I, igi7, pp. $5-44$.

31 For the medieval antecedents and capitulationes of the 'elected' kings, see Bartoniek, $A \mathrm{~m}$. királykoronázások, pp. 54-57; András Kubinyi, 'Die Wahlkapitulationen Wladislaws II. in Ungarn', in Rudolf Vierhaus (ed.), Herrschaftsvertrage, Wahlkapitulationen, Fundamentalgesetze, Göttingen, I 977, pp. I 40-62. The Diploma of Joseph, enacted in January I 688 (not yet in decretum form), was arranged under five headings: the confirmation of rights; the Holy Crown to be kept by its Keepers in the country; the reincorporation of reconquered territories with the kingdom and its adjoined parts; the right of the estates to elect the king in accordance with their ancient custom to remain intact (from I 723 after the Karl, the Joseph and the Leopold branches of the dynasty become extinct); a promise that all the successors would arrange their inauguration diaetaliter, take the Oath and issue the Diploma. See Marczali, Hungary, pp. 350-52. 
their assembly, the diet, which developed in the fifteenth century. ${ }^{132} \mathrm{In}$ this sense the Holy Crown became the ország's crown. ${ }^{133}$ But the powers of the crown belonged to the king and those who acted on his authority or, in very exceptional circumstances, those who temporarily acted on behalf of the royal office without the king (as in I 40 I). The ország, by transferring the potestas of the office to the new incumbent, legitimized the transition by reference to the auctoritas of the Holy Crown. For the mechanism of royal land donation changed the relationship between the king and organized society. The prelati et barones, through the royal council, acted as power brokers, and in the fifteenth century the servientes regis, the landed nobility of the self-governing counties, brought forth the diet of the ország. For all this, the estates shared power with the crown, rather than with the king in the crown. ${ }^{134}$

Indeed, the institutions of the kingdom moved quite in the opposite direction. Side by side with the monarch's regnum, the term in its other, ország, sense stood for the politically organized society seen as a corpus, a body with 'members'. ${ }^{135}$ The organic metaphor (used widely in Europe) was in Hungary applied first to the prelati et barones ${ }^{136}$ and then through gradual extension to the collective rights of the landed nobility as a whole. The members of the ország formed a universitas of a sort,

\footnotetext{
132 Emma Bartoniek, 'A magyar királyválasztás', pp. 385f.; Elemér Mályusz, 'A magyar rendi állam Hunyadi korában', Századok, 91, I957, pp. 46-1 23, 529-602; Bak, Königtum, chs 3 and 4 .

133 Bartoniek, 'Corona', pp. 325-27; Eckhart, Szentkorona, pp. 96-99. Per contra József Deér argued that regnum in the phrase corona regni should be translated as 'kingdom' rather than 'ország' (see next footnote). Deér might have been right for many cases before the Habsburg period, but not after. Also the four laws passed by the diet between I 464 and I 500 about the protection of St Stephen's Crown clearly shows the ország's involvement with the visible crown.

${ }^{134}$ Today most Hungarian historians are less than willing to accept this distinction even though the two leading authorities on the subject, Ferenc Eckhart and József Deér, emphatically argued that the 'transference' of corona and 'participation' in the office of corona must be clearly distinguished from each other. See 'Deér, 'A szentkorona', esp. pp. 204-05. ${ }^{135}$ In the bipolar world of Hungarian politics regnum was either the monarch's or the ország's and was used in two different clusters of senses (see Rady, Nobility, pp. I6 and I 72-73). It was either coterminous with corona and embraced the whole territory of the Hungarian crown (the 'kingdom' sense) or it meant the Land, which, as a repository of right, was coterminous with the Hungarian nobility and its territory, Hungary proper (the ország sense). Werbőczy juxtaposed regnum Hungariae with Dalmatia, Croatia, Slavonia and Transylvania: Tripartitum, Pt. III, Tit. 2. On the other hand, regnum Hungariae in the royal Oath and the Inaugural Diploma was coterminous with the whole territory of the Holy Crown. Both uses survived into the nineteenth century.

136 The papal nuncio Gentilis enjoined the prelates and barons to obey Charles Robert in I 309 who they had recognized as king 'cum non liceat a capite membra discedere', quoted by Bartoniek, 'A m. királyválasztás', p. 398 n. 2.
} 
sometimes referred to as the totum corpus regni Hungarie. ${ }^{137}$ Just as the king exercised customary rights vested in the crown, the diet exercised corporate rights and privileges vested in the noble ország, the Land: Hungary as a possessor of rights. This structural dualism developed in the fifteenth century; it was exacerbated after I 526 when the Hungarian crown was acquired by the alien Habsburg dynasty. It became a central feature of the political institutions that the crown and the noble ország existed side by side as two distinct and largely separate repositories of right and authority which were mutually complementary and functioned alongside each other in conflict and accommodation. ${ }^{138} \mathrm{~A}$ notable common feature in the uses of corona, regnum (in its ország sense), comitatus, voivod(atus) of Transylvania and ban(at) of Slavonia and Croatia was that these terms signified territory, office, rights of authority or merely an incumbent or a group.

The Land (territory) of Hungary, the ország as a subject of right and the magyar nemzet (Hungarian nation) of the nobility were coterminous. The crown of Hungary, in addition to Hungary proper, ruled over other Lands, notably Croatia-Slavonia and Transylvania, both of which had their own distinct dualistic systems of rights. Werbőczy referred to Dalmatia, Croatia, Slavonia and Transylvania as regna that had long been subjected and incorporated with sacra videlicet corona regni hujus Hungariae. ${ }^{139}$ If by the State we mean a more or less integrated system of law, we could find it neither in respect of the territory of the crown nor of any of its Lands. For centuries, the kingdom was an acute case of legal-institutional bipolarity (Doppelpoligkeit) ${ }^{140}$ which had a

137 Bartoniek pointed out that in this form the communitas totius regni Hungariae and totum regnum Hungarie were synonyms and that they referred to the estates in juxtaposition to the king: Bartoniek, 'Corona', pp. 328-29; Eckhart showed that both the royal council and the diet were seen as bodies with members. Charles Robert called together a diet in I3 I 8 'omnes et singulos, qui se regni nostri membra existimant' (Szentkorona, p. I79 n. 6I) and that by the middle of the fifteenth century all nobles were regarded as members of the ország (ibid., pp. I 8 If.) as well as the royal free towns of Hungary and sometimes even Dalmatian towns like Ragusa (Dubrovnik). See Bak, Königtum, pp. 74-77.

138 On the system of Doppelpoligkeit in the estate constitutions in general, see Otto Hintze, Staat und Verfassung, Leipzig, I94I, esp. pp. I I I-I3; Otto Brunner, Land und Herrschaft, Vienna i97o, esp. pp. 437f.; Ferenc Eckhart, A magyar alkotmányfejlödés, Budapest, i93 I (hereafter, Alkotmányfejl.), pp. I 5- i 6.

139 Tripartitum, Pt. III, Tit. I § I. Regnum Hungariae, territorially referred either to Hungary proper (like in partes regni Hungariae), the counties attached to Transylvania in the Ottoman period or, alternatively, to all regna under the Hungarian crown as in the Inaugural Diploma. Art. XVIII of I 74 I offers clear examples for the two uses.

140 See László Péter, 'Die Verfassungsentwicklung in Ungarn' (hereafter, 'Verfassungsentwicklung'), in Helmut Rumpler and Peter Urbanitsch (eds), Die Habsburgermonarchie I848-I9I8, Vienna, 2000, 7, pp. 249-52; Martyn Rady has discussed Doppelpoligkeit and its limitations in his Nobility, pp. I 58-6 I. He rightly criticized adherents of Doppelpoligkeit who posit 'the existence of only two separate subjects of right, ruler and estates', for the medieval polity was indeed 'multicellular'. Yet, when we look at the diet in Hungary we find it increasingly being dominated by the dialogue, tractatus, between the two actors and this is strongly reflected in the structure and style of the decreta up to i 867 . 
lasting effect on political attitudes and rhetoric. The bipolarity became a potent source of political nationalism after i 790. All in all, while organological forms, involving persons, social groups and territories, appeared in abundance when predicated on ország/regnum, the uses of corona affected by the simile were confined to a few contexts. ${ }^{141}$

\section{Werböczy on the Holy Crown}

István Werbőczy's Tripartitum, ${ }^{142}$ published in I 5 I 7 planted the seeds of a new Holy Crown tradition. Medieval Hungary's distinguished juristpolitician habitually and consistently uses the term sacra corona in his customary in its traditional forms, based on the distinction between the king's person and his office. ${ }^{143}$ In a single instance, however, Werbőczy in the Tripartitum refers to the landed nobles as membra sacrae coronae. ${ }^{144}$ The use of the organic crown metaphor suggests a body politic which comprises both the king and the nobility. ${ }^{145}$ By placing the metaphor in its proper context we should, however, come to the conclusion that Werbőczy's crown simile has very little to do with any corporate political conception.

Where Werbőczy asks the question Qui possint condere leges, et statuta?, ${ }^{146}$ that is, where he discusses the political arrangements of the kingdom, he does not bring in the organic metaphor. He tells us at the beginning of his work's Second Part that while the Hungarians were still pagans their dukes and captains made laws for them:

After they [the Hungarians] converted to the Catholic faith and freely elected their king, they transferred the power and right to make laws,

141 The one or two odd cases of organological corona uses applied to persons are mostly in foreign sources: Bartoniek, 'Corona', p. 327 n. 5, 328 n. I; Eckhart, Szentkorona, pp. I 27-28, I40. Officials of the town of Ragusa in their diplomatic correspondence in the fifteenth century frequently extended the organological uses of ország to corona, the town describing itself as a member of the ország as well as the Holy Crown. Eckhart emphasized that the use was 'purely territorial': ibid., pp. I $93^{-96}$ and see note $15^{8}$ below. For the territorial organological corona uses, see further on pp. $45_{2 \mathrm{f}}$ and $45^{8 \mathrm{f}}$.

142 Werbőczy, Tripartitum, see note 76 above. The diet commissioned Werbőczy, protonotary of the High Court, to collect the country's laws. The draft, approved by a committee, attained royal approbatio, but the work was never promulgated by the king in a decretum. The Tripartitum was to become the book in Hungary which, apart from the Bible, attained the highest number of editions (said to be around fifty).

${ }_{143}$ To ignore this fundamental fact, as many historians do, is itself a major failure of scholarship. Herewith a sample of references to passages in the Tripartitum where Werbőczy's use of the Holy Crown is entirely traditional: Pt. I Tit. $3 \S 6$, Tit. $9 \S 6$, Tit. I o $\S$ I, Tit. I $3 \S \S$ 2,4 and 5, Tit. I 4 2, Tit. I $6 \S 6$, Tit. 24 Preamble, Tit. 26 Preamble, Tit. $37 \S \S 2,5$ and 8 , Tit. 64 Preamble and § I, Tit. 66 § 4; Pt. II Tit. 3 § 2, Tit. I 4 § 3 I, 34, 37 and 43, Tit. $39 \S$ 3 ; Pt. III Tit. I $\S$ I. It is even more telling that Werbőczy sometimes refers to the reversion of property to the Holy Crown as jurisdictione regia ( $\mathrm{Pt}$ I Tit. $65 \$ \S 3$ and 5 ) or fisco regio ( $\mathrm{Pt} 47$ § 2). See also, Eckhart, Szentkorona, pp. I 97-99, and Bak, Königtum, p. I 22 n. 32.

${ }_{144}$ Pt. I Tit. 4, para. I.

145 This is the conclusion of most Hungarian historians. They ignore Eckhart's contribution on this critical point, see Szentkorona, ch. I o.

${ }_{146}$ Pt. II Tit. 3. 
donating land and administering justice together with the rule and government to the jurisdiction of sacrae regni hujus coronae with which all the kings of Hungary are crowned, ${ }^{147}$ and consequently to our legitimate king and prince. And from this time onwards the kings have made laws by summoning and consulting the people as it happens in our age too. ${ }^{148}$

There is no sign of any corporate political theory, embracing the king and the nobility, in this passage.

In order to explain the organic simile, used in a single instance in Pt. I of his work by Werbőczy, we should start with the politician rather than the jurist. For Werbőczy was the leader of the nobility party at the diet which supported Count János Szapolyaí, the ambitious voivode of Transylvania, against the barons who ran Vladislav II's court. A promoter of elective kingship ${ }^{149}$ based on the landed nobility, Werbőczy announced, right at the outset of his work, his cardinal principle: Quod tam personae spirituales, quam saeculares, una et eadem libertate utantur. ${ }^{150}$ Within the nobility, Werbőczy claims, there were no legal differences. An opponent of the barons and leader of the 'nobility party', Werbőczy asserted the principle again and again:

all prelates, Church leaders, barons, other magnates and nobles and persons of rank in this kingdom of Hungary with respect to their nobility and the possession of temporal goods, una, eademque libertatis, exemptionis, et immunitatis praerogativa gaudent. ${ }^{151}$

This was a political programme rather than a legal fact. The legal positions of the prelates and the barons were always different from those of ordinary nobles. But this is exactly what Werbőczy (the leader of the nobility party) set out to deny. The nobility as a whole (including

\footnotetext{
147 Notably, Werbőczy does not yet distinguish the visible crown from the invisible corona. 148 Pt. II Tit. 3 para. 2. Werbőczy read the conditions of the fifteenth and sixteenth centuries into the period of the Árpád kings.

${ }_{149}$ An outstanding judge and silver-tongued orator, Werbőczy drafted the xenophobic 'Rákos Resolutions' at the diet in $\mathrm{I}_{505}$ against Habsburg succession in favour of native elected kings. On the politics of the period see Dezső Szabó, Küzdelmeink a nemzeti királyságért I $505^{-I} 526$, Budapest, I I 7, pp. 94-99; on the political ideology of the nobility party see Bálint Hóman and Gyula Szekfû, Magyar történet, 5 vols, Budapest, I 936, 2, pp. 592-95; Bak, Königtum, ch. 6; Engel, The Realm, pp. 349-5I, passim (a rather traditional account of Werbőczy's crown 'theory').

150 Title of Pt. I Tit. 2

$151 \oint \mathrm{I}$.
} 
the barons), the populus, which Werbőczy contrasted with the nonnobles, the plebs, ${ }^{152}$ enjoyed the same basic privileges which he lists further on. ${ }^{153}$

After the announcement of his cardinal principle of 'identical' liberty, Werbőczy immediately went into history in order to explain how the communitas, when the Hungarians were still pagan, had split into populus and plebs. ${ }^{154}$ As Eckhart has convincingly argued, Werbőczy's only interest here is to support by history the una eademque libertas principle and he entirely ignores the topic of political participation by the communitas. ${ }^{155}$ Here, Werbőczy explains that the Hungarians were, through the work of the szentkirály, converted to Christianity and:

By freely electing [Stephen] and crowning him king, the communitas by its free will transferred to the jurisdiction of the kingdom's Holy Crown and consequently to our prince and king, together with the rule and government, the right and the entire power of ennoblement and consequently of land donation which adorns and distinguishes the nobles from the non-nobles. Henceforth he is the source of nobility and the two things, owing to the reciprocal transference and mutual connection, are so interdependent that they are inseparable and unbreakable and the one cannot exist without the other. For the prince is elected only by the nobles and, in turn, the nobles are only created and adorned with that dignity by the prince. ${ }^{156}$

The thrust of this passage is that all nobles acquire nobility in the same way. Werbőczy then argues that nobility, earned by military or other services, is obtained by royal land donation. By virtue of this donation anyone endowed by the prince with a castle, an oppidum or a village

152 Pt. II Tit. 4.

153 These were the four cardinal privileges listed in the 'Titulus Nonus', Pt. I Tit. 9: (i) nobles may not be arrested by anybody without a writ issued by a court, (ii) they are subject to no authority except that of the lawfully crowned king, (iii) they are exempted in perpetuity from servitude, dues, taxes and custom duties of any kind, their only obligation being the taking up of arms when the kingdom is attacked, iv) if the king violates the liberties of nobles, they have the 'right in perpetuity to withstand and resist, by word and deed, without thereby incurring the crime of infidelity'. The last point, the ius resistendi, appeared for the first time in Andrew II's Golden Bull of I 222 (Art. 3 I). Werbőczy claimed that all the kings at their coronation had taken the Oath on the keeping of the Golden Bull (in fact, only some did). Art. IV of I 687 annulled the ius resistendi. Because this act did not acquire the 'tacit consent' of populus, the king at his inauguration and right up to igi 8 expressly excluded from his coronation Oath Art. 3 I of the Golden Bull. For the critical edition of the Golden Bull in English see Bak et al., DRMH, I, pp. 32-35.

154 Those who did not respond to the call up of the communitas of the Huns, that is the ancestors of the Hungarians, a communitas based on equality, were either executed or subjected to permanent servitude: Pt. I Tit. $3 \S \S 2-4$.

155 Following Elemér Mályusz, Eckhart explored the connections between Thuróczy's Chronicle ( I 488) and Werbőczy's digression into history to explain the division between the nobility and the ordinary people: Szentkorona, pp. 200-05. The ultimate source of Werbőczy and Thuróczy's account was Simon Kézai's 'hun story' in his thirteenth-century chronicle. Kézai in turn, as Jenő Szűcs argued, constructed his story on French analogies, 'Társadalomelmélet, politikai teória és történetszemlélet Kézai Simon Gesta Hungarorumában', Századok, I 07, I973, p. 595.

156 Pt. I Tit. $3 \S \S 6-7$. 
becomes a true noble provided he is lawfully installed. After this, he sums up his position with a passage that became a locus classicus in the nineteenth century:

And with us this donativa libertas is called nobility. Hence the sons of these nobles are rightly regarded as heirs and free. Such nobles, because of their endowments which we have just mentioned and of their connections, are considered as members of the Holy Crown, who are, apart from the lawfully crowned prince, not subjected to anyone else. ${ }^{157}$

It appears that for Werbőczy 'crown membership' is a mere simile to underline the thesis of una eademque libertas based on direct connections with the crown: and only such nobles (et hujusmodi nobiles!) who received (or inherited) land, donated by the king, were, because of that, called members of the crown. Contrary to what has been repeated ad nauseam in more recent years, even by historians, in the Tripartitum it is not the nobility as a whole who are called members of the Holy Crown but only those who benefited from royal donation of land, a minority within the nobility. ${ }^{158}$ And having established this, Werbőczy, very logically, gets down to discussing property rights, privileges and forms of donation and the organic simile never recurs in his work. ${ }^{159}$ The context in which Werbőczy used the organic metaphor was clearly fidelitas, service and land donation rather than the political rights of the communitas. He combined two precepts: the ország's crown, in the form of an elective kingship, and his controversial principle ${ }^{160}$ that all nobles,

157 Pt. I Tit. 4 I I. 'Et ista tandem donativa libertas, per nostrates, nobilitas appellatur. Unde talium nobilium filii, merito haeredes, et liberi nuncupantur. Et hujusmodi nobiles, per quandam participationem, et connexionem immediate praedeclaratam, membra sacrae coronae esse censentur; nulliusque, praeter principis legitime coronati, subsunt potestati.'

158 Less than one-third of the whole nobility: see Rady, Nobility, pp. I 55-57. Judicial practice followed Werbőczy in this respect too: see Béni Grosschmid, Magánjogi elöadások, Budapest, I905, pp. 237-38. Henrik Marczali made the point that royal land donation (rather than noble status) qualified for membership: Ungarisches Verfassungsrecht, Das Öfentliche Recht Gegenwart, vol. I 5, Tübingen, I 9 I I (hereafter, Ung. Verfassungs.), p. 28; and see notes I 4 I, 220 and 405 below. During the Dózsa peasant uprising on I 6 June I 5 I 4 Werbőczy, on behalf of four counties, requested the northern mining towns to send pixidarios (lancers or musketeers) against the peasants, 'quia eciam Dominaciones Vestras membra sacre corone regni huius esse scimus'. Zsuzsanna Hermann points out that the crown simile was hardly applied to towns, although rather exceptionally, in I 490 the metaphor was applied to Sopron in a missile regium. However, Werbőczy, an opponent of the towns, did not extend crown membership to them in the Tripartitum: Zsuzsanna Hermann, 'Egy pénzügyi tervezettől a Hármaskönyvig', Századok, i I 5, I 98 I, pp. I o8-5I (pp. I 30-32). Martyn Rady has drawn my attention to this case as well as to a similar one in an unpublished letter by Vitez de Kállai, ban of Szörény, to the citizens of Kassa (Košice) written in I 522 (MODL Df 27I232). Art. XIX I958 referred to the royal free town as property (peculium) of his majesty's crown. The town as koronajószág appeared in the legal literature, alternately, as peculium regium and as peculium sacrae coronae.

159 Eckhart emphasized this point: Szentkorona, p. 208.

160 In fact a very high proportion of the nobility served as familiares (servitors) of the Church and magnates, see György Bónis, Húbériség és rendiség a középkori magyar jogban, Kolozsvár ( I 944), pp. 2 I 7-3 I 2; Martyn Rady regards familiaritas as 'one of the distinguishing features of Hungarian noble society': Nobility, p. I I 2. 
as beneficiaries of the royal office, the Holy Crown, which was the single source of their donated land, were in law equal because they were not dependent on anybody else but the lawfully crowned king.

In sum, the evidence is simply not there in Werbőczy that his organological crown metaphor even prefigured the idea of political authority, let alone a system of public law, residing in the Holy Crown as a corporation which comprised the king as head and the noble ország as its members. It is then a remarkable feat of nineteenth-century scholarship that it was on Werbőczy's authority that his metaphor, used in a single instance and in a very different context, could become the main evidence to attest the evolution towards the concept of a unified system of public law and political authority.

\section{Reincorporation with the crown and the ország}

In the early modern age, as the kingdom became a part of the Habsburg empire, corona and ország moved apart. The royal prerogatives vested in the Holy Crown and the corporate rights of the ország or, as they were now called, the status et ordines of the counties and of the diet marked two separate spheres of right and authority. ${ }^{161}$ Their complementary relationships, the endemic conflict and accommodation between the two sides, provided the defining political tradition. The links between the offices of the Hungarian crown, mostly subordinated to Habsburg imperial offices, and the ország diet became tenuous. ${ }^{162}$

The tripartite division of the kingdom in the sixteenth century accounts for the predominance of the territorial senses in which the Holy Crown turns up in the proceedings of the diet and in the decreta. As elsewhere in Christian medieval Europe, the territory of the Hungarian crown was held to be inalienable. It was an obligation imposed on the king by the Oath he took at and the Diploma issued after the coronation that he might not alienate any part of corona territory. Or, inversely, should any part of the territory over which the king had a claim to rule, and consequently held of the Hungarian crown, be severed from the rest by any means, he had the obligation to recover what had been (temporarily) alienated and reincorporate it with the rest of corona territory, or, in other words, to bring it back under the king's rule. The crown was indivisible. The duty of reincorporation acquired special significance after I 54 I when Suleiman

\footnotetext{
${ }^{161}$ SS \& OO became the abbreviated form (Status et Ordines). The organological image of the ország survived into the early modern age: the landed nobility, the royal towns, Transylvania, persons as well as territories, are said to be its members; examples are given by Eckhart, Szentkorona, pp. 24of.

${ }_{162}$ See László Makkai, 'The Crown and the Diets of Hungary and Transylvania in the Sixteenth Century', in R. J. W. Evans and T. V. Thomas, Crown, Church and Estates, London, I99 I, pp. 80-9I.
} 
the Magnificent occupied large parts of the kingdom. The diet habitually demanded that the monarch should retake the lost territories and reincorporate them with the crown, and also with the regnum in its ország sense. In their territorial uses corona, like regnum, was regarded as a corpus with members. ${ }^{163}$ The two demands, when juxtaposted, did not necessarily refer to the same territory. From the sixteenth century, three regna, each with its own customary laws, offices and diet, coexisted: Hungary, Croatia and Transylvania. ${ }^{164}$ In the late seventeenth century the Habsburg army retook the territory hitherto under Ottoman rule and Transylvania reverted to the Holy Crown. There were some links between the ország of Hungary and the other regna. In the eighteenth century, Hungary and Croatia had some joint royal offices and Croatia also sent deputies to the Hungarian diet. ${ }^{165}$ But the Croat Sabor possessed autonomous statute-making power which attained the royal assent ${ }^{166}$ without reference to the Hungarian diet. There was no diaetalis link between Hungary and Transylvania. ${ }^{167}$ The estates of Transylvania declared in Art. I of I 744 that the Principality, which used to be sacrae regni Hungariae coronae membrum - and even then under its own voivode - later had separated from that regnum ${ }^{168}$ and acquired its own princes. The apogee of the process in which each of the three regna was regarded as independent of the other two was reached in I 790, just as the first move in the opposite direction was being attempted. After the collapse of Joseph II's system, all three regna declared $^{169}$ that they were entirely autonomous, not subject to any other Land.

In the eighteenth century the nobility demanded the reincorporation diaetaliter of all territories that used to be parts of Hungary, yet after

163 Eckhart, Szentkorona, pp. 222 ff. and 245 ff. 'Corona' and 'regnum' in their 'kingdom' senses were interchangeable, at other times regnum Hungariae referred only to Hungary proper, the ország.

${ }_{164}$ László Péter (ed.), Historians and the History of Transylvania, New York, I 993 (hereafter, Historians), pp. 8, I 2; and Martyn Rady, 'Voivode and Regnum', in ibid., pp. 87-i o I. Count Miklós Zrinyi adopted the phrase that can be found in all European languages, 'C'est un des plus beaux fleurons de la couronne', for Transylvania: Tóth, Szájrul, pp. $42-43$.

165 After the collapse of the Wesselényi conspiracy in I670 Croat and Hungarian aristocrats politically moved apart. Conflicts of competence between the two regna were tolerable as long as the deputies of the ország did not attempt to 'majorize' the two Croat deputies at the diet in Pressburg. On its own, Croatia carried little political weight in the eighteenth century. Although the three Croat counties together raised less tax than a single Hungarian county, Croatia became a distinct regnum in the ország sense.

166 Para. I, Art. I 20 of I 7 I 5. Croatia was, as Croats argued, subject to the Holy Crown, that is the king of Hungary, not Hungary (the ország) itself. The Croat estates offered to accept the Pragmatic Sanction on I 5 March I 7 I 2 without reference to the diet of Hungary: Joannes Kukuljević, fura regni Croatiae, Dalmatiae et Slavoniae, Zagreb, I862, 2, pp. I 05-07.

167 There was some support in Hungary for diaetalis union with Transylvania but none there before I 790, see Péter, Historians, pp. I 2- I 3, 22 and n. 43.

168 'ab eodem regno', here regnum in the kingdom sense.

169 See Péter, 'Verfassungsentwícklung', p. 26 I. 
their reconquest the crown had not reattached them to the ország. ${ }^{170} \mathrm{In}$ Art. XVIII I 74 I Maria Theresa promised that, subject to conditions, the counties of the so called 'Partium'171 and the Militärgrenze $e^{172}$ would be reincorporated; she partly kept these promises. ${ }^{173}$ Within a few years the Tisza-Maros Militärgrenze was dismantled and, towards the end of her rule, so were the Banat and Temesvár; the rest of the Militärgrenze was not. The Partium stayed with Transylvania but the thirteen towns of the Zips were reincorporated with Hungary at the First Partition of Poland in I 772. ${ }^{174}$ Galicia, which was then acquired by Austria by reference to the rights of the Hungarian crown, was not attached to Hungary. ${ }^{175}$ Neither the court nor the nobility regarded it as a part of the ország in any sense. Fiume was an interesting case. In order to provide the kingdom with a seaport on the Adriatic, outside the control of both the Croat and the Hungarian nobilities, Maria Theresa, in two moves in 1776 and 1779 , attached the town to the Hungarian kingdom ${ }^{176}$ as a separatum sacrae regni Hungariae Coronae adnexum corpus: ${ }^{177}$ hitherto the town had been a part of the Holy Roman Empire. The restoration of the royal land donation system throughout Hungary proper (to benefit the nobility) and the demands to re-establish the counties including their diaetalis reincorporatio, were the antecedents of the claim made after I 790 that the integrity of the ország should be restored. As we shall presently see, however, what the nobility was to understand in the nineteenth century by the 'restoration' of Hungary's territorial integrity amounted, in fact, to a major discontinuity with the past.

All in all, it is plain that for well over two and a half centuries after Werbőczy, neither his organic metaphor nor any other uses of corona exhibited any sign of development into a corporate political concept of the crown which comprised the king and the nobility.

\footnotetext{
170 Eckhart, Szentkorona, pp. 232, 270.

$171 \S 2$. Transylvania, to which the counties of eastern Hungary had been attached in the I 540 , was to be consulted.

${ }^{72} \S 3$. In the South of Hungary and parts of Croatia, instead of the restoration of the counties, the monarch introduced a military frontier system under the Hof kríegsrat.

${ }^{173}$ R. J. W. Evans, 'Maria Theresa and Hungary', in H. M. Scott, Enlightened Absolutism, London, I990, pp. I99-200.

${ }_{174}$ C. A. Macartney, Maria Theresa and the House of Austria, London, I 969, pp. I 42 f.

175 Endre Kovács, A lengyel kérdés a reformkori Magyarországon, Budapest, I 959, p. 57.

176 Regnum Hungariae in the 'kingdom' and emphatically not in the ország sense. Neither Croat nor Hungarian nationalists ever distinguished between the two senses of regnum and Maria Theresa's gift to the kingdom became a Pandora's Box between i779 and i9i8. Péter, 'Verfassungsentwícklung', p. 347.

177 Henrik Marczali, A magyar történet kútfóinek kézikönyve, Budapest, I 9o I, pp. 756 and 748 f., also Gyula Miskolczy, A horvát kérdés története és irományai a rendi állam korában, 2 vols, Budapest, I 927-I928, I, pp. 35-40 (p. 39 n. 2) (with robust Hungarian gloss).
} 
The Holy Crown uses in statute laws and government instruments

Evidence bears out Eckhart's observation that Werbőczy's simile became a point d'appui of new political and constitutional claims only from about I 790. ${ }^{178}$ The critical point is, however, that the new uses of the organic simile occurred in constitutional discourse, notably in political rhetoric and legal literature rather than in statutory law. The references to the 'Holy Crown' in the Corpus Furis Hungarici are overwhelmingly about the visible Crown of St Stephen rather than about the invisible crown. The articles on the coronation, the Diploma and the election of the Holy Crown's two Keepers ${ }^{179}$ all bear witness to the strength of the tradition attached to the jewel, of which we have already given a brief account. Whereas the constitutional role of the visible material crown can be properly attested through legal evidence, this is, apart from the uses of territorial integrity, missing for the new uses of the invisible crown. The point here is that, even after I 790, we do not find in the Lawbook a single instance where the Holy Crown appears as a political corporation embodying the king and the nobility or the nation. Also, it is less than clear whether the crown was ever used by the legislator to express continuous independent statehood. Whenever the invisible corona appears in the Lawbook it follows the earlier uses. This is the case with Werbőczy's organic simile which Art. XVI I79 I of Transylvania asserted by reference to the rights of the Transylvanian landed nobility. I have not found, however, a single instance of the Holy Crown membership idiom applied to persons rather than the territory in the Corpus Furis Hungarici. This omission is rather unexpected.

Following the established path of earlier centuries, apart from the territorial uses, the uses of 'Hungarian Crown' and 'Holy Crown' in the modern periods refer either to the (common) monarch, or the person of the king, or the royal office. In Art. XIX I 596 the estates supplicated 'his Majesty the Emperor' for the preservation of the Free Towns' liberty as they were [ipsi] peculium coronae suae majestatis. In the enacting clauses of the Hungarian Pragmatic Sanction, the so-called jus haereditarium succedendi in Hungariae regnum et coronam was extended to the female line. ${ }^{180}$ There can be little doubt that 'crown' here refers to the majesty of royal office to rule and govern the kingdom. It clearly emerges from Article VII of I 790 that the landed property of the sacra regni corona for the maintenance of royal office was at the king's disposal

\footnotetext{
${ }^{178}$ Eckhart, Szentkorona, p. 29o.

179 Tamás Katona published all the Laws concerning the Keepers and the protection of the Holy Crown from I464 to I928. See Appendix of his Korona, pp. 569-87. Even the republican Károlyi régime passed Néptörvény XXXI. On the safekeeping of the crown and the other regalia, see ibid., p. 580 .

${ }^{180} \S \S 5^{-9}$ of Art. II I 723 .
} 
and had nothing to do with the diet. ${ }^{181}$ Even a century later, when in I 895 Prime Minister Baron Dezső Bánffy argued in a submission to Franz Joseph that the Hungarian Holy Crown should be registered as the owner of Buda Castle, the monarch agreed, as Eckhart observed, 'because in his view the crown, as the symbol of rule, could only mean the monarch and under no circumstances that special community of the monarch and the ország which was advanced by public law'. ${ }^{182}$

The crown stood for the monarch in the basic laws of the nineteenthcentury constitutional conversion. In April i 848 at the Staatskonferenz dealing with the draft bill concerning the reincorporation of the Partium with Hungary, which was opposed by the chancellor of Transylvania, the view of the former Chief Justice Anton Cziráky prevailed:

Conflicts between Lands of one and the same crown, as, for instance, those in relation to the Partium, can be lawfully resolved only by decision of the common monarch. ${ }^{183}$

Law III of I848, which ordained the creation of an independent responsible ministry for Hungary, emphatically maintained 'intact the unity of the crown and the imperial connection'. Here, unmistakably, the rights of the Hungarian king were considered in conjunction with the responsibilities of Palatine István. The imperial crown was juxtaposed to 'the crowns of his Other Lands', from all of which Ferdinand had abdicated, according to the Diploma of Franz Joseph. ${ }^{184}$ Para. 7 of Law XII i 867, the Settlement Law, repeated the Pragmatic Sanction: 'the crown of Hungary is vested in the same monarch who also rules the Other Lands.' Law I i 875, 'On Incompatibility', stipulated that a member of the House of Representatives was prohibited from accepting any office which depends on 'nomination by the crown' (para. I). Law XXIII igor affirmed that Count Béla Széchenyi had been elected

181 Árpád Károlyi pointed out in 'Az I 848. III. törvénycikk történetéből', that until I 848 the revenues of the crown were the roval revenues in toto. Although some distinctions were made between different categories, they were technical rather than constitutional because the diet did not have a say in expenditure: Néhány történelmi tanulmány, Budapest, i93o, p. 5I I; Károly Miskolczy, Magyar Ország köz Joga, Eger, i 846, pp. 44-46, distinguishes various categories of crown property and revenue; they are all royal. Antal Ciziráky notes in his Conspectus Furis Publici Regni Hungariae ad Annum I848, Vienna, I 85 I, 2 vols (hereafter, Conspectus) in vol. 2, Caput XIV that the only firm rule is the inalienability of property.

182 Ferenc Eckhart, A volt monarchia udvartartásának vagyona, Budapest, I 928 (hereafter, $A$ volt monarchia), pp. 43-44. Eckhart meant, of course, by 'public law' the legal literature. Also, he emphasized that Buda Castle was the property of the 'king' as an institution, distinguished from the private property of the dynasty as well as other 'crown properties', like Gödöllö, which was 'pure Hungarian state property': ibid..

183 'Differenzen zwischen Ländern einer Krone, wie die hier vorwaltende wegen der Partium, gesetzmässig nur durch den Ausspruch des gemeinschaftlichen Regenten entschieden werden können.' On 8 April ı 848, Az I848-iki pozsonyi törvénycikkek az udvar elött, ed. Árpád Károlyi, Budapest, I 936, pp. 305-06. The editor disagreed, pp. I 52-53.

184 Preface of Law II I 867. 
Keeper of the Hungarian Holy Crown because of his work 'in the interest of crown and country'.

It should not surprise us that, in the liberal age, Hungarian law followed the general European practice in crown uses. The imperial connection, however, produced a few peculiarities. The programme of the Committee of Nine, agreed between Franz Joseph and incoming Prime Minister Count István Tisza on army reforms in October i 903 , referred to the political responsibility of the ministry which applied to 'every act of the crown'. As the context involved the monarch's reserved rights the 'crown' here referred to the ruler of the Austro-Hungarian Monarchy as a whole. ${ }^{185}$ The Treaty of Trianon enacted by Law XXXIII I 92 I likewise understood by the 'crown' the sovereign's rights of the whole Austro-Hungarian Monarchy (para. I77). These uses without exception followed patterns well established for centuries. Apart from the territorial uses of the Holy Crown, to which I shall soon turn, the only new crown use in the Corpus Furis Hungarici was a legal curiosity, nay oxymoron, born posthumously after the collapse of the Monarchy. Until i9 8 , justice was administered by the courts 'in the name of His Majesty the King' and, after Law I I 920 had been passed 'in the name of the Hungarian State'. The novel use came in with Law XXXIV I930 which ordained that 'the judicial power is exercised by the courts of State in the name of the Hungarian Holy Crown'. ${ }^{186}$

The central fact is that (at least before i 930) the Holy Crown did not become the Hungarian term for the 'State'. ${ }^{187}$ From thei 830 liberal constitutionalism aimed to carry out a conversion (átalakitás) of the whole constitution. The legal dualism of the mutually recognized rights and obligations of the crown and the ország was to be replaced by a system of public law based on the assumption that all public power had a single source, the State, whose impersonal regulations extended equally to everyone. As elsewhere in Europe, the 'State' grew out of

\footnotetext{
${ }^{185}$ József Barabási Kun (ed.), Gróf Tisza István képviselóházi beszédei, Budapest, I930 (hereafter, TIKB), I, p. 75 I, see Edmund Bernatzik, Die österreichischen Verfassungsgesetze, Vienna, second edn, igi i, p. 706 ('jede Handlung der Krone'). The programme was an agreement, a contract of sorts between the monarch and parliament's majority (rather than statute law) in which the latter was compelled to recognize the reservata of the former. In another place the agreement referred to the legislature as 'the crown and parliament together' where the 'crown' stood for the rights of the king of Hungary.

${ }^{186}$ Para I. Eckhart was justified to note that this innovation was 'the offspring of the new legal literature', Szentkorona, p. 265. Indeed, the Ministerial Motivation of the bill referred to the Holy Crown that 'embodies the sovereignty of thousand years' Hungarian statehood based on the ruler and the nation in its entirety': CFH, Márkus edn, Budapest, I 93 I, p. 469, n. I.

${ }^{187}$ Eckhart, Szentkorona, pp. 263-64.
} 
status, ${ }^{188}$ in Hungarian álladalom, ${ }^{189}$ and from 1850 , állam. In the new vocabulary, the 'State' was sometimes predicated on the Empire of Austria, which included Hungary, at other times on Hungary itself. 190 The April Laws of 1848 referred to the liberal representative system introduced in Hungary as álladalom. ${ }^{191}$ Henceforth, the traditional intercourse between the crown and the ország acquired a new dimension with the enigmatic quodlibet of 'Austria' versus 'Hungary'. Indeed it was the rival claims to statehood, culminating in the claim to GesammtMonarchie in the I849 March Constitution and the Independence Declaration of the magyar álladalom, that the War in 1848-49 was about. ${ }^{192}$ After Világos, die Krone, in the enactments of the centralized Austrian State, referred either to the person of the autocrat or his rights. The 'state' now transformed the vocabulary of law and political discourse. Throughout the Dualist Era the Hungarian legislator invariably employed állam rather than crown or Holy Crown for the notion of legally organized society. There was, nevertheless, one new class of crown uses, which was introduced in the Lawbook with the nineteenth-century conversion of the constitution.

\section{The Lands of the Hungarian (Holy) Crown}

The crown became the territorial reference for the unitary Hungarian national state. To begin with a summary: before I 790 the rights of the ország were predicated on the territory of Hungary proper. After I 790 the diet of the ország claimed the right to legislate for the other Lands (regna) under the Hungarian crown. And from the i83os the liberal nationalists called for all the Lands of the Hungarian crown to be united in a single governmental system. This claim was a part of the programme for the establishment of a Hungarian State. The claim was partly based on the liberal vision of civil society, which was to establish legal equality for all, and also on the ország's historical rights. ${ }^{193}$ And

188 The estates claimed in I 790 that Transylvania was a part of the status Hungarici, Eckhart found this early reference: Szentkorona, p. 264.

189 Állomány and közálladalom were possibly the earlier forms of status: see Béla Szabó, $A$ magyar korona országainak státusjogi és monarchiai állása a pragmatica sanctio szerint, Pozsony, i 848, P. 5 .

190 Hungarian authors frequently did both, sometimes in the same work: for example, Baron Zsigmond Kemény, Forradalom után, Budapest, i 9o8, pp. 9, i 3, 53, 328, 37 if; Pál Somssich, Magyarországnak és királyának törvényes joga, Vienna, i 85o, pp. 78-79, 85, 88, 94f. 191 See Laws XIII §3, XIV §3, XVIII§6, XX §8.

192 On this subject, see Péter, 'Verfassungsentwicklung', pp. 272-75 and 29 I-94. Paradoxically, Hungarian historians, axiomatically and sub specie aeternitatis, identify the Holy Crown with the 'Hungarian State' yet the 'crown' is entirely missing from the Independence Declaration, the very first authoritative document which asserted the Hungarian State principle (in I 849 ).

193 Ibid., pp. 262-65. Kossuth, then leader of the Opposition, in December I 847 questioned the very existence of Croatia as a Land. He insisted at the diet that under the Hungarian Holy Crown only a single historical nation existed, the Hungarian, in order to claim the right to a single common legislature. 
history had to be subjected to heavy massage to support the claim to the State with its modern system of government. The medieval precept of reincorporatio with the Hungarian crown, through conversion of sorts, reappeared as the territorial and political integrity of the unitary Hungarian State based on the Hungarian language. ${ }^{194}$ This historic right argument for the creation of a Hungarian State, which was to replace the system of three regna under the crown, amounted to constitutional innovation by reference to pre-existing right. ${ }^{195}$ The April Laws of 1848 ordained the creation of 'the complete álladalmi unity of the territory under the Hungarian Holy Crown'. ${ }^{196}$ Thus when the Law 'On the Unification of Hungary and Transylvania' confirmed the traditional precept that 'Transylvania belongs to the Hungarian Crown', ${ }^{197}$ in fact, it asserted a new claim. The Law was to defend the territorial integrity of a fundamentally reorganized kingdom. Law XVIII 'On the Press' made it an offence to incite against 'the complete state unity of the territory under the Hungarian Holy Crown' (para. 6).

In 1848 the attempt to unify the three regna of the Hungarian Crown, notably Hungary proper, Croatia and Transylvania, turned out to be a failure. But the aim was pursued, on the basis of the April Laws in I 86 I, and was successful in 1867 when by virtue of the constitutional settlement (Ausgleich) Hungary attained Home Rule and centralized government over the territory of what Ferencz Deák termed 'the Lands (országok) of St Stephen's Crown'. ${ }^{198}$ The crown was used consistently by the law to express the territorial integrity of the enlarged Hungary from i 867. Franz Joseph referred to himself in his Diploma Inaugurale as 'the lawful and true successor to the throne and crown of Hungary and its Associated Lands'. The 'Lands of the Hungarian Crown', a stock

\footnotetext{
194 Hungarian nationalists forgot the historical background when they claimed 'the principle of one crown, one state, one language', wrote Eckhart, Szentkorona, p. 277. See also data on the subject in Gyula Szekfû, Iratok a magyar államnyelv kérdésének történetéhez, Budapest, I 926, pp. 2 I 4, 550, 588. The diet on I I June I 790 resolved that in schools Hungarian be taught in all the parts that belonged to the Hungarian crown.

195 In a very similar fashion, Croat nationalists claimed the trojedina kraljevina the Triune Kingdom) which comprised three regna: Croatia (the medieval Slavonia), the three countries of lower Slavonia (which before the Turkish occupation had belonged to Hungary proper) and Dalmatia.

${ }^{196}$ Law XVIII § 6. The Proclamation of the diet (probably drafted by Kossuth in the first days of April I 848) announced: 'Diverse nations are united under the Hungarian crown, they all work on the great building of the álladalom': István Barta et al. (eds), Kossuth Lajos összes munkái, I 948-, I 5 vols (hereafter, KLÖOM), I I, p. 698.

197 Preface to Law VII i 848 . The diet asserted the competence of parliament to legislate for Croatia by referring to the Hungarian crown which represented the unity of the magyar közálladalom, KLÖM, I I, p. 699. It was implicit in the April Laws that regnum in its ország sense was coexistensive and interchangeable with the crown or regnum in the kingdom sense, but see note I 35 above.

198 See Péter, 'Verfassungsentwicklung', p. 348 n. 434.
} 
phrase of the Settlement Law, ${ }^{199}$ and (from I896) 'Holy Crown' remained the territorial reference of legislative enactments to the end of the Monarchy. Law XXX i868, a 'common fundamental law', declared that 'as Croatia and Slavonia in law and in fact have for centuries belonged to the Lands of St Stephen's Crown', they reached the following agreement with Hungary: 'Hungary and the Lands of Croatia, Slavonia and Dalmatia form one and the same state complex with respect to the Other Lands under His Majesty's rule as well as other countries' (§ I). Law L I879 declared 'citizenship (állampolgárság) to be one and the same in all the Lands of the Hungarian Crown' ( $\mathrm{I}$ ). In 1896 szent korona, as a new form, came into regular use: Law VII, which commemorated the founding of the Hungarian State, referred to the 'legislature of the Lands of the Hungarian Holy Crown'. ${ }^{200}$ Law XXXI ig 22 allowed, under some strict conditions, 'the employment of the honvédség [a second line force] outside the Lands of the Hungarian Holy Crown'. ${ }^{201}$ Franz Joseph sometimes adhered to the new rigeur, other times he did so with a twist in the tail. In his letter to parliament via the prime minister on 22 September 1903 the monarch referred to szent Koronám országainak integritása, i.e. 'the integrity of the Lands of my holy Crown'. ${ }^{202}$ The old bipolarity between 'crown' and 'nation' never disappeared from public life.

When the Austro-Hungarian Monarchy was about to disintegrate in October i 9 I 8 the government bill submitted in the House to separate Hungary from Austria declared: 'The Lands of the Hungarian Holy Crown constitute an önálló állam which is independent of all other countries.'203

In the interwar years Hungary did not accept the Treaty of Trianon which transferred over two-thirds of the kingdom's territory to Hungary's neighbours, and the law employed the Holy Crown to justify the (very temporary) successes of the 'territorial revisionist' policy pursued by successive governments. When between I 938 and I 940 the southern strip of the former Highland (Slovakia), Carpathian Ukraine and the northern part of Transylvania were reattached to Hungary,

\footnotetext{
${ }^{199}$ Law XII of I867, see preamble, paras. I, I8, 27, etc.. For instance $\S$ I9 referred to parliament as the 'diet of the Lands of the Hungarian crown'.

$200 \oint_{\mathrm{I}}$. The daily, Magyarország, reporting on the passing of the bill in the House, regretted the absence of the king in the session: 'as however the Holy Crown was present and wheresoever is this glorious treasure, there is the kingdom of Hungary', 9 June I 896, p. I. $201 \S 2$. The predecessors of this law on the honvédség, Laws XLI I 868 (\$3) and V I $890\left(\S_{2}\right)$, used 'Hungarian crown' rather than 'Holy Crown'. The editor of the CJH volume on the I 9 I 2 Laws observed that the latter designation was constitutionally more appropriate (p. I63 n. 3).

202 TIKB, I, p. 732

${ }^{203}$ Preamble to the bill On the Austro-Hungarian Personal Union, 20 October igi 8: Emma Iványi (ed.), Magyar minisztertanácsi jegyzóköonyvek az első világháború korából I gI 4-I9I8,

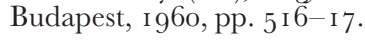


according to the Laws XXXIV i938, VI i939, and XX i940, these territories 'returned to the body of the Hungarian Holy Crown'. ${ }^{204}$

It is now time to sum up on the legal side of our enquiry. In the laws of modern Hungary the invisible crown followed the well trodden path in standing either for the monarch or the royal office. Alternatively, the law employed the crown to define territorially the modern centralized political system. Even in this new territorial sense the crown did not stand for the 'State' but, rather, 'piggy-backed' on it.

\section{The inveterate crown uses}

Contrary to what one might have expected, it was not constitutional law but political rhetoric and legal discourse within the Law Faculties that were the vehicles for the new ideas associated with the crown at every turn in their nineteenth-century history. And even here caution is in order. For even outside the law, in the overwhelming majority of its occurrences, the crown appeared in its well established senses denoting either the (common) monarch or the (Hungarian) royal office. ${ }^{205} \mathrm{~A}$ few examples will do. In Kossuth's rhetoric, the crown frequently stood for the monarch and he did not even separate consistently the Hungarian crown from the others. ${ }^{206}$ Count István Széchenyi hoped in I859 that a new pactum conventum could be made between the crown and the nation. ${ }^{207}$ Ferencz Deák had the rights of the Hungarian king in mind when he wrote that in I 723 'the nation had transferred the crown and its rights to the dynasty and not to the Austrian provinces'. ${ }^{208}$ On the other hand, in Deák's May Programme in 1865 , 'the crown' referred to the person of Franz Joseph as the holder of all his (undistinguished) monarchic rights. ${ }^{209}$ Prime Minister Gyula Andrássy regularly used the 'crown' in this sense. He admitted in the House to having interfered with Austrian affairs during the Hohenwart crisis, 'acting as the crown's adviser' rather than as a

204 Eckhart observed that the use of the term by the law followed historical tradition, Szentkorona, p. 288. Undoubtedly it did; however, the tradition had been rather less than a hundred years old.

205 'The separate existence of Transylvania is in our interest', wrote István Bocskai in his testament in I606, 'as long as the Hungarian crown is held by a nation, the German, stronger than ourselves': Erdély öröksége, ed. László Makkai, Budapest, i 993 (reprint), 3, p. I I 8 . Bocskai here had the royal office in mind but the crown frequently referred to the king. Eckhart held that the use of the crown as a synonym for king was of foreign origin: Szentkorona, p. 26 I.

206 See Kossuth's speech in County Zemplén on 24 January i83i, KLÖM, 6, p. 2 I 7 ; another example: 'the crown of His Majesty', in the Pesti Hirlap (1842), Kossuth Lajos, Íratai, ed. Ferencz Kossuth, Budapest, i go6, I 2, p. 254.

207 Miksa Falk, Széchenyi István grófés kora, Pest, i 868, p. 327.

${ }^{208}$ Deák, Ein Beitrag, p. I 47. In another place Deák, again referring to the 'transference of the crown', observed that the crown meant the 'Hungarian state', p. I o4.

209 Deák wrote on the joint management of the common affairs: 'the two deputations with each other and with the crown reach agreement', $D F B, 3$, p. 428. 
Hungarian minister. ${ }^{210}$ He viewed Austria-Hungary as a monarchic union of Lands with legal connections between 'the crown and the two states of the Monarchy'. ${ }^{211}$ In political tracts the crown was habitually used for the monarch; in the large numbers of Kákai Aranyos pamphlets the crown stood for the common monarch. ${ }^{212}$ These habitual uses of language went on in the twentieth century ${ }^{213}$ and we find them in parliamentary politics even after 'Holy Crown' began to replace 'Hungarian crown' in other contexts. Count Gyula Andrássy the Younger, in a proposal to the Liberal Party, continued with the old bipolarity, juxtaposing 'the power and lustre of the Holy Crown' and 'the rights of the nation'. ${ }^{214}$ 'The mutual trust between the crown and the nation' was a stock phrase in the vocabulary of politics. ${ }^{215}$ As the 'crown' here was (or could be) the king of Hungary this usage incurred no objection from any quarters. It was different with the description of the advisory body for the common monarch, alternatively called after I 867 'common ministerial council' and 'common crown council'. ${ }^{216}$ This use of the 'crown', by emasculating the claim to a legally sovereign Hungarian State, raised the hackles of many jurists in the early years of the twentieth century. ${ }^{217}$

Turning to the new uses to which the crown was put in political rhetoric, it is clear that the organic simile found in the Tripartitum was a potent source. ${ }^{218}$ Indeed, most of the new traditions that unfurled (or were invented) between the rule of Joseph II and the First World War were read into Werbőczy rather than into the innovations of I 40 I and I $440 .{ }^{219}$

210 In the House of Representatives on 7 November i87 I: Gróf Andrássy Gyula beszédei, Budapest, I 893, 2, p. 523 .

211 Andrássy Gyula gróf beszéde a véderö-törvényjavaslat tárgyában (5 April I889), Budapest, I 889, pp. 23, 29, 36f., 45; see also, Péter, 'Verfassungsentwicklung', pp. 5 I 3 n. г 286 and 525 n. I 354 .

212 For instance 'II-ik Kákai Aranyos' pseud. [Kornél Abrányi, the Younger], A leláncolt Prometheuszok, Budapest, I 88I, pp. 33, 40, I 08, I 50. The 'crown' is habitually juxtaposed to the 'nemzet'.

${ }^{213}$ For instance: 'Egy Dobzse-párti', in Se Bánffy se Wekerle, Budapest, I 903, p. 3 (a Korona). 21423 September I 903, TIKB, I, p. 733.

${ }^{215}$ For instance Franz Joseph's letter to Prime Minister Khuen Héderváry on 22 September i 903 , ibid., p. $73^{2}$.

${ }_{216}$ Protokolle des Gemeinsamen Ministerrates der Österreichisch-Ungarischen Monarchie (I9I4-I9I8), ed. Miklós Komjáthy, Budapest, I966, pp. 25, 46, 61, 83f., 89f.

217 One jurist, an adherent of the 'doctrine' of the Holy Crown, went livid about this use and also objected to the use of the 'crown' for the king: Gejza Ferdinándy, Korona és monarchia, Budapest, I903, pp. 7-I I.

218 See p. 45 I above.

219 Not much was known about the ideas of the political events in I 40 I and I 440 before modern scholarship brought them to light, see pp. I 5 and $23^{-24}$ above. 
The extension of the Holy Crown membership

From Werbőczy's time up to the nineteenth century membership of the Holy Crown, whenever it was predicated on persons rather than territory, applied to the beneficiaries of royal land donation rather than the nobility as such; the bulk of the nobility, the armalists and the curialists, were not yet considered members. ${ }^{220}$ The use of the metaphor could serve conservative purposes. In closing the diet in ${ }_{180} 5$ Emperorking Franz praised the deputies: 'You have understood the danger which threatens the Holy Crown of which you are members.' Archduke Charles Ambrose, Primate of Hungary, noted at the I 808 diet the need to maintain harmony between 'the head of the Holy Crown, the king, and its members, the status et ordines'. ${ }^{221}$ In opening the diet in I 825 Archduke Palatine Joseph welcomed the $S S$ and $O O$ 'together with whom I share membership of the Land's Holy Crown'.222 The Holy Crown membership in these cases did not serve Werbőczy's una eademque nobilitas principle based on fidelitas, service and land-donation; it was about partnership in the diet. However, county deputies (and even those representing absentee magnates), as Arts. LXII of i 625 and VII of I 723 confirmed, had to be owners of donated land, possessionati. Thus, the shift of context may not be regarded in itself as innovation.

Soon, however, Werbőczy's metaphor became an argument for noble democracy. This change had something to do with the new voting practice, introduced in the counties by the government in the late I8 I os which gave the landless nobility the right to vote at least at the elections to the diet. ${ }^{23}$ Crown membership was now tacitly

\footnotetext{
${ }^{220}$ Illés Geörch closely follows Werbőczy's Tripartitum. In his popular legal manual he points out that the royal donation letter does not have to mention even the nobility 'but only the landed estate (fekvö jószág), by virtue of which we become members of the Holy Crown'. The 'landless nobles' (jószágtalan nemesek), possessed only armales, and Geörch does not refer to them as crown members. Further on he notes that Art. 7 of I 723 ordered the counties to send nobiles possessionati to the diet: Honnyi törvény, 3 vols, Pozsony I804-09 (hereafter, Honnyi töro.), I, pp. 28, 32 and 36. A century later, however, the leading historian, Marczali, was reprimanded (see p. 496 below) for writing that Werbőczy held only the landed nobility to be members of the Holy Crown, not the rest as they did not enjoy equal liberty and had to pay tax: Ung. Verfassungs., p. 28. From the considerable recent literature on the curialists and armalists see particularly the studies of József Hudi listed in László Kósa's Hét szilvafa árnyékában, Budapest, $200 \mathrm{I}$, pp. 274-75. Kósa's work is a monograph on the social conditions of all groups of the petty nobility before i 848 . The volumes of the István Hajnal Circle, Rendi társadalom — polgári társadalom, i 987-200o (eleven volumes so far) is a storehouse of information on the subject.

221 Eckhart, Szentkorona, pp. 29 I-92.

222 '. . . qui Vobiscum una Sacrae Regni Unius Coronae comembra sunt': Felséges Első Ferencz Ausztriai császár, magyar és cseh ország koronás királyától . . . rendeltetett Magyar Ország gyûlésének Jegyzókönyve, Pozsony, i 826 (hereafter, Felséges Elsö Ferencz), p. 48.

${ }_{223}$ The government (not at all interested in democracy) by this move tried to undermine the political influence of the bene possessionati, the well-to-do gentry. See Mihály Horváth, Huszonöt év Magyarország történelméból, Budapest, I868, I, pp. 27-28, io6.
} 
extended from the possessionati to the whole body of nobility, emphatically underlining the political equality between poor and rich nobles ${ }^{224}$ as well as the separation between the noble populus and the plebs. Because of the socially exclusive character of the crown metaphor, liberals applied it less frequently to persons than their opponents. Deák did not use it all and Széchenyi ${ }^{225}$ and Eötvös ${ }^{226}$ did so only mockingly. Wesselényi and Kossuth treated crown membership with respect but they predicated the metaphor on the 'nation' (a claim which, as we shall see, was not new) and they used it to further reform (which was, however, new). Baron Miklós Wesselényi, a constitutional radical, argued in the Balitéletekról ${ }^{227}$ in I $83_{3}$ that the king's right of escheat could be removed by legislation because:

the principle is clearly expressed by the the Tripartitum in Pt. I Tit. I $^{228}$ that the true and legitimate successor of every baron and noble is the Hungarian crown by which we ought not to understand the person of the king on its own and in its particularity but the personality of the nation in its entirety which [the term] membrum sacrae coronae exhibits. ${ }^{229}$

In a manuscript composed in I833, Kossuth placed the crown concept in the service of social reform. He too believed, he started defensively, that the basic rights, summarized by Werbőczy in the Tripartitum Pt. I Tit. $9{ }^{230}$ were immutable in that they could not be taken away from the nobles, members of the Holy Crown:

But I ask what would the Hungarian noble lose from his rights if our law would declare that nobody could, without the process of law, interfere with

${ }^{224}$ By the end of the eighteenth century well over two thirds of the nobility were either curalists or armalists: Ferenc Maksay; Le pays de la noblesse nombreuse, Budapest, I 980.

225 Széchenyi in the Stadium (I838) referred sarcastically to his own condition that 'for the honour of being a member of the Holy Crown or a part of St Stephen's mantle, which is in fact not true either physically or morally, I am not an owner, however, only an usufructuarius', quoted by Eckhart, Szentkorona, p. 294. Széchenyi scoffed at the visible Crown of St Stephen as well, see quotation in Radnóti, 'Uvvegalmárium', p. 62.

${ }^{226}$ Eötvös observed in Reform (I846) that 'the Hungarian people are not only under the king of Hungary but subjected to the tyranny of the Hungarian crown's five hundred thousand members': József Eötvös in Reform és hazafiság, ed. István Fenyő, Budapest, i 978, I, p. 355. Elsewhere Eötvös referred to the 'gallant members of the Holy Crown taking up their cudgels' at elections, see ibid., p. 486. In his The Village Notary, a didactic novel from I845, the Anglo-maniac 'James' Bántornyi founds an Association for the Prevention of Cruelty to Animals but because of the Tripartitum the nobles were exempted from its oversight: otherwise 'a landed proprietor and a member of the Holy Crown would lose his high position if he were forbidden to whip his horse to his heart's content': English translation by O. Wenckstern, London, I850, 3, p. I63. The old Eötvös softened up his attitude: in I 864 he merely found 'peculiar' the crown membership idea: István Fenyő et al. (eds), Vallomásokés gondolatok, Budapest, I977, p. 586.

227 Published in Bucharest and Leipzig in I 933.

228 The king's right of escheat to landed property.

${ }^{229}$ Wesselényi, Balítéletekról, pp. 269-70.

${ }^{230}$ In the Primae nonus Werbóczy listed the four cardinal privileges of the nobility, see note 53 above. 
the Hungarian peasant, his person and possession, that he too possesses land property, that he too is a member of the nation and the Holy Crown. ${ }^{231}$

The aim of the liberal programme of creating a Hungarian civil society was to close the gap between the populus and the plebs by 'uniting in law and interest the whole Hungarian people'. ${ }^{232}$ The abolition of serfdom and the first steps made in I 848 towards legal equality were truly popular reforms that attracted the loyalty of the towns and large sections of the peasantry to the new political order. There were two other potent factors at work. The experience of serving in the nemzetórség, the militia, created by Law XXII of i 848, and later in the honvédség during the Independence War, tied masses of ordinary Hungarians to the nobility-based nation. Later, the popular song 'Lajos Kossuth sent word . . .' may have helped national integration as much as the earlier promise of legal equality. Participation in politics through the franchise at local and general elections was another factor. Here caution is in order. 'Democracy', a popular slogan in the i84os, asserted the principle of legal equality rather than that of majority rule or the conferment of political rights on the adult population. The effect of participation as an aid to political integration was, therefore, limited. Both the nemzetórség ${ }^{233}$ and the franchise ${ }^{234}$ were open only to the relatively well-to-do and the educated; service in the honvédség, although nationally divisive was, however, not.

Uncertainties over the extent of political integration after i 848 appeared in the uses of the crown membership metaphor. Imre Zsarnay, deputy alispán of Torna, argued with general support in the House at the i 86 I diet, that because the differences between the populus and the plebs had been abolished in i848, the law ought clearly to recognize 'that all citizens inhabiting the country are members of the Holy Crown' and must therefore be treated equally in penal procedure. ${ }^{235}$ Zsarnay's view was not quite shared by Emil Récsi, a leading jurist, who in his I86 I textbook connected membership of the Holy

\footnotetext{
231 The first part of the passage (to which I shall return) runs: 'The Hungarian noble is a member of the Holy Crown which is in turn, the symbol of national majesty and in this way the Hungarian noble is a part of the legislative power; he possesses the right to own land; without the process of law, not even the king can interfere with his person and possession; can freely dispose of his property, etc. All these rights rest on national majesty, which arise from the basic structure of life in society, and are therefore sacrosanct, unchangeable and indefeasible. But I ask . . . etc.': $K L O ̈ M, 6$, p. 378.

232 Preamble to the April Laws of i 848.

233 Set out in para. I, Law XXII of 1848.

234 Para 2, Law V of i 848.

235 In the debate on the committee report of the Chief Justice Conference on judicial procedure, 20 June I86I, Az országgyûlés képviselőházának naplója (hereafter, Képv. napló), 2, p. I 7o. Zsarnay in another speech also applied the metaphor to the nationalities, ibid., p. 298.
} 
Crown with the exercise of political rights. ${ }^{236}$ Perplexingly, both views survived in political discourse. The crown metaphor was used to support the introduction of general conscription in the House in the summer of I 868. The committee report on the three defence bills, ${ }^{237}$ drafted by the rapporteur, Károly Kerkápoly, argued that before i 848 all members of the Holy Crown had been obliged to perform military duties and that, because the I848 Laws 'had endowed the whole population with membership of this crown', military service had become equally everybody's duty. ${ }^{238}$ The leading 48er, József Madarász, disagreed. He pointed out that the I848 Law on the nemzetôrség had extended the obligation only to those who qualified. ${ }^{239}$ But undisturbed, Kerkároly reiterated: in I 848 all inhabitants had become members of the Holy Crown because the law in I 848 had opened the possibility for everybody to fulfil the conditions of membership. ${ }^{240}$

It was not difficult to extend crown membership to the whole population with respect to duties; it was more difficult to do so concerning political rights. Crown membership as a metaphor for the political community usually turned up in legal works and in political pamphlets in connection with the right to vote. ${ }^{241}$ Sebő Vukovics, a Left-Centre member, in the debate on the revision of the electoral system, argued in the House that until I 848 only the privileged classes had possessed the vote and thereby membership of the crown; after I 848, however, all those who were given the right to vote, the pays légal, had to be regarded as 'members of the crown in whom popular sovereignty was vested'. ${ }^{242}$ In the end, membership was neatly separated from the franchise; ${ }^{243}$ thus it might be claimed that the whole nation and the crown 'entwined with each other, according to the teaching of Werbőczy', under Franz Joseph, 'the most constitutional

${ }^{236}$ Emil Récsi, professor at the Law Faculty in Pest, Magyarország közjoga Buda-Pest, I86 I (hereafter, M. közjoga), pp. 287, 307 and 326. Per contra, the rising jurist, Károly Csemegi in a baroque flourish declared in 1862 that the I848 Laws had placed the whole nation 'in St. Stephen's heirloom': Károly Edvi Illés et al. (eds), Csemegi Károly mûvei, 2 vols, Budapest, I 904, I, p. I 30.

237 They became Laws XL, XLI and XLII of 1868.

23820 July i 868, Az országgyûlés képviselóházának írományai, 5, p. I64.

239 3o July i 868, Képv. napló, 9, p. 290.

2404 August I 868, ibid., p. 420 , see $D F B$, v, pp. 42 I-22. As minister of the crown, Kerkápoly later repeated that the Law had endowed 'millions of people' with crown membership, 8 March i873, Képv. napló, 5, p. 377.

${ }^{241}$ For example, Ignácz Kuncz, Az államélet fö́bb mozzanatai tekintettel a magyar közjogra, Pécs, I 87o, p. 62; [Elek Jakab] Tisza Kálmán, Budapest, I978, p. 68.

24224 February I872, Képv. napló, 21, p. 27 I.

243 Gyula Schvarcz, the scholar-politician, criticized the views of the jurist István Kiss on crown membership which conflicted with the principle of civil society, 'Tanulmány a magyar államjogi irodalom újabb termékeiröl', Magyar Igazságügy, 27, I887, esp. p. 352. On Schvarcz's conception of civil society see ch. 3. of György Miru's unpublished dissertation, 'Polgárosodás és alkotmányos átalakulás Schvarcz Gyula politikai gondolkodásában', Debrecen, I997. 
crown head'244 (while the franchise was kept narrow). This may have only been whistling in the dark; rhetorical flourish could not paper over political rifts. When at the height of the conflict between parliament and the crown over army rights Prime Minister Kálmán Széll, heading only a government in resignation in June I 903, surmised in the House that 'the crown had always been a part of the nation as the nation was a part of the crown', he added the real message that whenever they had parted, it had turned out to be a disaster for both. ${ }^{245}$

These passages, in which the crown was associated with the 'nation', the 'constitution' and 'sovereignty', reveal that the nineteenth-century innovations went much deeper than the social enlargement of membership.

\section{The Holy Crown, the nation and the constitution}

The shift to the vocabulary of modern politics amounted to a radical departure from Werbőczy's ideas on the uses of the Holy Crown. Antecedents went back to the eighteenth century. For Werbőczy the majestic rights resided in the Holy Crown, the royal office, and were, consequently, vested in the legitimate, crowned king. The ország, as we have seen, was also a repository of rights and it became emphatically so after ${ }_{1} 526$ in its conflicting relationship with the Habsburg crown. One manuscript pamphlet, written anonymously by a canon in I 765 , was very popular at the diet but distressed the queen so the authorities committed it to the flames in Pressburg. The pamphlet claimed that not only the king but the Status et Ordines as well were in possession of the rights that resided in the Majestas Sacrae Coronae Hungaricae. ${ }^{246}$ The radicalism of this MS could not have been an isolated case. The crown's servants and the dynasty's supporters were not idle either in drawing political conclusions from the organic metaphor. They defended the rights of the 'head' against the encroachments of the 'members'. Mihály Bencsik, law professor and authority on the Tripartitum at the University in Nagyszombat, argued that because members had to follow the head, only Catholic nobles should be recognized as members of the crown; non-Catholics, being disloyal, should be deprived of their political rights. ${ }^{247}$

\footnotetext{
244 B. Gusztáv Beksics, 'I. Ferencz József és kora', in Sándor Szilágyi, A magyar nemzet története, Budapest, i 898, io, p. 5 I 7.

245 On 25 June i 903 , Képv. napló, i 7, p. io.

246 The authorities set the police on finding the author, without success. He probably was György Richvaldszky, canon at Esztergom whose Vexatio dat intellectum, written in I 765 , was published in I 785. See Győző Concha, 'A Vexatio dat intellectum cimû röpírat I 765-ből', in Hatvan év tudományos mozgalmai között (hereafter, Hatvan év), 2 vols, Budapest, I928, I, pp. $202-\mathrm{I} 2$.

247 On Bencsik, see Eckhart, A jogi kar tört., pp. I 2-i6, idem, Szentkorona, pp. 300-o I.
} 
By and large, it was from I 790 that the rights of the diet, which Werbőczy's passage does not even mention, became connected with Holy Crown membership. The collapse of Joseph II's system marked the naturalization of a new vocabulary of law and politics. The critical innovation was the emergence of the term and the concept of the constitution itself. Hungary's educated nobles, like other élites in eighteenth-century Europe, discovered in reading Montesquieu's Esprit des lois ( I 748), a very popular book in the country, that they possessed a 'constitution' rather than just a collection of customary rights sanctified by immemorial tradition. ${ }^{248}$ The ten years' rule of Emperor Joseph II was branded as 'unconstitutional'. When in I 790 St Stephen's Crown was brought to Buda ${ }^{249}$ it was seen as the fulcrum of 'Hungarian liberty'. From this time, the Holy Grown became the palladium of the magyar nemzet's (Hungarian nation's) constitution. ${ }^{250}$ Once more, the visible and the invisible crown, combined and undistinguished one from the other, provided the referent for a new notion: the palladium of the constitution. The 'constitution', in contrast to most uses of Verfassung was, of course, a normative term. For Joseph II's rule was held to be 'unconstitutional' because he had dodged diaetalis coronation, ${ }^{251}$ a precondition of which was the taking of the Oath and the issuing of the Diploma by which royal rule became 'constitutional'.

In the same turbulent years, a largely unnoticed ${ }^{252}$ subtle shift, a reversion of sorts, occurred in political discourse concerning crown membership. Before this change the grantee or donatarius, called a noble and member of the Holy Crown by virtue of the donation, had appeared (personally or through a deputy) at the diet to make laws. After the shift, a noble by virtue of his participation in law-making was said to be with a sleight of hand, a member of the Holy Crown. This change of significance took place simultaneously with the extension of membership socially downwards, a process which I have already described. ${ }^{253}$ All in all, by the I 830 s the claim was firmly established (although not yet general) that the whole nobility, because of their political rights, were members of the Holy Crown. As the following examples illustrate, 'legislation', 'rights of majestas', 'national rights',

\footnotetext{
248 László Péter, 'Montesquieu's Paradox on Freedom and Hungary's Constitutions I 790-I 99o', History of Political Thought, i 6, Spring i 995, pp. 79-82; Éva H. Balázs, Hungary and the Habsburgs I $765-1800$, Budapest, I 997, pp. I 34-42.

249 On the movement of the nobility in I 790 see C. A. Macartney, The Habsburg Empire I 79o-I9I8, London, I 968, pp I 37-42; László Kontler, Millenium in Central Europe: A History of Hungary, Budapest, I 999, pp. 2 I 8-20.

250 Péter, 'Verfassungsentwicklung', p. 250.

251 See also p. 436 above.

252 Eckhart, however, noticed it in Emil Récsi's work: Szentkorona, p. 3 I I.

253 See pp. 463 f above.
} 
'state rights' and 'sovereignty' were incrementally associated with Holy Crown membership.

An early example of political rights being deduced from crown membership dates from I 787 . In their memorandum to the sovereign, the Transylvanian nobility, in listing their gravamina, associated their membership of the Holy Crown with their privileges and even the right to participate in legislation. ${ }^{254}$ In I8 I I the Hungarian diet took the view that the fiscus, in acting for the king, was also acting for the crown of which the estates were a part. ${ }^{255}$ At the next diet in 1825 the personalis argued from the Chair, against the estates who wanted to set up a fiscus for the ország, that the move was unnecessary because 'the royal fiscus acted for the crown which does not only include the king as its head but also the nobles of the ország as its members'. ${ }^{256}$

As we have seen, Baron Miklós Wesselényi argued in I83 I by reference to the Tripartitum ${ }^{257}$ that the king's right of escheat could be removed by legislation. ${ }^{258}$ Also, he identified membership of the Holy Crown as the 'personality of the nation'. ${ }^{259}$ Wesselényi's claim was an early example of inferring political rights from crown membership. In his political rhetoric, Kossuth made similar deductions. He wrote in a minority report in respect of the instruction of the deputies in County Zemplén in I 832:

When we look at the origins and developments of our system of legislation in historical and status terms we are convinced that not only are all nobles members of the Holy Crown, which represents all national rights and consequently they truly participate in legislation, but also that participation is every noble's right and duty. ${ }^{260}$

Later Kossuth in an unpublished MS repeated the flourish:

The Hungarian noble is a member of the Holy Crown which is, in turn, the symbol of national majesty and in this way the Hungarian noble is a part of the legislative power. ${ }^{261}$

Both examples are from Kossuth's early career. In the i 840 , the years when Kossuth rose to political prominence, he did not use crown

\footnotetext{
254 Oscar Meltzl, 'Die Gravaminal-Vorstellung des siebenbürgischen Adels an Kaiser Joseph II von Jahre I 787' (Archiv des Vereins für sibenbürgische Landeskunde, N.F., 2 I), Hermannstadt, I 887, pp. 367-440 (p. 372).

${ }^{255}$ Quoted by Ereky, Fogtört.tanulm., I, p. 390 n. I, but this is not a clear example as the office, among its other responsibilities, was dealing with fiscalitas and caducitas.

256 Felséges Első Ferencz, p. I 26; and Felséges Elsó Ferencz . . . irásai, Pozsony, i 826, pp. 6o-6 i .

This is a better example than the previous case (see note above) because the disputed point concerned the administration of justice.

257 Published in Bucharest and Leipzig in I 833.

258 Werbőczy explained fiscalitas, royal escheat in Pt. I Tit. Io.

259 Balítéletekról, pp. 269-70.

260 KLÖM, 6, p. $33 \mathrm{I}$.

261 Ibid., p. 378. For the full quotation see note 23 I above.
} 
membership in putting together his reform programme with the sole exception of the crown's territorial integrity. ${ }^{262}$ Kossuth followed general practice. However, after állam (the State) became firmly established in the vocabulary of politics during the 1848 revolutions, the relationship between korona and állam moved closer. Baron József Eötvös wrote in r 865, on the eve of negotiations with Franz Joseph, that 'we ought to steer clear of any step which surrenders the state independence of the Hungarian crown'. ${ }^{263}$ Deák in his Beitrag identified corona sometimes with the ország (in the kingdom sense), at other times with magyar állam, by which he understood the rights of the monarch as king of Hungary. ${ }^{264}$ Living in a very different mental world, a champion of municipal autonomy asserted that the people (before 1848 only the populus, i.e., the members of the Hungarian Holy Grown), through the autonomous counties, 'personally exercised supreme majestic rights'. ${ }^{265}$ The publicist István Toldy held more widely shared views: 'The "Crown" meant state sovereignty; king and nation - all nobles being members of the Holy Crown - were the bearers of this sovereignty. ${ }^{266}$ The same claim was explored further in I869 by the learned LeftCentre backbencher Ignácz Ghyczy in the House: the people were always sovereign in the constitution because the nobles, the populus, 'by being described as members of the Holy Crown, were emphatically a part of the sovereignty which inhered in the Crown'. And in I 848 the nobility, by letting everybody into the constitution, 'shared the attributes of sovereignty with the people'. ${ }^{267}$ Per contra, Sebő Vukovics, another Left-Centre politician, thought that only those who had the franchise were Holy Crown members and thereby had a share of popular sovereignty. ${ }^{268}$ Gyula Győrffy, Independentist, used crown

${ }^{262}$ For instance, in the debate on the bill on honositás (naturalization) at the diet Kossuth predicated 'legislative sovereignty towards Croatia' on the 'domains of the Hungarian Holy Crown', on 27 January i 847, KLÖM, I I, pp. 479, 480.

263 From his diary on 7 July i 865, Imre Lukinich (ed.), Báró Eötvös Fózsef, Naplójegyzetekgondolatok I864-I868, Budapest, I94 I, p. I I 9.

${ }_{264}$ Ein Beitrag, pp. I 04 and I 47; and on p. I I 2 Deák referred to the Hungarian state as 'the united will of the king and the nation'.

265 'Kunágoti' Endre Vertán, Képviseleti és önkormányzati rendszer vonatkoztatva hazánkra, Arad, I 865, pp. I 3-I 4. The author held all citizens (since I 848) to be 'members of the Hungarian Crown, that is part of the supreme power directly and personally', p. 258.

266 This work is a political history: István Toldy, Régi Magyarország, Pest, i 868, p. 233, see also p. 222.

267 On 6 July r 869 in the House arguing against the bill on the judicial power, Képv. napló, 2, pp. 38I-82. The crown was occasionally even equated with ország (an untutored view). Boldizsár Halász, Independentist, opined that the view that interkalaris revenues were the king's really meant that they belonged to the ország 'because in Hungary the king and the crown always meant the ország', on I 5 February i 870 , Képv. napló, 5, p. 355.

${ }_{268}$ On 24 February I 872 in the House, Képr. napló, 2 I, p. 27 I. 
membership in rejecting the I 867 constitutional Settlement; 269 per contra Gyula Andrássy, the Younger, praised the Settlement as it preserved 'the thousand years' sovereignty of St Stephen's Crown'. ${ }^{270}$ The Independentists who fought in the House against the government's motion to suspend the immunity of a member on their side shouted in the debate that the Minister of Defence, Baron Géza Fejérváry (in defending the motion) 'did not have the foggiest' what membership of the Hungarian Holy Crown meant. ${ }^{271}$ That might have been; was there, however, anybody else who did? ${ }^{272}$ The new political rhetoric easily crept into foreign works. The Hungarian crown, visible and invisible, represented 'national sovereignty' in the works of John Paget, ${ }^{273}$ Arthur J. Patterson ${ }^{274}$ and others.

\section{Limited versus mixed monarchy in the jurists' works}

When we leave the clumsy patchwork of political rhetoric, in which even the visible and the invisible crowns were mixed up, and turn to the jurists, we find after I790 a more orderly, slowly evolving vocabulary. Rising French radicalism in the late eighteenth century had echoes even in conservative strongholds like the Law Faculty in Pest, although heterodox writings mostly remained in manuscript

269 The deputy's point was that Law XII of I867 abandoned legislative sovereignty because it was shared with another State (i.e. Austria). But, he went on, sovereignty cannot be alienated, 'because we share that right only with the crown', on 22 March i892, Képv. napló, I, p. 3 I 7 .

270 Count Gyula Andrássy, Az I867-iki kiegyezésröl, Budapest, i 896, p. I 23.

271 On 20 Nov i 902, Képv. napló, 9, p. 57; another similar interjection on I 5 November, ibid., 8, p. 418.

272 An unsigned article which poked fun at the indulgence with which writers compared the Hungarian to the British constitution pointed out the muddle over the use of the 'crown' in political rhetoric: writers follow the British precedent, referring to the king of Hungary as the 'crown'. The injunction is frequently heard in parliament: 'Do not involve the crown in political debates', but the deputies also claim that 'they represent the nation in the crown': 'Az angol-magyar alkotmány-rokonság hazugsága', Pesti Hirlap, 3 November i go7, p. 35. Muddle over the use of 'the crown' was not a Hungarian monopoly. F. W. Maitland cautioned his students: 'There is one term against which I wish to warn you, and that term is "the crown". You will certainly read that the crown does this and the crown does that. As a matter of fact we know that the crown does nothing but lie in the Tower of London to be gazed at by sightseers. No, the crown is a convenient cover for ignorance: it saves us from asking difficult questions, questions which can only be answered by study of the statute book.' The Constitutional History of England, Cambridge, i 9 i 3, p. 4 i 8.

273 'It is almost impossible for a foreigner to conceive with how deep a veneration the Hungarians regard this crown as an emblem of national sovereignty', John Paget, Hungary and Transylvania, London, I 839 , I, p. I 53.

274 Before I 848 a noble was 'membrum sacrae coronae, a member of the Hungarian Crown, and as a representative of the original free conquerors of the land, a co-partner in sovereignty with the king': Arthur J. Patterson, The Magyars: Their Country and Institutions, London, I 869, I, pp. 253-54. 
form. ${ }^{275}$ The Latin and German works published by Professors Rosenmann, ${ }^{276}$ Schwartner, ${ }^{277}$ Cziráky, ${ }^{278}$ and Virozsil, ${ }^{279}$ the standard-setting manuals of public law until the i 86os, possessed a common conceptual outlook. Their authors were all king's men, followers of Martini. ${ }^{280}$

Karl Anton Baron Martini, highly respected jurist of the natural law school, adviser to the court and tutor to the sons of Empress Maria Theresa was a late follower of Pufendorf and of Johann Christian Wolff. Martini's university textbooks, published in the late i 760 , reveal him to have been a contractualist of rank moderate form. He held that, once transferred by the people, the power of the monarch was complete yet not unlimited. Although the people did not possess the right of resistance to the edicts of the monarch, their representatives were to be consulted on public matters. Their consent was, however, required only concerning changes in people's fundamental rights. The followers of Martini regarded Hungary a limited rather than a mixed monarchy. The distinction is crucial: in monarchia limitata (in contrast to monarchia absoluta) the king governs in accordance with the laws enacted by him after consultation with the subjects. In monarchia mixta royal power is balanced by the powers of the privileged classes; legislation is claimed to be joint and therefore monarchy is 'constitutional'. Chief Justice Cziráky waxed eloquent in rejecting the view that the forma imperii in Hungary was 'mixed'. The form of rule (imperium) was purely monarchic, ${ }^{281}$ but the powers of government (regimen) were restricted by the

${ }^{275}$ Eckhart found an early example of the deducing of political rights from crown membership. Antal Demjén, Professor of Natural Law in Pest, in a MS from I 783 which the Staatsrat did not allow to publish, inferred from Werbőczy (Trip., Pt. I Tit. 3) that the nobles, as members, are connected to the monarch, as head, 'in ordinandis administrandisque negotiis publicis': Eckhart, Szentkorona, p. 30 I n. I 3; idem, A jogi kar tört., pp. I 46-49. ${ }^{276}$ Stephan Rosenmann's work was based on manuscripts by József Ürményi, High Court judge and Chief Justice, and György Lakics, law professor in Pest: Fus publicum regni Hungariae, Vienna I 79 I (hereafter, Fus publ.); its German abridged translation: Staatsrecht des Königreichs Hungarn, Vienna, I 792.

277 Martin Schwartner, Statistik des Königreichs Hungern, Pest, I 798 (hereafter, Statistik).

${ }^{278}$ Cziráky, Conspectus (see note i 8 I above).

279 Anton Virozsil, Juris publici regni Hungariae, 6 parts, Buda, I850-1 854 (hereafter, Juris publ.); idem, Magvarország nvilván-vagy közjoga, Buda, I86 I (hereafter, M. orsz. közjoga); idem, Das Staats-Recht des Königreichs Ungarn, 3 vols, Pest, I 865- I 866 (hereafter, Staats-Recht). Efforts to publish a university textbook on Hungarian public law were unsuccessful between i $79^{\circ}$ and I848. The court carefully guarded the crown's sovereignty claims which were not entirely endorsed even by 'establishment men'. Virozsil wrote his Latin work in I 843 but the authorities did not allow its publication at the time. Cziráky's work (written in the I 83os) received the same treatment. The fact that he was Chief Justice and the doyen of the profession and that Virozsil was the rector at the University of Pest made no difference. Both works were allowed to be published after 1849 as historical accounts.

280 The authorities were afraid of the influence of Kant's works. The Gubernium ordered in I 795 the University to use Martini's works, where it was possible, in teaching: Eckhart, $A$ jogi kar tört., pp. 230-3 $\mathrm{I}$.

${ }_{281}$ Cziráky, Conspectus, 2, pp. I 86-88, 'omnis civilis Imperii Majestas, omnisque plenitudo potestatis in una Ejusdem Persona resideat', p. I 88. 
laws, made with the consent of the diet, which the king had inherited. ${ }^{282}$ Virozsil, like Cziráky, expressly rejected the claim that jura maiestatica, being divided between the king and the estates, formam ... imperii $e$ monarchica et aristocratica mixtam concipiunt. ${ }^{283}$

As we should expect, crown membership did not have a prominent place in the works of the royal jurists. Rosenmann used the Tripartitum to support Martini and the court's position that Hungary was a monarchia limitata. The monarch's dispositions were not based on personal will; they were limited by laws to which the diet had freely consented. Thus Werbőczy, he went on, appropriately called the nobles members of the Holy Crown. ${ }^{284}$ It followed that the Regni Hungariae corpus politicum consisted of the king as head and the nobles as members whose cooperation and harmony were necessary for the survival of the body. ${ }^{285}$ No political conclusion followed from the exhortation. Schwartner, taking a very strict line on Majestas-Rechte, emphatically stated that unless there was firm evidence in law to the contrary, all rights of the king Reservatrecht sey, ${ }^{286}$ that is, they lay outside the competence of the diet. He barely mentioned crown membership let alone drew any political conclusions from it. ${ }^{287}$ Cziráky, although less strict on the king's jura reservata than Schwartner, was as indifferent to using crown membership for political points as his predecessors. ${ }^{288}$ Virozsil repeated the injunction in strict form that the king's majestic rights were restricted only on the basis of strong legal evidence; the presumptio juris was on the side of the monarch. Like his predecessors, he briefly mentioned crown membership, but he did not use this to make claims, although it clearly emerges from the references that those who

\footnotetext{
282 Ibid., pp. I 89-9o.

${ }^{283}$ Virozsil, furis publ., Pt. 4, pp. I 3 - I 4 .

284 'Dass die Regierungsart von Hungarn monarchisch sey, wird leicht keiner in Abrede stellen, da die ganze oberste Gewalt in der Person des Monarchen vereinigt ist, so, dass in den, die öffenliche Verwaltung und das ganze Königreich betreffenden Angelegenheiten, ohne seinen Beitritt und seine Einwilligung, nichts giltig entschieden werden kann; dass sie aber auch eine beschrankte Monarchie sey, ist aus dem abzunehmen, weil die Könige in öffentlichen Reichsangelegenheiten nicht nach ihrer Willkühr handeln und entscheiden darfen, sondern an die landtagsmassige Einwilligung und freiwillige Beistimmung der Stände gebunden werden. Daher sagt Werbőz granz anpassend: dass die Edelleute durch eine gewisse Reziprokazion und wechselseitige Verbindung mit dem Königen, als Glieder der heiligen Krone geachtet werden, die, ausser dem rechtmässig gekrönten König, keinem anderen unterworfen sind.' Rosenmann, Staatssrecht, Pt. 2, para. I. Idem, Fus publ., pp. $30-3 \mathrm{I}$.

285 Quoted by Eckhart, Szentkorona, p. 303.

286 Schwartner, Statistik, pp. 347-48. In the second edn (2 vols, I809-I8 I I), he referred to Hungary as 'eine erbliche aber eingeschränkte Monarchie', 2, p. I.

287 Ibid., p. 365.

${ }^{288}$ Cziráky, Conspectus, Pt. 2, p. 6 and Pt. I, p. I 32.
} 
appear at the diet were called members of the Holy Crown because they participated in politics. ${ }^{289}$

Jurists representing the views of the nobility, rather than being directly dependent on the government, begged to differ from the royal jurists. They regarded Hungary as a constitutional rather than a limited monarchy. In essence, this principle was what the 'movement' of the nobility in I 790 was about. Even when they conceded that monarchy in Hungary was 'limited', they went on to argue that in fact it was 'mixed'. Their mental world, medieval and dualistic, was inhabited by two actors: king and ország. Albert Barits, the university teacher, and György Aranka, judge in Transylvania, argued in their anonymous publications in I 790 that 'the supreme power is divided between king and ország'. ${ }^{290}$ Illés Geörch reckoned that the laws were made by the four status et ordines, empowered to legislate at the diet, which the king then had only to approve and render authentic by personal signature. ${ }^{291}$ Any royal jurists would have dismissed, as untutored, the very first sentence after the introductory parts of Zsigmond Beöthy's Public Law: 'The kormányalak [form of government] in Hungary is monarchy restricted by the estates of the ország. ${ }^{\prime 292}$ The author then gave a potted history of the fundamental laws as agreements between the two actors and concluded on the point that the kormányalak was really 'monarchoaristocratic' in which the single ruler 'shared' power with the few, the aristocracy. ${ }^{293} \mathrm{~A}$ moderate man, Beöthy inferred from membership of the Holy Crown only the injunction of fidelity to the king and the crown. ${ }^{294}$ Károly Miskolczy's outlook was similar to Beöthy's but his interest in the Holy Crown was confined to the fiscal and the territorial senses. ${ }^{295}$

${ }^{289}$ Virozsil, Furis publ., Pt. 2, p. I I. Ibid., Pt. 4, p. I6; idem, M. orsz. közjoga, pp. 68 and I49; idem, Staats-Recht, I, p. 282, 2, pp. 256-59. Jurists after the 1867 constitutional settlement followed Virozsil. Ignácz Kuncz noted that because the ultimate source of political rights was the state, the Hungarian noble was adorned by the splendid title of the Holy Crown's member. Kuncz, at the same time, departing from Virozsil, tried to soften the implications, not very successfully, of the monarchic reservata: Az államélet fóbb mozzanatai tekintettel a magyar közjogra, Pécs, I87o, pp. 62, 99-103.

${ }^{290}$ Quoted by Győző Concha, Politika, 2 vols, Budapest, I895, I, p. 298. On Barits see Eckhart, A jogi kar tört., pp. 208-I2. There is some doubt over the authorship of the work attributed to Barits.

${ }^{291}$ Geörch, Honnyi töro., I, pp. 4-5.

${ }^{292}$ Zsigmond Beöthy, Elemi magyar közjog, Pest, I 846 (hereafter, Közjog), p. I4. The author was szolgabíró in County Komárom.

${ }^{293}$ Ibid., p. I 5 . The claim that the 'nation' shared the majestic rights with the king was common currency in lectures at the Hungarian Academy in Pest. See, for instance, Antal Sztrokay, 'A Magyar álladalmi szabadság jogi szemléje', in Magyar Tudós Társaság Évkönyvei, 'Értekezések', 7, i 846, pp. 3-1 7 (p. 7).

294 Beöthy, Elemi magyar közjog, p. 66.

${ }^{295}$ Károly Miskolczy, Magyar Ország köz foga, Eger, i846. The author was a solicitor. After declaring that the form of government in Hungary was monarchia limitata, Miskolczy went on to argue that power was transferred 'on conditions' and that legislation was 'joint': pp. I $3,4^{-}-4$ I. 
The subject suddenly took off with Béla Szabó, a judge in County Moson, whose treatise, written in I 847 , was published during the 1848 revolution. His individual political system was based on two propositions, both argued on historical grounds. The first was that the Lands of the Hungarian crown formed an álladalom entirely independent of Austria, which was likewise an álladalom. ${ }^{296}$ The second contention of Szabó was that the Hungarian crown was the true owner of all the lands within the Hungarian álladalom, a thesis from which he boldly deduced a whole set of other principles. Individuals could only 'possess' (rather than own) property in the álladalom. ${ }^{297}$ In it, a single Hungarian nation (the nobility) had existed in the past and should (in a new form) exist in the future. ${ }^{298}$ The king, too, was only a 'possessor' of power, the országol, on the strength of pactum conventum with the nation, while sovereign power, following from its ownership of all the lands, was settled on the crown of which the possessors of land were members. The members of the crown were not even 'subjects' (Untertanen) of the king. ${ }^{299}$ As Győző Concha, politics professor in Budapest, pointed out in a perceptive, critical essay, Szabó, by mixing up property relations and the question of sovereignty, confused private law with public law. ${ }^{300}$ Szabó, the Filmer of the Hungarian nobility, was overtaken by the revolution and the subsequent recentralized Austrian system. Szabó's monograph remained an isolated work seemingly without influence either on politicians or jurists until it was discovered by Concha, the true maker of the Holy Crown doctrine, who gained inspiration from it. ${ }^{301}$

Unexpectedly, membership of the Holy Crown turned up in a legal case in London. In the Hungarian Banknote Affair of I86I, the well known constitutional writer Joshua Toulmin-Smith went to the defence of Kossuth who had arranged the printing of paper money for Hungary in his own name. The Austrian government took him to court in

\footnotetext{
296 Béla Szabó, A magyar korona országainak státusjogi és monarchiai állása a pragmatica sanctio szerint, Pozsony, I 848 (hereafter, A. m. korona), pp. 5 f., 29f., 5I, I 2 I, I 36 . The author was a landowner and solicitor, absentium legatus at the diet in $183^{2-} 36$, juratus assessor in Counties Győr and Moson and a follower of Kossuth in I 848 .

297 Ibid., pp. 73-74.

298 Ibid., pp. 6of., I $57-58$

299 Ibid., pp. 29, 5 I, 80-84, I I 2- I 4 .

300 Győző Concha, 'Szabó Béla elfeledett közjogászunk' (igr8), repr. in Hatvan év, 2, pp. 496-5 I 9, 5 I 5

301 Concha regretted that Szabó's work had been forgotten for so long since it made an original contribution to Hungarian legal thinking 'by giving a clear interpretation to what the attribution of sovereignty to the Holy Crown, as had been expounded by Werbőczi, involved': ibid., pp. 497, 50o. Concha's first reference to Szabó's 'valuable work' was from I 89 I (see Hatvan év., I, p. 639), the year when he constructed the Holy Crown doctrine, see page 48 If. below.
} 
London. ${ }^{302}$ In order to win public support for Kossuth, Joshua Toulmin-Smith, a political friend, agreed to the publication of his letter to the Foreign Secretary ${ }^{303}$ in which one of the arguments to justify the printing of the banknotes was:

It is written, then, among the fundamental laws of Hungary, that every Hungarian noble has a share in the Sacred Crown of Hungary, and that none is above him but the lawfully crowned King. Kossuth is a Hungarian noble: he has therefore the full right to put the figure of the Hungarian Crown on any document or anything else that he pleases.

In a footnote to the paragraph, Toulmin-Smith even attached chapter and verse from the Tripartitum. ${ }^{304}$ Not unexpectedly, the High Court found against Kossuth and his associates. ${ }^{305}$

Only one or two works moved the subject further from the spate of publications on public law after the collapse of the 'Bach regime', the easing of government control and the enactment of the October Diploma in I86o. Emil Récsi, professor in Pest, produced an independent work. In his Public Law he sought to have it both ways. The 'Hungarian state body' was a 'limited monarchy' in which, however, the monarch's rights faced the nation's which 'bear on the exercise of the same supreme power'; from their mutually restricting balance a 'constitutional system' emerged. ${ }^{306}$ Récsi emphatically stated that the nobility (before I848) were called members of the Hungarian Holy Crown because they 'participated in the exercise of the supreme, notably legislative power at the diet'; ${ }^{307}$ however, since the I848 Laws, all

${ }^{302}$ In order to finance a revolutionary war against the Habsburg Emperor so that an independent Hungarian State could be established, Kossuth, then an émigré in London, commissioned a firm, W. Day \& Sons, to print r oo million forints in paper money with his name as Governor of Hungary and the Hungarian coat of arms on it. After the money had been printed by the firm the Emperor of Austria brought an action against W. Day \& Sons and Louis Kossuth on 29 February i 86 I. The case was heard in the Court of Chancery. See Erika Garami, 'Louis Kossuth's banknote issue and legal case in London in I86r', in Virginia Hewitt (ed.), The Banker's Art: Studies in Paper Money, London, I 995, pp. 38-45.

${ }^{303} \mathrm{~J}$. Toulmin-Smith: Who is the 'King of Hungary', that is now Suitor in the English Court of Chancery?' A Letter to the Right. Hon. Lord 7. Russell. M.P. (London, I 86 I ). Kossuth writes in his memoirs that he arranged for 3000 copies of the letter to be printed. These were then sent to all MPs, newspaper editors and various institutions. See KLI, 2, p. 442.

304 See note 303 above. Toulmin-Smith: p. I 2 and $n$.

305 The case was won by the Emperor (4 May). The defendants appealed to the Lord Chief Justice. The Lord Chancellor, however, dismissed the appeal on I 2 June I 86 I. The printed paper money (weighing about 20 metric tons) was then destroyed. The Emperor of Austria v. Day and Kossuth. Before the Lord Chancellor Lord Campbell and the Lords Justices. 22, 23, 24 May, 7 June i 86 I; and see KLI, 3, pp. 7 I-79, 366-507.

306 Récsi, M. közjoga, pp. I 24, see 230 and 439. In his Public Law, Mihály Boross, formerly alispán of County Fejér, a local judge, argued that, although a limited monarchy, in Hungary 'the exercise of complementary and mutually restricting monarchic and national rights make up the constitution', Magyarország közjoga I848-ig s I848-ban, Pest, I 867, p. 27.

307 Récsi, M. közjoga, p. 287. Récsi also held that the Hungarian crown united 'various nations' who all benefit from it, 'if they all equally revere the authority of the single legislature and the Hungarian crown which represents the unity of the Hungarian köz állodalom', p. 3 I 4 . 
citizens were legally eligible to acquire the franchise. ${ }^{308}$ The leading Hungarian authority on public law in Transylvania, Elek Dósa, defined the legal relationship between the prince and the people as constitutional, based on the principle of mutual rights and obligations. ${ }^{309} \mathrm{On}$ the Holy Crown, however, Dósa had no original ideas except the observation that civil society, as a concept, was realized in the Holy Crown and consequently the crowned prince. ${ }^{310}$ More originality was shown by Károly Cisemegi, a leading jurist, who used crown membership in I 862 to rebut the so-called Verwirkungstheorie which claimed that Hungary had forfeited her constitution in I 849. According to Gsemegi, the theory could not apply to Hungary, since Hungary was a 'constitutional monarchy based on the sovereignty of the State'. The membra sacrae coronae, in addition to their strictly legislative function, were also empowered to participate in other governmental acts. Thus, 'the great question of sovereignty, which today is so hotly debated in other countries, was settled with us by the precise disposition of the law centuries ago, as the attribute of the crown'. ${ }^{311}$ Before I 848 the right of the crown was exercised by 'the Holy Crown as a whole' which included the king and the nobility and, after I 848 , the whole nation. ${ }^{312}$

The 'crown as whole' apparently haunted other scholars as well until the legal historian Imre Hajnik supplied the phrase. He wrote in r 875, that is a few years after the I 867 constitutional Settlement, in his General European Legal History:

Only where, as in the diet, the monarch wearing the crown on his head appeared together with the members of the Holy Crown was the whole body (totum corpus sacrae regni coronae) present, that is public power in its entirety. Only under these conditions could the Holy Crown exhibit its capacity to the full and could law be made. And finally, the Holy Crown and its members developed the governmental relations on which the autonomy of the Hungarian state is, in particular, dependent. ${ }^{313}$

\footnotetext{
308 Ibid., p. 326.

309 Elek Dózsa, Erdélyhoni jogtudomány, 3 vols, Kolozsvár, i 86 I, I, pp, I I 7- I 8.

310 Ibid., I, p. 56. Dózsa had the land donation in mind, see 2, p. $25^{8}$.

311 'A jogvesztés elmélete és az államjog', in Csemegi Károly mûvei, 2 vols, Budapest, I 904, I (hereafter, Csemegi), pp. I 26-27. Csemegi was arguing against minister Schmerling's statement in the Reichsrat, made on 23 August i 86 I. See Josef Redlich, Das österreichische Staats-und Reichsproblem, 2 vols, Leipzig, I 920-I 926, 2, p. I 57.

312 Csemegi, p. I 30.

313 Imre Hajnik, Egyetemes európai jogtörténet, Budapest, I 875 (hereafter, Egyet.jogtört.), p. 2 I o; also quoted by Eckhart, Szentkorona, p. 3 I 9 . The passage was repeated without any revision in all the five editions of the work (fifth edn, I899, p. 237).
} 
Many a historian since the First World War has been looking for totum corpus sacrae regni coronae in the sources without, however, coming up with a single example. ${ }^{314}$

Hajnik referred to the 'public law character' of Hungarian constitutional development as the 'doctrine' of the Holy Crown, and historians have ever since regarded him as the discoverer of the 'doctrine'. ${ }^{315} \mathrm{~A}$ distinguished historian of medieval European institutions, Hajnik insisted that Hungarian institutions could be understood only in this wider context. His influence was undoubtedly important; a strong case could be made, however, that he was not the author of the Holy Crown doctrine. A conservative scholar, Hajnik, like others, understood by supreme power, or sovereignty, the legislative independence of Hungary as a state. He was not concerned with the king's rights, which is what the doctrine was about. Politically a follower of Deák, Hajnik never argued that parliament had the right to initiate legislation on any subject that the I867 Settlement had recognized as the monarch's reservata. The doctrine as it has been asserted and used in constitutional discourse was the product of the so-called dogmatic law school, which appeared in the $\mathrm{i} 880 \mathrm{os}$ in association with the work of a young jurist, Ernő Nagy. ${ }^{316}$

The making of the doctrine of the Holy Crown

Nagy's Public Law (I887) ${ }^{317}$ represented a new method; indeed its author established a new school. The 'Hungarian Laband', as Nagy was soon called, learnt German analytical jurisprudence, the so-called dogmatic method, in Strasbourg. Paul Laband, the most influential lawyer of the German imperial system of government, who became professor in Strasbourg in I872, was an analytical jurist concerned with the general qualities of existing law. While adherents of the 'historical method' frequently treated the existing law as a mere adjunct to what had historically evolved, the followers of the analytical method examined the legal concepts of the present and used the past to

${ }^{314}$ Hungarian jurists and some historians, following Hajnik, went on referring to the 'total body of the Holy Crown' ad nauseam without producing a single instance in the documents. The lack of the evidence was pointed out by József Barabási Kun, 'Széljegyzetek a szent korona tanához', Budapesti Szemle, i 72, I 9 I 7 (hereafter, 'Széljegyzetek'), pp. i6-53 (p. 26). The subject was critically examined by Bartoniek, 'Corona', esp. p. 328. She found totum corpus predicated only on regnum.

${ }^{315}$ Hajnik, Egyet. jogtört., p. 208 Eckhart wrote that Hajnik's works provided 'the starting point of the new understanding of the doctrine'. Hajnik undoubtedly regarded the corporate crown as central in the working of the political institutions when others did not. Yet his ideas on the crown were very similar to Récsi and Csemegi's apart from contriving the totum corpus phrase - an aberration in the work of a respectable historian.

316 See Péter, 'Verfassungsentwicklung', pp. 386-97.

317 Ernő Nagy, Magyarország közjoga (államjog), Budapest, i 887, seven edns (hereafter, Közjog). 
supplement it. As critics of this school liked later to point out, the jurists of the new method 'discovered' modern legal categories in the legal material of the past. Nagy applied the new method vigorously to the Hungarian constitution which had hitherto been superabundant in historical material. In his textbook he gave clear definitions of legal categories like the State, public law, sovereignty and others. Following German jurisprudence, inspired by Hegel, he defined the state as an entity with the attributes of 'personality'. The State possessed individuality, free will, ability to act and develop. Because it determined its own norms, the State was a legal person in the highest sense rather than just a 'mechanical compound of the state members'. From this it followed that 'the subject of state power had to be the state itself'. ${ }^{318}$ Problems lurked. Did Hungary possess a state personality jointly, as Siamese twins, with or separately from Austria? Did support exist in statutory law for the claim to separate Hungarian State sovereignty? Besides, the juridical nature of the 'common' monarch's rights was a contentious subject. Legal history seemed to be on the side of the leading jurists before 1867 who were unanimous in distinguishing the reserved from the shared monarchic rights and who invested the presumptio juris in the former. ${ }^{319}$ Jurists of the lower courts in the counties did not share these views. Sometimes they even claimed that the king possessed only specific powers transferred to him by the nation: ${ }^{320}$ royal power after all was based on the 'ország's crown'. We have seen earlier, however, that the 'ország's crown' had nothing to do with the extent of the king's rights. The crown belonged to the ország only in the sense that the diet acquired the right in the late Middle Ages to elect the king when the predecessor failed to leave behind a legitimate male successor (developments that were later reversed). ${ }^{321}$

In the first edition of his work Nagy asserted (although without legal evidence) the principle that Hungary and Austria were two separate states, each with unimpaired sovereignty. Somewhat incongruously, however, he reiterated the traditional distinction between the reserved and the shared rights of the emperor-king. ${ }^{322}$ When he was criticized for this by the scholar-politician Gyula Schvarcz, Nagy, in the second

318 Ibid., second edn, I89i, pp. I-3, and I50. More later on 'organic', the new vogue word among jurists.

319 See p. 47 If. above.

320 This was difficult to argue as the Pragmatic Sanction (and the Tripartitum) maintained that the rights of the crown were transferred to the king regendam et gubernandam: Art. 2, I 723 , $\S 7$. See also, Péter, 'Verfassungsentwicklung', pp. 259-6o.

321 See pp. $445^{-46}$ above. From $\mathrm{r} 687$ (at the latest), Hungary reverted to a hereditary monarchy.

322 The existence of the two separate actors, monarch and parliament, in the working of the constitution was institutional fact. The reserved rights of the emperor-king could not go along with the concept of the sovereign Hungarian State: they tied Austria and Hungary together as Siamese twins. 
edition of his work (I89I), accepted his odd advice that it was only in I 848 that the laws introduced this division of the supreme rights between the absentee king and the palatine. However, he went on, Law VII of I 867 had rescinded the palatine's power and therefore the division of the supreme rights was no longer justified. Nagy got himself into deeper trouble over this revision which, together with much else written in his manual, Győző Concha attacked. ${ }^{323}$

We should digress now from the jurists in order to uncover a political innovation which brings into focus their debate. A critical change took place during the Great Defence Debate of I 889 in which parliament challenged the king's reservata. From then onwards, Hungarian politics became a terrain of volcanic eruptions. Count Albert Apponyi's magnetic personality and oratorial brilliance helped to create a new political outlook in parliament which rejected the claim that Franz Joseph possessed reserved rights concerning the language of the army. ${ }^{324}$ The crux of Apponyi's argument was that, amidst shattering screams of approval in the House, he reversed the presumption of the law on reservata: the onus of proof was with the king rather than with parliament. ${ }^{325}$ Although formally representing a minority in the House, Apponyi won the day. Teofil Fabinÿ, Minister of Justice, after manfully defending the monarch's army rights in the House, resigned from office. $^{326}$ The outcome of the Great Defence Debate was the background and the context for the creation of the Holy Crown doctrine. The debate over the second edition of Nagy's textbook provided the occasion. ${ }^{327}$

\footnotetext{
${ }^{323}$ See Péter, 'Verfassungsentwicklung', p. 397. Gyula Schvarcz's criticism was recently reprinted by György Miru, Schvarcz Gyula, Budapest, 2000, pp. I 50-5 I.

${ }^{324}$ Ibid., pp. 52 If. We ought to remind ourselves that an Apponyi speech never merely restated constitutional principles; this magician's speech-act, or 'performative' to use J. L. Austin's term, could transform his audience's perception of reality.

325 'The extent of monarchic rights fluctuates', he began the argument, and soon came to the point: 'anybody who claims that a subject exclusively belongs to His Majesty, according to our existing public law, has to offer strict evidence. The onus of proof rests [...] on those who claim that a particular subject does not belong to the joint competence of king and nation, i.e. legislation', 2 March I889, Képv. napló, 9, p. I 76. Because of the customary character of the constitution, 'proving' a point in question (by either side) was far too delicate. The reversal of the (traditional) presumptio juris, potentially amounted to a rejection of most reservata.

${ }^{326}$ Further, Fabinÿ's successor was none other than Dezső Szilágyi, Apponyi's guru on constitutional principle. See Péter, 'Verfassungsentwicklung', pp. 323-26. Szilágyi (member of the House from I87 I, professor of law in Budapest from I874 and joint leader with Apponyi of the Moderate Opposition between I878-i 886) did more than anybody else to naturalize the vocabulary of the German dogmatic law school in parliament in the 1880 s before Ernő Nagy and the other jurists' changeover.

${ }^{327}$ Eckhart mentioned briefly the army rights as a background to Timon's book (see further: Szentkorona, pp. 325-26). He assumed that the author of the doctrine was Hajnik and that Concha only 'vindicated' Hajnik's ideas (we shall presently see that Concha did much more than that): ibid., pp. $325^{-26}$ and 320.
} 
In I89 I, Győző Concha, professor of Politics in Budapest, sharply criticized Nagy's Public Law, and indeed attacked the author himself, for Nagy, Concha claimed, slavishly followed foreign authors, particularly Laband, and 'in order to make our public law appear modern and juristic had sacrificed its specific Hungarian character'. Nagy's definition of the personality of the State led his analysis nowhere; his use of terms were confusing. He failed to grasp that in Hungary the powers of the king and the nation were for centuries intertwined to a degree found nowhere else: the ancient constitution, through the participation of the diet and the counties in the exercise of sovereignty, possessed the 'nature of public law'. ${ }^{328}$ Concha did not explore this point to which he returned only in his rejoinder. Instead he moved on to Nagy's other mistakes, of which there were many, and finished his review with Nagy's 'most glaring mistake': his failure to realize that the king's reserved and the shared supreme rights had always been distinguished from each other. ${ }^{329}$ Again Concha did not elaborate the point. Nagy was on the defensive in his Reply. As he explained, his book was only the first attempt to apply the dogmatic method to Hungarian public law and was not intended as a definitive work. Yes, he adopted the basic concepts of modern jurisprudence, but was not a slavish follower of foreign scholarship. While he learnt much from Laband, he rejected many of his ideas. The tenet of the personality of the State was, of course, much older than Laband's theories and at any rate it had acquired general acceptance in the literature. 'It is possible to talk about specific Hungarian doctrines only where specific Hungarian institutions exist', but even these have to be analysed by the methods of modern scholarship which were international. Nagy rejected point by point Concha's innuendo that he had failed to bring out in his analysis the individual features of the Hungarian constitution. He did not take on Concha's larger claim, however, concerning the nature of supreme power in Hungarian public law and was rather evasive on the distinction between the reserved and the shared rights. ${ }^{330}$

Concha, irritated by Nagy's Reply, produced a fifty-page rejoinder. ${ }^{331}$ This writing rather than, as Ferenc Eckhart had thought, Hajnik's Legal History should be regarded as the first exposition of the Holy Crown

\footnotetext{
${ }^{328}$ Győző Concha, 'Magyarország közjoga' (I 89 I) reprinted in Hatvan év, I, pp. 553-67 (hereafter, 'Magyarország közjoga'). Concha supported this claim with a passage from Werbőczy (Trip., Pt. II, Tit. 3), pp. 558-59.

${ }^{329}$ Ibid., p. 567 .

330 Ernő Nagy, Válasz közjogi könyvemról ... megjelent birálatra, Budapest, I89 I, pp. I- I6. Rather confusingly he had written in his textbook: 'The crowned king, is in his own right, the head of the Hungarian state, the possessor of supreme power.' Nagy, Közjog, I89 I, p. I 66.

331 Győző Concha, 'Közjog és magyar közjog', Hatvan év (hereafter, 'Közjog'), I, pp. 568-6 I8: a storehouse of new interpretations across Hungarian public law.
} 
doctrine. Concha found vacuous the axiom that the subject of state sovereignty had to be 'the State itself' ${ }^{332} \mathrm{He}$ deftly combined the old simile of the king as 'head' and the nobility (later the electorate) as 'members' with the modern idea of legislative sovereignty: the single supreme authority which possessed the legally unfettered right to make and unmake law. At first sight the following passage may not look all that different from Récsi, Csemegi, and Hajnik's statements. A closer look at it, in conjunction with other passages, however, reveals the differences:

In Hungarian public law the subject of sovereignty is the Holy Crown. The king becomes the participant of sovereignty through formal investiture with the symbol of that crown and the citizens do so by becoming its members, in former times through ennoblement, today through enfranchisement. Foreign jurists, by casting aside centuries-old patrimonialist views, today, nearly three hundred years after Grotius, ${ }^{333}$ hold that the subject of sovereignty is neither the ruler nor the people but the State. But, for centuries, this has already been expressed in Hungarian public law through the concept of the crown. ${ }^{334}$

Concha's evidence consisted of the joint law-making by king and diet, the monarch's obligation to enact the Inaugural Diploma and the passage from Werbőczy about the 'reciprocal transference and mutual connection' between the king and the landed nobility, the 'members of the Holy Crown' ${ }^{335}$ As we have seen, however, the passage in the Tripartitum, Pt. I Tit. 3 , had referred to the principle of equality within the landed nobility and the land donation system. ${ }^{336}$ Concha, with a sleight of hand, converted Werböczy's 'mutual connection' to the doctrine that king and parliament were 'joint possessors of legislative sovereignty'. The modern theory of the State was, perhaps incongruously, adjusted to medieval Doppelpoligkeit. It could be objected that if supreme authority resided in king and parliament, the Holy Crown doctrine was a statement on joint authority, which existed only so far as the monarch and parliament were in agreement, rather than a statement on legislative sovereignty which presupposed a single source of authority. For all this, Concha's understanding of sovereignty, based on the assumptions of the dogmatic school, radically differed from

\footnotetext{
${ }^{332}$ Ibid., pp. 585, 59 If.

333 Concha referred to Grotius here probably because he had viewed the State as a legal person rather than because of his contribution to the theory of sovereignty which, compared to Bodin and others, was slight. See Győző Concha, Politika, 2 vols, Budapest, I 895 (hereafter, Politika), pp. 235, 255f., 258.

${ }^{334}$ Concha, 'Közjog', pp. 585-86. The force of this claim is, however, weakened by another passage in which Concha admits that before the I 848 laws, 'the unity of the Holy Crown was insecure' because 'the king and the diet faced each other, in many respects, as two separate supreme powers', p. 6i5.

335 Ibid., pp. 586-90.

${ }^{336}$ See above p. $45^{\circ}$.
} 
Csemegi and Hajnik's. They had asserted the principle that the Hungarian legal system was not subordinate to any other: it was legally independent. For Nagy and Concha (and Apponyi), however, sovereignty, more than just independence, was a necessary attribute of the State in possessing unrestricted and legally illimitable supreme power in the making and unmaking of law.

An essential part of Concha's argument was that the functions of the state (legislative, executive and judicial) had to be clearly distinguished from the 'organs' of the state (which Nagy failed to do). The functions and the organs did not coincide. ${ }^{337}$ The king, parliament and the ministry constituted the three chief organs of sovereignty. Treating the ministry as a separate organ, on a par with the other two organs of the state, was a realistic assumption. The concept of organs, with its radical implications as to the nature of the king's rights, was a part of the metaphysical theory of the State which began to affect a few Hungarian jurists who read too many German authors influenced by Fichte and Hegel's writings. They certainly influenced the adherents of the dogmatic law school, notably Ernő Nagy and Győző Concha. They both claimed that the State, an end itself, an 'independent' being, indeed, a person in a legal and moral sense, was 'organic'. The term, the new buzzword, became commonplace among Hungarian jurists in the late nineteenth century. Concha, however, one of the very few who read and perhaps even understood Hegel, was the first who explored the speculative context of the organic vocabulary. For him 'organ' was 'a part of vegetal or animal body, differentiating itself from the rest of the body, which performs certain specific tasks'. ${ }^{338}$ The functions and organs of the State were only necessary elements, 'moments' of state personality. ${ }^{339}$ Hegel's direct and, through Lorenz von Stein, indirect influence is transparent. ${ }^{340}$ Organs could not will for themselves (only the whole body could), the king as an 'organ' of the State (Concha was the first to make the inference) did not possess, even as regards the reservata, a 'will' separable from the personality of the State. Nagy, according to Concha, had failed to grasp that although unlike the shared monarchic rights, the reserved rights had always been exercised

\footnotetext{
337 Concha, 'Magyarország közjoga', pp. 554-57; Concha, 'Közjog', pp. 59 I-6oo.

338 Ibid., p. 598.

339 'mozzanat': See Concha, Politika, i, pp. 272 f.

340 Hegel's organic State does not have 'head' and 'members'; its parts are 'aspects' or 'moments', analogous to the cells of animal organisms: 'Life is present in every cell. There is only one life in all the cells ...' (para. 276A). Hegel expressly rejects the feudal state, an artificial person, which was 'rather an aggregate than an organism' (para. 278). Concha may have been inspired by Hegel's prescription that in the Crown 'the different powers are bound into an individual unity, which is thus at once the apex and basis of the whole, i.e. of constitutional monarchy' (para. 273): T. M. Knox (ed.), Hegel's Philosophy of Right, Oxford, I $95^{8}$ (the paragraph numbers are Hegel's). Concha was a student and an admirer of the jurist Lorenz v. Stein, professor in Vienna, a follower of Hegel.
} 
by the king through the government without parliament's involvement, he and parliament were, as they had always been, competent to legislate on any subject, including the reservata. Concha then let the cat out of the bag. He re-counted the 'mistake' made by Teofil Fabinÿ who, as Minister of Justice, had denied that parliament could legislate on reservata and was forced out of office. In Britain, the monarch's prerogative was converted into the nation's; in Hungary the king's reservata became the rights of the Holy Crown. ${ }^{341}$ Concha's throwaway line on minister Fabinÿs resignation was a direct reference to the conflict between the Tisza government, defending the army rights of the crown and the Opposition, the Independentists and, above all, Count Apponyi, an outcome of which was the doctrine itself. The resignation of Fabinÿ on 9 April I 889 (totally overlooked by historians), was the harbinger that marked the onset of permanent instability in Dualist Hungary's politics.

The organic vocabulary of the State sheds light on our contention that Eckhart was wrong to regard Hajnik, rather than Concha, as the author of the Holy Crown doctrine. What Concha meant by organic had little in common with what Hajnik meant by totum corpus sacrae regni coronae. Indeed, in the past, the organic metaphor was hardly more than a symbol of unity of some sort between the 'head' and the 'members', which constructed a composite whole. ${ }^{342}$ The parts, each retaining separate individuality, were tied together by agreement or contract. The king in Hajnik's metaphoric 'body' possessed, just as the 'members' of the crown did, praerogrativa in his own right. There was no trace of Hegel's influence in Hajnik's theory which left the king's reservata intact. In contrast, in Concha's theory, under Hegel's influence, the parts of the state body were not tied together by contract. The king ceased to be an agency for itself and was degraded to be an 'element' in the personality of the State. ${ }^{343}$ In Concha's speculative body, the king was effectively deprived of his reservata. Eckhart treated 'the organic idea' of the late nineteenth century as if it had been the same idea of the organic simile used before the i88os. He could hold Hajnik rather than Concha as the author of the Holy Crown doctrine because of his failure to distinguish between the old metaphoric and the speculative Hegelian organic uses.

341 Concha 'Közjog', pp. 6 I 7-i 8 .

342 The unity was 'collective' rather than 'biological; 'medieval doctrine', wrote Gierke, 'despite all the analogies that it drew from organic life [...] regards the State as a mechanism constructed of atoms': Otto Gierke, Political Theories of the Middle Ages, ed. F. W. Maitland, I 958, p. 30. In contrast, the 'organic' idea of modern German philosophy invited us 'to walk by the uncertain and lunar right of [a] biological metaphor' - wrote Sir Ernest Barker in his introduction to Otto Gierke's Natural Law and the Theory of Society I 500 to I80o, Cambridge, i 950, p. lxii.

343 See note 339 above. 
Nagy eventually accepted Concha's innovation. Indeed the next ( I 897) edition of his work became the first textbook that expounded the doctrine in its chapter on royal power. ${ }^{344}$ Concha, appointed to the Law Faculty at Budapest in I 892, also influenced Ákos Timon, the leading constitutional historian and first holder of a new chair in Hungarian Constitutional and Legal History. ${ }^{345}$ Timon turned the doctrine into the central tenet of the history of the Hungarian constitution in a comprehensive textbook published in I902. ${ }^{346} \mathrm{He}$ read the ideas that others attributed to Werbőczy, even into earlier periods. Also, he insisted that Hungarian institutions were largely indigenous and had already existed at the time of the conquest. The doctrine of the Holy Crown became widely known after the translation of Timon's work into German, based on the second Hungarian edition, which appeared shortly before the 1905 constitutional crisis and which attained a rather mixed reception abroad. ${ }^{347}$

Belief in the doctrine sometimes produced extraordinary reactions. Politicians and highly educated university professors were totally impervious to the mildest critical observations concerning the doctrine. Hajnik's slip about the existence of totum corpus sacrae regni coronae, of which not a single instance turned up in the documents, remained an article of faith even after non-believers pointed out that the phrase could not be found before Hajnik. ${ }^{348}$ A good example of the zeal with which the doctrine could be cherished was the politics of Károly Kmety, Professor of Hungarian Public Law in Budapest from 1902 to I 929 and Independentist deputy in parliament from I 9o6. Kmety drew on Concha and Timon's ideas. From I 896 onwards, when Kmety was first appointed as a Privatdozent, these three jurists were in the same Law Faculty and influenced each other for nearly three decades. Kmety's Public Law, with a large number of editions between I 900 and the First

344 Eckhart made this point: Szentkorona, p. 323 .

345 The chair was created by Count Albin Csáky, Minister of Education, at Budapest University in I 89o. Timon was appointed to it on I February I 89 I. He held the Chair until he died in 1925. A Catholic jurist of great learning, Timon studied in Berlin and in Strasbourg in 1876 where he was a member of Laband's seminar.

346 Ákos Timon, Magyar alkotmány-és jogtörénet különös tekintettel a nyugati államok jogfejlödésére, Budapest, I902, second edn, I903, third edn, I906, fourth edn, I9 Io, fifth edn, I9 I 7 (each new edition was enlarged). A glowing review in the work appeared in Századok by Lajos Crescens Dedek, I903, pp. 63-67.

347 Idem, Ungarische Verfassungs-und Rechtsgeschichte mit Bezug auf die Rechtsentwicklung der westlichen Staaten (hereafter, Ung. Verfassungsgesch.), Berlin, I 904, second edn, I go9. Timon's work was praised abroad for the width of its well organized knowledge but the claims concerning the originality of the Hungarian political institutions were treated with polite scepticism. See reviews by Hans Schreuer in Zeitschrift für Rechtsgeschichte, 26, Germ. Abt. I 905, pp. 326-40; Paul Laband, Archiv fûr öffentliches Recht, i 9, I904, pp. 277-79; Paul Vinogradoff, The Law Quarterly Review, 2 I, I 9o5, pp. 426-3 I.

${ }^{348}$ József Barabási Kun was the first writer who pointed out that the phrase totum corpus sacrae regni coronae was never found in a Hungarian legal document: 'Széljegyzetek', p. I6; also see Eckhart, Szentkorona, p. 333 . 
World War, treated the Holy Crown as a nemzetállam, 'nationstate'. ${ }^{349}$ After the collapse of the Austro-Hungarian Monarchy in I9I8 this professor sent memo after memo to Michael Károlyi, Prime Minister, later President of the Republic, arguing that his government should recognize that it had become the trustee of the Holy Crown. When the communist Béla Kun regime took over in Budapest in March I9 I9, Kmety spoke in his lectures in support of the regime on the grounds that it 'aimed at the preservation of the country's territorial integrity'. According to an eyewitness student, he called the Revolutionary Directorate the repository of the Holy Crown to which, by virtue of the declaration of the dictatorship of the proletariat, the rights as well as the obligations of the Holy Crown had been transferred. ${ }^{350}$

The socialist lawyers denounced Kmety as a reactionary; it was asking too much of Lenin's Hungarian disciples to digest the Holy Crown doctrine. Indeed, there is some evidence that Béla Kun, the Communist leader, planned to sell St Stephen's Crown in Munich as scrap metal. ${ }^{351}$

\section{Hungarian exceptionalism}

The doctrine of the Holy Crown had a strong appeal to those in the political class who were poised to take on the ageing monarch over his right to regulate and control the army on his own. Before discussing the impact of the doctrine in general and its political utility, however, it would be instructive briefly to look at Hungarian exceptionalism which the doctrine reinforced and lent new shape to.

When the claim to exceptionalism first appeared in the late eighteenth century it had much to do with Montesquieu's influence on Hungarian politics. ${ }^{352}$ The nobles learnt from The Spirit of the Laws that, owing to the separation of powers, the Roman Republic in ancient times and England in modern times possessed a free constitution. Now, those public men who represented the ország's rather than the Court's views, argued as we have already seen, that monarchy in Hungary was

\footnotetext{
349 A magyar közjog kézikönyve, first edn, Budapest, I 900 (hereafter, Közjog). 'The nation is the total body of the Holy Crown and not one factor in it', ibid., third edn, p. 64 and n.; see also Eckhart, Szentkorona, pp. 329-3 I.

350 Pál Halász, 'A jogi gondolkodás alakulása a Magyar Tanácsköztársaságban', Fogtudományi Közlöny, I 4, I 959, p. 59.

${ }^{351}$ See István János Bálint, 'Szent István koronája kalapács alatt', Kapu, 8, I999, pp. $8 \mathrm{o}-82$.

352 Although Pál Ráday, as Ágnes R. Várkonyi pointed out, the Golden Bull had been compared to the Magna Carta even as early as I 7o6: $M T, 4$, p. 327.
} 
'mixed' rather than 'limited'. ${ }^{353}$ They furnished this claim by discovering parallels, affinity, kinship, with the 'English' constitution. ${ }^{354}$ 'No other nation apart from the English and the Hungarian can be called free' - declared County Zemplén in its I 784 address to the monarch. ${ }^{355}$ The British constitution became the standard for Hungarian parliamentarians to increase national rights at the expense of the crown's.

The earliest two propagandists of the parallels were the author of an anonymous Latin pamphlet (possibly Adalbert Barits, law professor in Pest) and György Aranka, author of a Hungarian pamphlet. Both writings appeared in I 790. ${ }^{356}$ Constitutional radicals, like Kossuth in his early years, invoked the parallels with England either to support constitutional grievances or to underline Hungary's Sonderstellung in the Habsburg Monarchy by contrasting Hungarian constitutionalism with Austrian 'absolutism'. ${ }^{357}$ Others, like the publicist János Csaplovics, produced substantial essays on the parallels. ${ }^{358}$ After I 849, Conservatives, like Pál Somssich, through excerpts from Macaulay's History of England, explored the affinities between the English and the Hungarian institutions, as a part of an attack on the 'Bach regime'. ${ }^{359}$ In the Dualist Era comparisons between the Magna Carta and the Golden Bull and insistence on other 'parallels' served the aspiration of extending Hungary's rights with respect to 'Austria'. ${ }^{360}$ But even after the dissolution of the Habsburg Monarchy philologists were looking for constitutional parallels with England in the Middle Ages. ${ }^{361}$

Yet the search for parallels could, of course, produce very little to lend support to Hungarian exceptionalism. Although the topic has not

\footnotetext{
353 See above p. 474.

354 Párhuzam, hasonlóság, rokonság. The history of this topic is yet to be written, although Eckhart regretted its lack over seventy years ago: 'Jog és alk. tört.,' p. 297. A bibliography of the subject was compiled by István Csekey after i 945, MTA, Kézírattár, Cs. I. For a short bibliography see György Bónis, 'Az angol alkotmánytörténetírás tegnap és ma', Századok, 74, I940, p. I8 I n. I. The basis of the 'kinship theory' is that in contrast to all the other constitutions which are 'written' the 'English' and the Hungarian were historical (in other words, the giraffe and the elephant have 'in common' that neither is like the hippopotamus).

355 László Péter, 'Montesquieu's Paradox on Freedom and Hungary's Constitutions I790-I990', History of Political Thought, i6, Spring ig95 (hereafter, 'Montesquieu's Paradox'), p. 84 .

356 See Győző Concha, 'Az angolos irány politikai irodalmunkban a múlt század végén' (hereafter, 'Az angolos irány'), in Hatvan év, I, pp. 2 I 3-27; Eckhart, A jog és államtud. kar tört, pp. 208-I 2. It is not certain that Barits was the author of the anonymous Latin pamphlet.

357 For an early reference from i 83 I see $K L O ̈ M, 6$, p. 2 I 7.

358 Johann v. Cisaplovics, England und Ungarn. Eine Parallele, Halle, i 842, I I 7 pp.

359 Paul von Somssich, Das legitime Recht Ungarns und seines Königs, Vienna, I 850, pp. I 30-43.

360 See Géza Jeszenszky, Az elveszett presztizs, Budapest, ig86, pp. 202-03. A substantial study on the subject was by Elemér Hantos, The Magna Carta of the English and of the Hungarian Constitution, London, I 904 .

361 Sándor Fest, Skóciai Szent Margittól a Walesi Bárdokig, ed. Lóránt Cizigány and János H. Korompay, Budapest, 2000, pp. I 2 If., I $47 \mathrm{f}$.
} 
even today entirely disappeared from public discourse, ${ }^{362}$ it has had a struggle to survive criticism and ridicule. Austrian pamphleters in the I 790 a and later German liberal authors, the Transylvanian Saxon Herald Steinacker and the Scottish traveller R. W. Seton-Watson all regarded the analogies as an idée fixe of Hungarian nationalists. ${ }^{363}$ And even in Hungary the country's best brains habitually rejected the claim to parallels as superficial. The Hungarian philosophe, József Hajnóczy, an admirer of the British constitution emphasized in his works the great differences between the two country's institutions. ${ }^{364}$ Count István Széchenyi and Baron József Eötvös referred to the parallels with derision. ${ }^{365}$ Győző Concha rejected the claim ${ }^{366}$ and Ferenc Eckhart thought it was the 'product of fantasy fed on national presumptuousness'. ${ }^{367}$

The crown seemed to provide a more promising basis for Hungarian exceptionalism than the 'parallels' with England. Kossuth, a firm believer that the Hungarians were the only truly constitutional nation on the Continent, ${ }^{368}$ never produced explanations. Others, whether under the spell of the Great Exile or not, found the explanation in the early appearance of Public Law in Hungary when countries in western Europe were still debilitated by 'feudal divisions'. This thesis became the hard core of the argument for exceptionalism for many a year. We have seen that the jurist Csemegi argued in I 862 that, while elsewhere the question was still hotly debated, in Hungary the question of sovereignty had been, centuries before, settled on the crown, a corporation of the king and the nobility. ${ }^{369}$ Hajnik, the legal historian ${ }^{370}$

362 After meeting Prime Minister Viktor Orbán on 25 April 200o, the Lord Chancellor, Lord Irvine of Lairg and the President of the Hungarian parliament exchanged facsimile copies of the Magna Carta and the Golden Bull. When Hungary is on the brink of the European Union, this old chestnut is produced to underline the country's European credentials.

363 Péter, 'Montesquieu's paradox', p. 85 nn. Apart from critics there were, particularly after I848, supporters too of the parallels abroad, particularly in Britain, e.g. Joshua Toulmin-Smith, Parallels between the Constitution and Constitutional History of England and Hungary, London, I 849 .

364 Hajnóczy József közjogi-politikai munkái, ed. Andor Cisizmadia, Budapest, I 958, see index on p. 307 .

365 For example, in the Falu jegyzôje, Eötvös in I 846.

366 Concha 'Áz angolos irány', esp. pp. 2 I $3^{-1} 4$.

367 Eckhart, 'Jog és alk. fejl.', p. 30o. Only the first edition contained the jeer which was replaced in the second edition by an inoffensive passage. Eckhart thought that instead of parallels with the British, they existed with respect to the Bohemian and the Polish institutions, pp. 296-303.

368 See, for instance, his statement, made in London in I 858, in László Péter, 'Language, the Constitution, and the Past in Hungarian Nationalism', in Ritchie Robertson and Edward Timms (eds), The Habsburg Legacy, Edinburgh, i 994, p. 2 I .

369 See p. 477 above. By contrast, the leading jurist Virozsil in the same period referred only to the similarities between the Magna Carta and the Golden Bull: Staats-Recht, I, p. 270 n. d.

${ }^{370}$ Imre Hajnik, Magyar alkotmány és jog az Árpádok alatt, Pest, I872, pp. 270-7 I. 
and István Toldy, a liberal political writer, ${ }^{371}$ both wrote in the same vein shortly after the i 867 Settlement.

Representatives of the dogmatic law school pressed the point further in the I 89os. Concha, as we have seen, while rejecting the claim to the parallels with England, argued that the special features of the Hungarian constitution could be found nowhere else. ${ }^{372}$ Ernő Nagy, with the zeal of a recent convert, added that the Hungarian institutions were 'even more constitutional' than their English counterparts. ${ }^{373}$ Timon too argued that Werbőczy's ideas were superior to English constitutional ideas. ${ }^{374}$

The scholars' assertions soon found their way to the wider public. In I892 Gusztáv Beksics, the cleverest liberal political weathervane, introduced his most popular pamphlet with two themes: (i) the Hungarian nation's legal institutions were superior even to those of the English and (ii) the jura reservata (taken over from German state theory) was a false doctrine as regards Hungary where king and nation merged into the Holy Crown entirely and where the monarch exercised only those powers that were expressly transferred to him by the nation. ${ }^{375}$ All rights were under the control of the nation. ${ }^{376}$ These themes were then variegated in speeches by politicians: 'Nowhere else in the world exists the ideal content of the (Hungarian) crown', opined an Independentist deputy. ${ }^{377}$ Apponyi referred to the Holy Crown doctrine as the 'masterpiece of the nation's constitutional genius', unparalleled in the world. ${ }^{378}$ Hungarian exceptionalism formed the hard core of the claim that Hungary possessed a 'thousand year old constitution' at the millennial celebrations in $1896 .^{379}$ Yet the seemingly unison rhetoric contained different trends.

\footnotetext{
371 István Toldy, Régi M.orsz, pp. 220-23.

372 p. 482 above. Odön Polner in his study on the legal connection between Hungary and Austria also inferred Hungarian exceptionalism from the corporate political concept of the Holy Crown: Magyarország és Ausztria közjogi viszonya, Budapest i 89 I, pp. 62f., io7.

373 Ernő Nagy, 'A magyar alkotmány állandósóga', Jogtudományi Közlöny, i 9 June i896, p. I93; idem, Közjog, I9o I, fourth edn, pp. v-vi; see also the inflated claims about the Hungarian constitution in Kmety, Közjog, I 9 I I, fifth edn, pp. vii-xxxi.

374 Timon, Ung. Verfassungsgesch., pp. 5I2-I 3; see also Albert Deák, Parlamenti kormányrendszer Magyarországon, 2 vols, Budapest, I 9 I 2 (hereafter, Parl. korm.), I, pp. 48, 65.

375 Gusztáv Baksics, A dualizmus, Budapest i 892, pp. I-2.

376 Ibid., p. 6.

377 László Rátkai, i 5 November i 902, Képv. napló, 8, p. 4 i 8.

378 Count Albert Apponyi, 9 July i 9o4, Képv. napló, 26, p. 346

379 A rather arbitrarily selected year for the anniversary of the conquest of Hungary. See János M. Bak and Anna Gara-Bak, 'The ideology of a "Millennial Constitution" in Hungary', East European Quarterly, I 5 (Sept. ig8 I), 3, pp. 307-26; Karpat, 'Die Idee' in Hellmann's Corona, pp. 349-54. Notwithstanding all the criticism that Hungarian exceptionalism has received over the years, its remnants are still around today. 'In east-central Europe Hungarian has been the only nation — said a historian to a journalist — that has possessed a thousand-year-old independent statehood': Napi Magyarország, i 9 August i 999, p. 5 .
} 


\section{The impact of the doctrine}

Political rhetoric is never uniform. Only a part of the political class and literati accepted and used the new vocabulary of the doctrine which made headway in the i 890 . In the legal profession most of the Publicists and legal historians swallowed it hook, line and sinker, while the Civilians, the civil servants and conservative academic historians were seemingly reluctant. In parliament, the growing number of Independentists and Apponyi supporters, who stood poised to take away from the monarch his army rights, grasped the doctrine with both hands. Predictably, the Liberal establishment and the government remained lukewarm. The Budapest (progressive, Jewish) professional and business classes were rather flabbergasted.

The crown tradition, visible and invisible, formed a prominent part in the pomp and ceremony with which the millenary of the conquest, the honfoglalás, was commemorated in $1896 .{ }^{380}$ Yet the new doctrine was missing from the speeches of the 67'er Liberals in office; likewise, after the turn of the century when the Opposition in the House began to demand the introduction of Hungarian as the language of command and service in the Hungarian regiments of the common army. The incomprehension between the traditional rhetoric, in which crown and nation were juxtaposed, and the new rhetoric engendered by the doctrine, which insisted that the king, through the crown, merged in the nation, led to a head-on clash between the government and the Opposition. ${ }^{381}$

Supporters of the doctrine urged people not to use the word 'crown' for the monarch. ${ }^{382}$ The dictum that 'it is not the monarch who inherits the crown but the crown that inherits the monarch', ${ }^{383}$ when crown and nation became synonymous, showed the utility of the doctrine for those who were set to deprive the monarch of his army rights. It was not a coincidence that it was Apponyi who, in the Great Defence Debate of I 889, had transferred in his speech the presumptio juris of the monarch's army reservata to parliament, turned out to be 'the most

\footnotetext{
380 See note above.

381 'Orthodox' liberals even after the turn of the century juxtaposed 'nation' and 'crown' this being the language of Deák who held that the I 867 Settlement was a contract between two actors in which they mutually recognized each other's rights. When, however, the head of the new government Count István Tisza warned in his policy speech on 6 November I 903 about the consequences of any conflict over the language of the army, and urged harmony between the 'nation' and the 'crown', József Madarász, Independentist old hand, interjected: 'The crown is ours! The country's'. 'Therefore the language ought to be Hungarian' - added another Independentist: Képv. napló, 28, pp. 280-8I. See also the encounter with minister Fejérváry in the House p. 47 I above.

382 Gejza Ferdinándy argued that the usage was in conflict with the principles of the constitution and the independence of Hungary and that either the usage or the doctrine of the Holy Crown had to be abandoned: Korona és monarchia, Budapest, i 903, p. I I .

383 István Cisekey, A magyar trónöröklési jog, Budapest, i 9 I 7, p. I 4.
} 
effective propagator' of the doctrine ${ }^{384}$ at home and also abroad. ${ }^{385}$ And his growing influence in politics between 1903 and I 905 led to the attempt by parliament to tilt the constitutional balance against the crown.

The issue was now the changeover to parliamentary government, replacing the balanced constitution which Deák had secured back in the I 867 constitutional Settlement. Apponyi became the leading force in the Coalition that plunged the country into the constitutional crisis in I905. The doctrine turned up in speeches that justified 'national resistance' against the 'unconstitutional' Fejérváry government. ${ }^{386}$ After Franz Joseph had emerged from the crisis with his prerogative left intact and Sándor Wekerle's Coalition government was appointed in April 1906, the doctrine acquired semi-official status, for the Coalition, although defeated, did not abandon its aspiration to have a separate Hungarian army. Apponyi, now as a minister of the crown, sponsored publications in which he set out the doctrine at length. ${ }^{387}$ Yet the doctrine failed to become Hungarian official ideology in the life-time of the Monarchy. The Wekerle government turned out to be short-lived; Franz Joseph allowed it to disintegrate in igog. Tisza's reorganized 67'ers were back in office and the doctrine of the Holy Crown was put on the back-burner. It was a pointer to the reservations with which the Khuen-Héderváry government treated the doctrine that when a new Chair was established in Public Law at the Law Faculty in Budapest in I 9 I I, the Faculty (in which Concha, Timon and Kmety were all professors) invited Count Apponyi and submitted the proposal to minister Count János Zichy. The government, however, 'refused to make the appointment on political grounds' and the chair was eventually filled by Ernő Nagy ${ }^{388}$ — a scholar not interested in the political implications of the doctrine.

${ }^{384}$ Gyula Szekfû, Három nemzedék és ami utána következik, third edn, Budapest, I935, pp. $399-400$.

385 Count Albert Apponyi, 'Le parlement de le Hongrie', in Annuaire du Parlement, 4e année i 90 I, Paris, I 902, ch. Io, pp. 864-958, esp. pp. 880-82; idem, A Brief Sketch of the Hungarian Constitution, Budapest, I 908, esp. pp. I6- I 8; 'The Hungarian Constitution', in Hungary Today, ed. Percy Alden, London, I 909, pp. I03-208, esp. I $23^{-25}$ (the three publications are essentially identical).

${ }^{386}$ See, for instance, the speech by Baron Dezső Prónay at the meeting of the 'leading county', Pest, on 20 June i 905 , József Horváth, Az I905/6. évi vármegyei ellenállás története, Budapest [I907], p. 299; on the constitutional crisis see Péter, 'Verfassungsentwicklung', pp. $45 \mathrm{I}-6 \mathrm{I}$

387 See note 385 above. The teaching of Concha, Timon and Kmety was also accepted by the Coalition's foreign supporters. See, for instance, C. M. Knatchbull-Hugessen's The Political Evolution of the Hungarian Nation, 2 vols, London, I 9o8, see esp. I, pp. 39, 90-9 I, etc. Its robust pro-Coalition political bias was pointed out by a critical review in The Saturday Review, i 6 January i 9o9, p. 8 I.

388 Eckhart, A jogi kar tört., pp. 62 I-22. 
Paradoxically, the doctrine of the Holy Crown acquired a dominant position in public life only after the collapse of the Monarchy. Once the old political order was restored following the revolutionary period, without the monarchy, in I920, the doctrine was elevated as the official ideology of the regime. As we have seen, the Law of I 930 ordained that the judges should pass sentences 'in the name of the Hungarian Holy Crown'. ${ }^{389}$ After the dissolution of the Austro-Hungarian Monarchy neither state independence nor the reserved rights of the monarch were any longer relevant contentious issues. The kingdom was formally restored in I920. But as the Western Powers did not allow the king to return, the legitimacy of the regency was bolstered by the elevation of the doctrine to official ideology. An obvious reason for the prominence accorded to the doctrine was that within the new political élite the former Independentists rather than the 67'ers possessed the upper hand. But the chief reason for the doctrine's elevation must have been the territorial question. Hungary did not accept as final the Trianon Treaty of I920, which disposed of more than two-thirds of Hungary's former territory. The justification for the 'revisionist' policies pursued by successive Hungarian governments after I 920 became the dominant context in which the Holy Crown appeared. When between I 938 and I940 parts of the lost territories were reattached to Hungary, according to the enacting laws, these parts 'returned to the body of the Hungarian Holy Crown'. ${ }^{390}$ The triumphalist flourish by the writer Ferenc Donászy in I 94 I invoking the magic of St Stephen's Crown (once more mixing up the visible and the invisible) stands for many others dating from the period. ${ }^{391}$

It became the ironic fate of the doctrine that just about the time when it was at last elevated to the level of official ideology, it suffered a devastating blow from the pen of the leading legal historian which undermined its credibility. Before turning to that subject, however, we have to examine the political efficacy of the doctrine.

\section{The utility of the doctrine}

The Holy Crown doctrine undoubtedly possessed utility. The mystery of the whereabouts of sovereignty in the Habsburg Monarchy was not

\footnotetext{
389 See p. 457 and note i 86 above.

390 See p. $46 \mathrm{I}$ and note 204 above.

391 'The magical unity [. . . ] of the Holy Crown's body brings together the empire of St Stephen from the green leaves of the Carpathian slopes down to the blue Adriatic. The idea and the binding force of the Holy Crown proved stronger than the rule of the Ottoman crescent lasting one and a half centuries; it proved stronger than the suffocating clutches of the German imperial eagle and stronger than the chains forged in Trianon. By now all these are far gone while the Crown of St Stephen shines with the light of nine hundred years. And we believe, we believe with inextinguishable faith that St Stephen's empire will be reunited in the Danube basin.' Quoted by Bertényi, Szent Korona, p. I 64.
} 
merely an intellectual puzzle. The assimilation of the German dogmatic school's vocabulary into Hungarian constitutional discourse and the concept of the personality of the State, in particular, highlighted longstanding problems of constitutional balance. Power was still tilted too heavily in favour of the monarch. As king, the executive power was formally vested in Franz Joseph, although he exercised it through a ministry that was responsible to him as well as parliament. In legislation, the monarch was equal partner with parliament. ${ }^{392}$ Over and above these rights, the monarch possessed powers that were entirely outside the control of the Hungarian parliament. Franz Joseph, as emperor, was the monarch of the Lands represented in the Reichsrat - the stronger partner in the Dualist relationship. Above all, he had near complete personal control over the Monarchy's common institutions, including the army buttressed by long-standing legal presumption. The Holy Crown doctrine, by reversing the legal presumption that hitherto buttressed the king's reservata, undermined (potentially) the security of the prerogative. It subordinated the common monarch's rights to the legislation of the crown's total corpus within which the monarch was said to be a mere 'organ'. ${ }^{393}$

Although the doctrine did not resolve the juristic problem of the whereabouts of sovereignty, an intractable one for Austria-Hungary, ${ }^{394}$ its creation was, by any standard save historical veracity, a considerable political achievement on the part of the Law Faculty of Budapest University. The refashioning of Hungarian constitutional history, as we have seen, bolstered the claim to a thousand-years'-old constitutional life. Also, it reduced the much-lamented dependence on German scholarship and asserted the legal sovereignty of Hungary without making ineffective the constitutional dualism of crown and nation. Although the doctrine itself was not politically radical, forged at a time when crown and parliament were gingerly moving towards major confrontation, it undoubtedly helped the latter side. Its effectiveness, however, should not be overrated. Strictly speaking, parliamentary government did not necessarily follow from the doctrine. We can distinguish at least three different positions taken up by those who professed to adhere to the doctrine:

\footnotetext{
392 To describe the king's participation in legislation as 'veto power' is a common enough mistake of scholars. See Péter, 'Verfassungsentwicklung', pp. 4I 2 - I 4.

${ }^{393}$ See above (Concha), pp. 483-84. On the lower level of a well-known Independentist ringleader, this point was understood as: 'The claim that the army belongs to the nation rather than the king means the strongest loyalty, because, according to the splendid imprescriptible theory of the Holy Crown, all nobles used to be its members in the past, just as all Hungarian citizens are today. But his Majesty the king is also a member.' Géza Polónyi in the debate on the new government orders on the coat of arms and flags, I December igi 5 , Képv. napló, 27, p. 288.

394 As, for instance, James Bryce argued in his Studies in History and Jurisprudence, Oxford, I90 I, 2, pp. 9I-92.
} 
I. For Count Albert Apponyi it followed from the doctrine that government in Hungary was parliamentary, at least in the sense that ultimate control over policy was already vested in parliament. Because of this belief he left the Liberal party in I 903, joined the Independentists in the following year and became the drafter of the Address in April I 905 during the constitutional crisis in which the House demanded that the crown should appoint a government 'such as would have the House's confidence'. ${ }^{395}$ The Coalition claimed that Law III of I 848 had already established parliamentary government in Hungary. Among the leading jurists Károly Kmety, himself an Independentist deputy, likewise represented the radical interpretation of the doctrine. Yet it would be premature to rush to the conclusion that we have the key in hand to understanding the politics of the doctrine.

2. Quite unexpectedly, the maker of the doctrine, Győző Concha (unlike Apponyi) failed to whistle in the dark. He understood that Hungary did not (and could not as yet) have parliamentary government. The Politics professor attacked in an article the Coalition's claims: the I 848 Laws did not establish parliamentary government, for that system was, wherever it existed, an informal convention rather than a legal institution and in Hungary the convention had not yet evolved. ${ }^{396}$ Concha also developed doubts about the efficacy of the doctrine in practical politics. ${ }^{397}$ Albert Deák, author of the first monographic study on the Hungarian political system and a firm believer in the doctrine (even after the fiasco of the I905-I9o6 constitutional crisis), was more optimistic than Concha: it was the mission of the Holy Crown principle that the nation should acquire 'the dominant weight' in the working of the State. ${ }^{398}$

3. The problem with the doctrine was (apart from being quite unrealistic about the balance of effective power in the AustroHungarian Monarchy) that, as it did not abandon the duopoly of king and nation, the monarch could use it as much as parliament. In the royal Rescript, which reappointed the Fejérváry cabinet in October i 905, Francis Joseph (emphatically and for the first time) styled himself

\footnotetext{
395 Péter, 'Verfassungsentwicklung', pp. 453-54.

396 László Péter, 'The Aristocracy, the Gentry and Their Parliamentary Tradition in Nineteenth-Century Hungary', SEER, 7o, i 992, I, pp. 77-i i o (pp. I 07-08).

397 Concha understood that the function of the doctrine was the replacement of structural dualism by a body politic in which the political will was unified. In an article he condemned parliamentary fillibustering in I 904. Later, in I92 I, he wrote with some resignation that the Sacrae Coronae Corpus did not function properly as the concept of the legal State because the head and the members, as in the Middle Ages, were connected by contracts rather than laws, Hatvan év, 2, pp. I 83, 570-7 I.

398 Deák, Parl. korm., I, p. I 88.
} 
as 'the wearer of the Holy Crown'. ${ }^{399}$ Further, Bertalan Lányi, Minister of Justice in the Fejérváry cabinet, in setting the record straight after the crisis, abundantly used Timon and Kmety's work. But he inferred from the doctrine the dominance of royal power and rejected the claim that Hungary had a parliamentary system of government. ${ }^{400}$

All in all, the effectiveness of the doctrine was more limited than is frequently assumed. The appeal of ideologies, however, does not ultimately depend on their utility in its narrow sense but on other factors.

\section{Against the current: Eckhart}

While the traditions and innovations of the visible crown (at least until recent years) have hardly ever caused dissent, ${ }^{401}$ innovations about the invisible crown frequently did so. The doctrine of the Holy Crown, despite its enthusiastic reception by the Independentist wing of the political class, with the charismatic Count Apponyi as its most ardent promoter, remained a contested product of the dogmatic law school.

At the turn of the nineteenth century, cultural life, outside the parliamentary oligarchy of the aristocracy and the gentry, was largely urban, progressive and dependent on support from the Jewish business classes. Predictably, the Holy Crown doctrine had no appeal to this bourgeois counter-élite whose journalists gave short shrift to it. ${ }^{402}$ It was as much as one would have expected. Surprisingly, however, the 67 'er Liberal establishment (by no means being all king's men) were also resistant to the reception of the doctrine. Most of them kept their heads down but a few spoke up. Jenő Balogh, a Criminalist at the Budapest Law Faculty, attacked Timon for his claim that the development of the Hungarian legal system was largely indigenous and superior to other European legal systems. Balogh deplored 'the patriotic

\footnotetext{
399 I 6 October, József Kristóffy, Magyarország kálváriája, Budapest, i 927, pp. 26o-6 I. That most astute political observer in Vienna reported to PHS London that 'the passage in which the Monarch styles himself not King or ruler, but "wearer of the sacred crown" of St Stephen, is particularly significant, since, according to Hungarian constitutional theory, kingship resides in the holy crown itself, and not legally in the person who may inherit the right to wear it unless and until that person has been duly crowned with it according to the traditional Hungarian ritual and after giving the traditional and clearly defined pledges concerning the inviolability of the Constitution. The phrasing of the rescript thus contains a definite reminder to the Hungarian people that the King is in possession of full constitutional rights, of which he is minded to make use, just as he is determined not to suffer any encroachment upon the independence and sovereignty of the Hungarian nation'. H. W. Steed, The Times, ig October ig05.

400 Bertalan Lányi, A Fejérváry-kormány, Budapest, I 9og, esp. pp. 204-22.

401 Joseph II's measures might have been the sole exception, see above pp. i6- I 7 .

402 A typical example is the pamphlet of Oszkár Gellért, A szent korona tan hazugságai (The lies of the doctrine of the Holy Crown), Budapest, I 908 in which the author rejects the doctrine as sham-constitutionalism.
} 
clamour' which surrounded the reception of Timon's book. ${ }^{403}$ The Romanist and Givilian Gusztáv Szászy-Schwarz ridiculed the whole literature on the Holy Crown doctrine and treated it as trash. ${ }^{404}$ Whereas these strictures were largely ignored by the adherents of the doctrine, Henrik Marczali's 'Hungarian Constitutional Law' published in Paul Laband's series in German ${ }^{405}$ led to a public scandal and Hungary's leading historian ${ }^{406}$ was ostracized. Marczali distinguished the uses of the 'crown' (signifying the State) from those of the 'Holy Crown' (which referred to the Lehensgewalt, the royal land-donation only). ${ }^{407}$ This accurate reading of Werbőczy, together with much else of Marczali's views, inspired a long-winded and vicious attack by Ödön Polner, a leading Publicist, who dismissed the book as a dilettante work. ${ }^{408}$ The attack marked the beginning of Marczali's isolation.

These objections were expressions of dissent rather than critical analysis of the new literature and they appeared in the last years of the Monarchy. There were no dissenting incidents in the i920s, a decade during which the doctrine, for the first and the last time, enjoyed a monopoly position in government and academia. ${ }^{409}$ After 1920, with the (alien) royal power in abeyance, the doctrine lost its raison d'être (Deák's usage 'the Lands of St Stephen's Crown' adequately supported territorial revisionism). Yet it came as a bolt from the blue when, in I93 I, a reputable conservative law professor examined and repudiated the doctrine and much of the new legal-historical literature on grounds of scholarship. From now on historians had an 'open season' on Timon's theories.

Ferenc Eckhart was appointed to the chair of Constitutional and Legal history at the Law Faculty in Budapest in I929. His fifty-page essay on Hungarian legal scholarship, which appeared in a volume on

403 Jenő Balogh, 'A jogtörténet tanítása hazánkban’, Budapesti Szemle, i 22, I 905, pp. I 6 I -97 (pp. I67, I 79)

404 Gusztáv Szászy-Schwarz, Parerga, Budapest, I 9 i 2, pp. 448-55.

405 Marczali, Ung. Verfassung, and see notes I 58 and 220 above.

406 G. P. Gooch wrote: 'Not till the emergence of Marczali did Hungarian historiography break the shackles of a narrow patriotism. His [works] represent the highest achievement of Magyar scholarship'. History and Historians in the Nineteenth Century, London, I952, p. 400.

407 Marczali, Ung. Verfassung, pp. 25-29.

408 Ödön Polner, 'Magyar közjog német nyelven', Fogállam, i I, I g I I, pp. 337-62 and 4 I 7-43. What particularly upset Polner was that Marczali, by denying the legal unity of rex and regnum and emphasizing their legal dualism, let the cat out of the bag. See p. 345 .

409 Although on specific points historians sometimes criticized Timon's doctrine, e.g. R. István Kiss on aviticity, 'Nagy Lajos és az ősiség', in Emlékkönyo gr. Klebelsberg Kunó negyedszázados kulturpolitikai müködésének emlékére, Budapest, I925, pp. 24I-48 (p. 248). See also Timon, Ung. Verfassungsgesch. pp. 555-56. Gyula Szekfû also criticized Timon's work although not his view of the Holy Crown doctrine but Timon's insistance in reading Werbőczy's ideas into the early Middle Ages: A magyar állam életrajza, 2nd edn, Budapest, I 923, pp. 227-28. Szekfû, like the rest of historians was a firm believer in the doctrine: ibid., pp. 69-70. 
new historical methods ${ }^{410}$ edited by Bálint Hóman, a leading medievalist, created a mighty row. This reached even parliament where Eckhart was reprimanded by the Minister of Justice because of his injudicious treatment of views that were in the 'sanctuary' of national feeling. The Minister of Education, pressed by the Hungarian Academy, had to come to the rescue of the professor by making a conciliatory statement. The publication of the essay, as Eckhart bitterly remembered years later, nearly cost him his chair. ${ }^{411} \mathrm{He}$ went on working on the subject, however, and ten years later was able to publish his comprehensive monograph on 'the History of the Holy Crown idea' which, sixty years later, is still the only proper historical analysis available on the subject. The book silenced his opponents for a few years. ${ }^{412}$

Eckhart argued in I93 I that because the Habsburg Monarchy had ceased to exist, an impartial examination of constitutional questions could no longer be labelled as unpatriotic. It was now time to look at the historical claims the jurists and legal historians had made before I 9 I $8 .{ }^{413}$ Each period of the constitution should be discussed in its own terms rather than 'bringing concepts into the past that are quite alien to it'. ${ }^{414}$ Laband's Hungarian disciples regularly erred in this respect: they treated the medieval legal material in terms of modern concepts like 'sovereignty' and the 'personality of the State'. ${ }^{415}$ They lived in a magyar glóbusz claiming exceptionalism for Hungarian legal developments. The jurists postulated the principle of a thousand-year-old constitution as a continuously existing system of unified public law which Hungary possessed before any other nation in the West. This was hardly more than 'muscle-flexing chauvinism' on the part of the dogmatic School. ${ }^{416}$ It was particularly painful for many of Eckhart's readers that he insisted on Czech and Hungarian constitutional developments being analogous. ${ }^{417}$ Eckhart set out a programme and a conceptual frame within which the growth of Hungarian political

\footnotetext{
410 Eckhart, 'Jog és alk. tört.' (see notes 50 and also 9o above), pp. 269-320.

411 Ferenc Eckhart, Magyar alkotmány-és jogtörténet, Budapest, I 946, p. 3. In parliament the Minister of Justice, Tibor Zsitvay, censured Eckhart's essay but the Minister of Religion and Education, Count Kunó Klebelsberg, defended the principle of free speech. On the 'Eckhart debate' see Elemér Mályusz, 'Az Eckhart vita', Századok, 65, I 93 I, pp. 4o6-ig (still the best); József Kardos, 'Az Eckhart-vita és a szentkorona-tan', Századok, io3, ig69, pp. I I 04-I 7 (pedantic); Bertényi, Szent Korona, pp. I6 I-64 (informative).

412 Eckhart, Szentkorona, see note 6 I above; for its German summary see Karpat 'Die Idee', see note go above.

${ }^{413}$ Eckhart in I93 I was the pathfinder but other scholars soon set out on the same route. Emma Bartoniek, Péter Váczy, József Deér and György Bónis all looked at the subject from a new perspective.

414 Eckhart, 'Jog és alk. tört.', pp. 28 I -82.

415 Ibid., p. 282.

416 Ibid., pp. 304-06. The last phrase and a few other offensive phrases were deleted from the second edition ( I 93 I) of the volume. The changes did not effect the argument.

417 Ibid., pp. 3oof.
} 
institutions should be explored. He concluded on the point that, as elsewhere, in Hungary the monarch and the subjects were connected through contracts in the Middle Ages and later (for instance, the royal Oath, the capitulationes and the decreta), because 'the unified system of public law, the characteristic of the modern state was missing' ${ }^{418}$ The jurists and many politicians on the right were dismayed and alarmed. An articulate but noisome attack on Eckhart's views, written by Kálmán Molnár, professor in Pécs, added little to the subject despite its outlandish argument. Scholars should be able to 'rise above' the contradictory historical data in order to 'abstract their spirit'. The 'distillation of their substance through jurisprudence' was the doctrine of the Holy Crown. ${ }^{419}$ In parliament a member lamented the fact that 'a fine illusion was once again torn out of the soul of Hungary's youth'. ${ }^{420}$

When, ten years later, Eckhart carried out his programme and published his study on the history of the Holy Crown, long overdue basic information was at last furnished on the subject. ${ }^{421}$ Eckhart set hundreds of corona passages in their institutional context and interpreted the rich variety of ideas which the term represented at one time or another. In fact, notwithstanding the title of the book, Eckhart did not look for a 'concept' with a set of definable properties to which the crown uses could be adduced. He describes how the term took on new meanings, frequently without losing old ones. In other words he takes it for granted that the term, like most other political terms, is multivocal. Another notable feature of his work is that it is nearly as much about regnum and ország uses as it is about corona. For this reason, Eckhart's analysis sheds light on the fundamental structural feature of Hungarian political institutions: the complementarity of monarchic and ország powers. Yet he abandoned a position in I 94 I which he had held before. We have seen that Eckhart in I93 I treated corona and regnum as two distinct loci of authority because, before the nineteenth century, 'a unified system of public law' did not exist. ${ }^{422}$ Statements in similar vein may be found throughout Eckhart's works before i 94 I. He wrote in I 928 that 'the State concept as a legal person' appeared in Hungary (as

418 Ibid., p. 320.

419 Kálmán Molnár, Alkotmánytörténeti illuzió-e a magyar alkotmányfejlödés jellegzetes közjogi iránya?, Pécs, I93I, pp. 29 and 54; see also Móric Tomcsányi, 'A magyar közjog és jogtörténet téves szemlélete', Magyar Jogi Szemle, i 93 I, pp. 27 I-94; Miklós Nagy, 'A szent korona eszméje', in Serédi, Emlékkönyv, 2, pp. 269-307, and esp. pp. 305-o6. On Eckhart's side though not in complete agreement with him on every point, see László Erdélyi, $A z$ ezeréves magyar alkotmány, Szeged, I93 I, esp. pp. 20-26.

420 Sándor Kálnoki Bedő in parliament, Budapesti Hirlap, 8 March i 93 I, quoted by Kardos, 'Az Eckhart-vita', p. i I 2.

421 Eckhart, Szentkorona, pp. 3-4.

422 Eckhart, 'Jog és alk. tört.', p. 320 and earlier: 'the concept of the personality of the State did not exist in the Middle Ages', p. 282. 
elsewhere) in the eighteenth century. ${ }^{423}$ During the debate in I93 I he argued that the king and regnum had stood in respect of each other as two distinct legal persons. ${ }^{424}$ In 1933 he wrote, in relation to the Bocskai uprising, that 'the concept of state unity between the king and the estates was missing'; the two sides were independent. ${ }^{425}$ In contrast, by I94I, Eckhart has changed his position in his book. He fell in line with communis opinio and held that the 'concept of the State' had appeared in Hungary already in the Middle Ages. ${ }^{426}$

This could be one of the reasons why Eckhart's work enjoyed a good reception: praise and accolade were showered on the author by the reviewers without a dissenting voice. Most of the reviews were concerned with the medieval periods and, by I94I, no established scholar was inclined to defend Timon's school. But Eckhart's book never received, at least in Hungary, the close attention and critical comment it would have undoubtedly deserved. This was particularly so for the modern periods. As far as I know the only review that took the argument further was by the medievalist József Deér in the Századok. He also pointed out that Eckhart's use of the term 'state' was inconsistent. ${ }^{427}$ Szekfü wrote a splendid, informative article for the Magyar Nemzet. ${ }^{428}$ The historians, argued Szekfü, had never touched even with a barge-pole the theories with which the jurists ${ }^{429}$ embellished Werbőczy. At last, however, with Eckhart's work, so Szekfü explained, we have evidence of the 'thousand years old Holy Crown idea', the product of our 'national genius'. ${ }^{430}$ This was devastation; Szekfü, unwittingly, emasculated Eckhart's seminal study by inferring something into it which it was Eckhart's avowed purpose to reject. At any rate, within a few years the ancien régime was swept away by the Red Army and historians in the new regime turned their back on subjects like corona and regnum.

Marxist historians in the I95os were primarily concerned with economic change and social progress rather than ideology - except when they denounced bourgeois historians for their reactionary views.

\footnotetext{
${ }^{423}$ Eckhart, A volt monarchia, pp. 5-6. The concept of the state in the Hebsburg Monarchy appeared under Maria Theresa.

${ }^{424}$ Eckhart, Alkotmányfejl., pp. I $5-$ I 6 ; he also surmises, however, that these 'dualistic features' might have induced Werbőczy to 'formulate the Holy Crown doctrine' in order to influence the attitudes of the king and the ország.

${ }^{425}$ Ferenc Eckhart, 'Bocskay és híveinek közjogi felfogása', in Károlyi Árpád emlékkönyv, Budapest, I 933, pp. I 33-4I (p. I 34).

${ }^{426}$ In the late fourteenth century, see note i I I above.

427 Deér, 'A szentkorona', see notes iog and I I I.

428 3o March 194I, republished in Gyula Szekfú, Állam és nemzet, Budapest, I942, pp. 304-I I.

${ }_{429}$ Szekfü even lists their names: 'Timon, Kmety, Concha and Ernő Nagy', ibid., p. 305.

${ }^{430}$ Ibid., p. 3 I I.
} 
This was the context in which the 'crown', without any adjective, ${ }^{431}$ occasionally turned up in historians' conferences and writings. The task of political rhetoric was the debunking of religion and nationalism. And now Eckhart became the Prügelknabe for the 'bourgeois' sins of the Holy Crown doctrine. Márton Sarlós, Communist old hand elevated to a chair in the Law Faculty in Budapest, launched in I 954 a venomous attack mitigated only by pomposity: Eckhart was denounced as antiMarxist, indeed he was worse than even his predecessors. ${ }^{432} \mathrm{He}$ was a racist, stirred up revisionist propaganda, and served 'Horthy Fascism'. ${ }^{433}$ Sarlós also rejected Eckhart's method for it was primarily concerned with words, i.e., trivia. ${ }^{434} \mathrm{He}$ never stopped denouncing Eckhart and the Holy Crown theory as anti-Marxist etc. and, after Eckhart's death he went on denouncing Eckhart's student, György Bónis. ${ }^{435}$ Comrade Sarlós did not have followers and by the ig6os the Kádár regime had eased up on the class enemy and become less intolerant towards non-Marxist views and methods in history, at least for the periods before I 9I 7. Ideological purity was not needed as long as the Socialist system was able to satisfy the expectations for better living conditions.

\section{Revival}

The oil crisis in the I97os and much else beside shattered the regime's optimistic expectations about the effectiveness of its economic reforms. It was then that the regime rediscovered the efficacy of the national idea as a way of gaining political support. One of the moves through which the regime was willing to meet Hungarian national feeling halfway involved the crown tradition. The regime now put out feelers to Washington as to whether the government of the United States would be prepared to return St Stephen's Crown; after some footwork the Americans were. The Hungarian government promised that the

\footnotetext{
431 The Communist authorities even in the r 970 os were peevish on this point, see Bertényi, Szent Korona, p. 5 .

${ }^{432}$ Eckhart 'did not only accept the doctrine of the Holy Crown in its entirety, in fact in religious mythology and the ultra nationalist chauvinism he went even further than Timon', Márton Sarlós, 'A szellemtörténeti irány és a magyar jogtörténetírás', Jogtudományi Közlöny, I I, I 956, pp. 87- iо3 (p. 88).

433 Márton Sarlós, 'Az organikus és a szentkorona-államelmélet a magyar történetírásban', Magyar Tudomány, i 96o/3, pp. I I I-22 (p. I I I).

434 'This method which interprets charters is only interested in words (like corpus, membrum) and deduces the general principle of organic state theory', instead of examining the class structure. 'I must confess I cannot appreciate the historical method that having found little florid passages in documents, façon la parler, will construct a great edifice following his whim'. Márton Sarlós, 'A 'Szent Korona Tan” kialakulásához', Jogtudományi Közlöny, July-August i 959, pp. 357-62 (pp. 359, 360).

${ }^{435}$ Márton Sarlós, 'A feudális parazitizmus a kiegyezés utáni jogszabályainkban és a magyar jogtörténetírásban' in Fogtörténeti tanulmányok, 2, ed. Andor Cisizmadia, Budapest, I968, pp. $273^{-85}$ (pp. 276-77).
} 
crown would be put permanently on public display. The ceremony of the crown's handover in parliament in January I 978 was a rather quiet affair. ${ }^{436}$ The crown and the other regalia were exhibited afterwards in a glass case in the National Museum and people began to flock to see them. Through the public display of the 'Hungarian crown' (as it was generally referred to at the time), the regime claimed that it was not insensitive to the national traditions of the past. Also, the regime was to demonstrate its international acceptance. Otherwise the crown was not to be exploited for political purposes. Nor was there any demand to do otherwise outside the party. The crown was a national relic, a treasure that belonged to the past, as such its place was in the National Museum. The historian Iván Bertényi may have expressed a general attitude in I 978 .

The idea of the holy crown has ceased to be an effective political ideology. Today only legal and other historians are concerned with it. ${ }^{437}$

Activists on the political right (outside the circle of scholars), however, began well before I989 to take an interest in St Stephen's Crown, together with the Holy 'Dexter', as hallowed relics of Hungarian national identity. As much could be predicted, but the revival of the tradition of St Stephen's Crown had a more specific context in the I980s: it served as a catalyst of political change, or so it is claimed. Géza Jeszenszky recalled twenty years after the event that the American gesture to return the crown

was intended towards the Hungarian people rather than towards the government. The handing back of the crown was tied to agreed conditions and guarantees. This was why hundreds of thousands soon came to admire the Holy Crown and the other regalia exhibited in the National Museum. And this set in train an unpredictable transformation in Hungarian society. The ancient relic without which (as Cardinal Gentile, papal nuncio, had reported in the fourteenth century) power was not legitimate, performed a real miracle. Hungarians, falling to their knees in front of it, chastened from the effects of Communist brainwashing, shed the complexes of national inferiority and shame and the disparagement of national inheritance and traditions. The Holy Crown gave them the strength and courage to censure

436 The Hungarian regalia, including St Stephen's Crown, were brought to Budapest from the United States by a delegation headed by Cyrus Vance, Secretary of State, and handed over to the President of Parliament on 6 January i 978. The agreement between the two states stipulated that the crown should be exhibited for the public in an appropriate place: Katona, Stephanskrone, p. 566. The visible crown in Hungary had, of course, been in the past quite invisible and used only for coronations. Its visibility is once more restricted today, writes Radnóti, 'Üvegalmárium', p. 55.

437 Iván Bertényi, A magyar korona története, Budapest, I978 (in fact the first edition of author's Szent Korona), p. I 49 . 
the regime more openly. Hungarians raised their heads and began to think for themselves. ${ }^{438}$

After the collapse of the Communist regime Holy Crown societies with their own publications were formed by conservative groups. For them the crown, the visible and the invisible Holy Crown, was not a respectable relic of national identity, something to be tucked away in a museum. Rather, it was an integral part of the present, a living tradition and a part of national identity in this sense. ${ }^{439}$ It has even been argued either that the doctrine of the Holy Crown was still valid constitutional law or that parliament ought to recognize it as such. ${ }^{440}$ We can only surmise what may have motivated these groups. Preoccupation with the past has always been a Hungarian pastime. But nostalgia apart, the indigestible culture-shock of Trianon ${ }^{441}$ the desire to re-establish closer links with Hungarians living beyond the borders and sometimes even flirtation (in a coded language rather than overtly) with the idea of border revision have been obvious factors. There is not much evidence that either the new political class or the public has taken these groups seriously. Their position and political support has been marginal. ${ }^{442}$

Nevertheless, since I989, the Holy Crown tradition has been reincorporated with the country's political discourse. ${ }^{443}$ After heated arguments parliament decided in July I990 to cap the Hungarian

438 Géza Jeszenszky, historian and Hungary's foreign minister between I990 and I994, referred to the 1998 statement by American ambassador Peter Tufo that the gesture in 1978 had indeed been towards the people and not the government: 'A gesztus a magyar népnek szólt', Magyar Nemzet, io January i998, p. 4. The regime also contributed to the revival of the Holy Crown tradition in the I g8os when the festivities, including fireworks on 20 August, St Stephen's Day, and their media coverage became official policy. On the Holy Dexter: see note 5 I above.

439 The earliest association was probably the Magyar Szent Korona Társaság (Feb. I 989); the Szent Korona Nemzetszövetség and others were established in the I $990 s$.

440 István Kocsis, a Transylvanian writer who has moved to Hungary, in his A Szent Korona tana, Budapest, I 995, second edn, I 996 (hereafter, Kocsis, Szent Korona) reviewed the books that have taken this position, pp. 270-72. See also the politician Zsolt Zétényi's $A$ Szentkorona-eszme mai értelme, Budapest, I997, and Magyarország Szent Koronája, Budapest [2000].

${ }_{441} \mathrm{Had}$ the doctrine of the Holy Crown been adhered to in I9I8, the 'Trianon dictate' might have been avoided — surmised István Kocsis, Demokrata, ig96, i 9, p. 39. 'A Szent korona Nemzetszövetség magyar külpolitikai koncepciója', Hunnia, September I997, pp. I 8-20, a vaguely revisionist programme.

442 Because of the requirement of 'the two-thirds support' for constitutional change, even minor amendments can only be put through with great difficulties in Hungary.

${ }^{443}$ For a summary of the changes of the symbolic elements in Hungarian politics since I 989, see Daniel Fehér, Panem et Circenses (MA Dissertation, SSEES, University College London, 2000), esp. pp. 25-39. 
national escutcheon with St Stephen's Crown ${ }^{444}$ Changes in linguistic usage reflect gradually changing attitudes. The magyar korona before I 989 first became szent korona and subsequently Szent Korona in general usage. ${ }^{445}$

There never was a traffic jam by historians on the road to Damascus (to borrow a phrase from Péter Esterházy) on attitudes toward the Holy Crown. But transition there has been. József Kardos, a specialist who began to study the ideologies associated with the crown in the ig6os did not show much empathy towards the subject in his writing in I 967 : bourgeois ideologists used 'the szentkorona-eszme' to legitimize their nationalist policies — was the message he repeated ad nauseam. ${ }^{446}$ In the interwar years, the author went on, the holy crown idea had provided the theoretical basis for irredentism and 'concealed the class dictatorship. ${ }^{447}$ Two years later in a Századok article, he was nearly as hard on Eckhart as Sarlós had been. ${ }^{448}$ Yet the same author published in 1985 a narrow, Marxist, but competent, well written monograph on the history of the doctrine between I9I9 and 1944, showing empathy towards the subject, in which irredentism gets only one and half pages. ${ }^{449}$ By the time he published his second work in I992 (after the collapse of the Kádár régime) he had warmed to the subject to such an extent that this reader could not find a single reference to irredentism. The author now discovered the socially progressive elements of the 'crown idea' in Kossuth's writing, described Béla Szabó's work on the crown as 'the first significant formulation of polgári (bourgeois) political ideas' and was fulsome in his praise of Eckhart's scholarship (although

\footnotetext{
444 Parliament began the debate on the Amendments of the Constitution Bill on 5 June i990. The issue whether the so called 'Kossuth escutcheon' of the I 848 revolution or the escutcheon with the crown, used until i945, should replace the one used during the Kádár regime came up on i 8 June. After a tense and not particularly edifying debate the House decided that the issue would be dealt with in a separate bill which was passed by a large majority (for 258, against 28 abstained 35) on 3 July, i99o. Országgyûlési Értesitô, 2, pp. $865-68,873^{-74}$, I $006-$ I 3 , I 2 I $3-28$, г $266-70$.

445 See note 437 above.

446 'in general the main ambition of the advocates of nationalism has been and still is to create a "historical basis" for their views. The "historical arguments" are to secure a legitimacy of nationalist demands. The historical setting was not missing from the accessories of Hungarian nationalism either. The "idea" of the holy crown provided one of these settings: this train of thought contained constantly changing, mystical and diffuse ideas with the help of which bourgeois ideologists and politicians by reference to historical roots have justified and proved their current political aims and interests. They tried to secure the effectiveness and agitative force of this ideology chiefly by unrealistic exaggeration and actualization of the real and supposed role associated with the crown in the course of our history.' József Kardos, 'Sorsfordulók egy mitosz életében', Világosság, July/August i 967, pp. 444-49 (p. 444).

447 Ibid., pp. $447,448$.

448 Idem, 'Áz Eckhart-vita és a szentkorona-tan', Századok, I 03, i 969, pp. I I o4- I I 7.

449 Idem, A szentkorona története I9I9-1944, Budapest, I985, pp. 87-88.
} 
not quite understanding it). ${ }^{450}$ Following well established local tradition the author mentions nowhere his turn-about.

The revival of the cult of St Stephen and the tradition of the Holy Crown do not necessarily extend to the doctrine itself as valid constitutional law today. But even in that extreme form the doctrine has champions. István Kocsis makes clear in the preface of his book on the Holy Crown doctrine 'its past, present and future'451 that he does not regard the crown as a museum piece because:

The Holy Crown is still the subject of state power and the doctrine of the Holy Crown is not only a relic of a glorious Hungarian past but valid and enforceable public law [...] the doctrine of the Holy Crown has never been repudiated by the constitutionally formed Hungarian legislature [...] and we know that not even the lawfully elected Hungarian national assembly, the parliament, could put the Holy Crown doctrine out of force..$^{452}$

The author is a successful writer from Transylvania and his outlandish views on the constitution have not of course influenced the legal profession.

Yet the crown question was not settled by the inclusion of $\mathrm{St}$ Stephen's Crown in the national escutcheon in I 990. After I 994, when the Socialists and the Free Democrats were in office, politicians of the Right, particularly in the Smallholder party, demanded that the crown should be transferred from the National Museum to parliament and that the doctrine of the Holy Crown should be included in the revised Constitution. Their proposal in the House in i 996, however, did not get very far. The coincidence of two factors moved the cult of the crown further. One was the replacement of the Left-wing government by Viktor Orbán's right-of-centre government in I 998. The other factor was the celebration of the Millennium, which coincided with the coronation of St Stephen I in the year I ooo. The government appointed a kormánybiztos (commissar), István Nemeskürty, historian and ardent promoter of the Holy Crown tradition, to organize the events. St Stephen's Crown, as we may recall, was ceremonially transferred from the National Museum to parliament on I January 2000.453 The ministerial draft of the Millennium Bill had a long preamble which included the doctrine in a passage. This passage was eventually deleted because of strong opposition to it in parliament and by the Academy. ${ }^{454}$

${ }^{450}$ Idem, A szentkorona és a szentkorona-eszme története, Budapest, i 992, pp. 4I-46, 79-83. This work follows the revived usage 'Szent Korona' (capitalized) and was prefaced by Otto Habsburg.

451 The subtitle of Kocsis's Szent Korona.

${ }^{452}$ Ibid., pp. 5, I I and I 2. Kocsis's attitude to the doctrine's status today is comparable to Kmety's in I9 18-igi9, see note 350 above.

453 See p. 423 above.

454 See note 7 above. The final vote went for 226, against 65, abstained 6I: on 2 I December i 999, Az országgyûlés hiteles jegyzőkönyve, I I 2, pp. I6273-77. 
Thus the doctrine did not get into the Lawbook although it crept into the speech of the Republic's President on I January. ${ }^{455}$ The return of the Left to power in the Spring of 2002 has, for the time being, stopped any further innovations in the cult of the crown.

\section{Conclusions}

The central fact of the Hungarian crown tradition's history is the existence of St Stephen's Crown. The question which looks for some answer is why it came to be that the visible crown, an artefact, has played such a seminal role in Hungarian history. This role cannot be explained by foreign influences alone. While the crown tradition originated in European Christian religion, we cannot find strong analogies, at least in the history of European political culture, for the cult of an artefact that has practically run through the whole history of a country. A visitor would find in several European countries matchless collections of regalia that have played prominent roles in the past. Today they are, as treasured relics, mostly on display in museums. In contrast, the Hungarian crown, guarded in parliament to which it has been recently transferred, is still a living part of the political discourse. Can the endurance of this tradition be explained?

Perhaps the explanation is to be found in social structure: the permanent ascendancy of the large nobility over all the other social groups for much of the country's history. Italian humanists in King Matthias's court in the late fifteenth century (Enea Sílvio, Callimachus, Bonfini, Tubero, Ransano) viewed the nobility as rough uneducated soldiers proud of their Scythian background. ${ }^{456}$ The cult of a sacred object, we may surmise, served better this society in legitimizing authority than intellectually more demanding fictions like 'the king never dies'. But of course this explanation does not hold for modern times when the country has been led by a highly educated élite. Yet the invisible crown became an even more important part of political discourse than it had been before.

From I790 onwards the crown tradition has undergone major changes, whether invented or not, and it is these that should be explained. The tradition played a prominent role in I 790, in the I89os, in the interwar years and since i 990 . These have been periods of rapid social transformation. The nobility's movement in I 790 , in which the cult of the crown played such a prominent role, followed Joseph II's reckless attempt to drag Hungary out of its medieval conditions. In the late nineteenth and early twentieth centuries the political class, based on the gentry, was under increasing threat of losing its social position.

455 See p. 423 above and note I I .

456 Deér, Pogány m., pp. 238-55, a realistic description of the social-cultural conditions. 
And Hungarian society since the collapse of the Socialist system, which has coincided with the revival of the crown tradition, has been in turmoil. Yet mental constructs, even ones simpler than the crown tradition, cannot be satisfactorily explained by reference to social change. An explanation should be more specific.

If we are looking for specific political explanation, the long Habsburg connection provides the most obvious context. Historically, the relationship between Hungary and Austria grew out of the relationship between the crown and the ország. The distribution and balance of power between the alien dynasty and the large nobility depended on a few insecurely established institutions. The obligation of rex hereditarius to arrange his/her diaetalis coronation with an artefact which is in the secure possession of the other side, together with the Oath and the Diploma, provided the only institutional safeguard for the preservation of ország rights. This explanation obviously holds water for the period between Mohács and igi8, yet leaves unanswered the question regarding the medieval period, the interwar years and the recent revival of the tradition.

Perhaps the explanation lies in the mental sphere rather than in social structure or politics. Our view of the past is shaped by what we read into it from the present; on the other hand, we understand the present in terms of what we have constructed about the past. The use of words within a community is to an extent an autonomous development. Once the vocabulary of the Holy Crown is established the hypnotic power of words takes a permanent hold on minds. While this may be true as a part of an explanation it is (again) too abstract and not specific enough.

There is also a functional explanation which is currently advanced by many people. The Holy Crown tradition can be explained, so runs the argument, by the need that all communities have for symbols of identity. This observation is true but as an explanation it begs the question. Further, the Holy Crown tradition could be described as part of a 'cultural system' from which the new Hungarian 'imagined community' sprung in the early nineteenth century. ${ }^{457}$ As we have seen, the tradition played a central role in the 'origin and spread of nationalism'. Nationalism, however, still does not provide an answer to our question: why the crown? I should refrain from the customary evasion of historians in comparable situations by suggesting that the list of features together furnish the explanation. Instead of being overly preoccupied with establishing causes, the historian may not want to do more than place the subject in its social and cultural settings. At any

457 See Benedict Anderson, Imagined Communities: Reflections on the Origin and Spread of Nationalism, London, I99 I, esp. p. I 2. 
rate it is very likely to be a mistake to look for straightforward causes of highly complex historical phenomena that may belong even more to social anthropology than constitutional or intellectual history. What is undeniable is that a relic attributed to St Stephen, the visible crown, created a most effective metaphor for transmitting political messages for centuries.

Our survey of the political tradition associated with the invisible crown from the Middle Ages to the present suggests that there are no strong grounds suggesting that the tradition is based on a definable idea. Rather, the tradition consists of a compound, an unstable combination of several (partly contradictory) ideas. This itself is not at all surprising as the same can be said of other political terms and particularly of those that create traditions. Political ideas are seldom 'general'; they always express changing particular and moral perspectives. Those who do not recognize this fail to understand that the past is a different country.

What does lend coherence to the tradition of the Holy Crown is not some conceptual hard kernel but the permanence, for some eight hundred years, of the visible Crown of St Stephen. This jewel, which itself has had a remarkable narrative, ${ }^{458}$ has never been unambiguously separated from the invisible crown. Indeed, the ideas were always parasitical on the magic of St Stephen's Crown which has behaved like a magnet, attracting political rhetoric throughout Hungarian history. Hungarians rephrased their changing collective and frequently their sectional values, aspirations and programmes in reference to their visible crown.

The most radical transformation of the ideas associated with the crown occurred in the nineteenth century with the creation of the Holy Crown doctrine. As we have seen, Hungary for centuries represented an acute case of institutional and conceptual bipolarity between the royal power and the ország. It was a remarkable turn-about, with which Hungary's jurists should be credited, that corona Hungariae was moved over from the monarch's to the ország's side. The hereditary possession of the alien dynasty, the 'crown', was transformed to represent the sovereignty of the nation. Although the doctrine as a concept of legislative sovereignty was defective, ${ }^{459}$ nevertheless, the crown as the source of national sovereignty became a powerful icon in the political rhetoric of modern Hungarian nationalism.

458 See the apt title of the Hungarian edition of Benda-Fügedi Stephanskrone, note I above. Sándor Radnóti contrasts developments in Western Europe, where the invisible crown provided institutional continuity, with Eastern Europe, where the visible crown played a similar role, 'Üvegalmárium', p. 49. This idea is worth pursuing although it still does not explain the unparalleled duration of the Hungarian invisible crown's tradition.

459 See p. 482 above. 
The recent revival of the Holy Crown tradition largely fits in with the pattern established in the nineteenth century. Firstly, the doctrine today, as in the nineteenth century, is not a part of constitutional law but appears in political rhetoric and in textbooks on the history of constitutional law. ${ }^{460}$ Unlike the pre- 945 periods, however, the jurists keep themselves at a safe distance from the doctrine. As in the past, official attitudes to the crown tradition greatly depend on the political colour of the government that happens to be in office. 'Forty-Eighters' (Independentists) cherished the tradition much more than 'SixtySeveners' (Liberals) before igi8, just as Centre-Right governments support (restore) traditions rather than the Centre-Left governments today. Again, the champions of the tradition, and the doctrine in particular, insist today, as they used to in the nineteenth century and the interwar years, that the Holy Crown, as a fundamental source of national identity, was a serviceable idea. For Hungarian society was and is still not properly integrated. The Holy Crown tradition is conducive to social and national cohesion. It undoubtedly has been for many people; at the same time, however, it has been culturally divisive too. As we have seen, the doctrine creates social conflict as well as healing it.

Yet even the opponents of the Holy Crown tradition unwittingly testify to its strength. A distinguishing sign, if not the hallmark, of a successful mythos is its ability to neutralize critical analysis about itself. The Holy Crown tradition can easily pass this test. The tradition has been so powerful that it has successfully absorbed (indeed obliterated) the findings of Eckhart. For the opponents as much as the champions of tradition ignore what Eckhart clearly demonstrated over sixty years ago: that the crown as a corporate political concept, comprising the king and the nobility (or nation) evolved in the nineteenth century (rather than in the Tripartitum or even earlier); that the nobility shared power with the crown rather than in the crown; ${ }^{461}$ and that the doctrine itself was produced by jurists in the late nineteenth century. ${ }^{462}$

\footnotetext{
460 The various editions of Magyar alkotmánytörténet, ed. Barna Mezey, published in the I 990 , is a goulash of Marxist canon, Laband and the doctrine of the Holy Crown. 461 See page 446 and note I 34 above.

462 Iván Bertényi, a champion of the crown's political tradition and Sándor Radnóti, an opponent, equally hold Eckhart in high esteem. Radnóti would exhibit St Stephen's Crown in the National Museum, the right place for historical relics; yet he finds the mystical state theory of the Holy Crown doctrine in the Middle Ages: 'Üvegalmárium', p. 49. Bertényi invokes Eckhart's authority but argues that Werbőczy's idea of the Holy Crown was an appeal to 'noble democracy', an idea which leads to popular sovereignty: Bertényi, Szent Korona, p. I 50. Gyula Rugási, an opponent of the crown tradition, takes for granted that the 'doctrine of the Holy Crown' emerged sometime in the Middle Ages: 'Szellemképek', Holmi, I 2, 2000, pp. I33I-45 (p. I338). See also, Eckhart, Szentkorona, esp. pp. 204, 2 Io, and Szekfû's misinterpretations of Eckhart's views on p. 499 above.
} 
Finally, we ought to ask how far the jurists, who constructed the doctrine of the Holy Crown, were aware of what they were doing. After a lecture I gave in Holland over forty years ago on the making of the doctrine, the classical scholar, Károly Kerényi, advised me to make up my mind whether the Holy Crown tradition was a mythos or a pseudos. I am still unable to provide a satisfactory answer. It is, of course, quite clear that the cult surrounding St Stephen's Crown has generated a proper mythos. Scholars have not even been able to establish the provenance of the artefact, the tradition does not have an 'author', the crown's veneration has been a genuine 'uninvented', lasting tradition of a national community.

The ideas associated with the crown, until the late nineteenth century, appear in diverse uses in political discourse rather than in deliberately designed practices. Werbőczy did not 'invent' a theory; he used, on a single occasion, a convenient simile for a specific purpose. Nor is it plausible to suggest that Récsi, Csemegi or even Hajnik were engaged in inventing theories. Our survey showed that the ideas and attributions of the crown evolved very gradually even in the course of the nineteenth century until its last decade. They exhibited 'the strength and adaptability of genuine traditions' rather than 'invented ones'. ${ }^{463}$

The creation of the Holy Crown doctrine in the r8gos appears, however, to have some of the makings of a pseudos. The question is whether the jurists' doings fit what Eric Hobsbawm calls the invention of tradition: "where a "tradition" is deliberately invented and constructed by a single initiator'?464 Do we not have here the arch constructor, Győző Concha, whose retrospective invention of the doctrine read into the Middle Ages was then developed further by his colleagues at the Law Faculty in Budapest? Yet the case is not as straightforward as it looks. 'Pseudos' in the OED associates 'false', 'counterfeit', 'pretended', 'spurious' (in the sense of not genuine). False and spurious the doctrine certainly was in that it laid claims on a past that had never existed, but that itself may not be sufficient to qualify for being a pseudos. If veracity is the measure of a genuine tradition then (to give just one example) the cult of St Stephen's Crown would be disqualified by the belief in the Middle Ages that it was ab angelo privaretur.

We are left with the two other adjectives of the OED: 'counterfeit' and 'pretended'. Our problem here is that we can never be certain what goes on in other people's minds (sometimes not even in our own). We can only speculate about the extent to which the jurists themselves

463 On this, see Eric Hobsbawm and Terence Ranger (eds), The Invention of Tradition, Cambridge, I 984 , p. 8.

464 Ibid., p. 4 . 
were aware of being the doctrine's inventors. Yet it does appear that they honestly cherished their brainchild even to the point of absurdity. Concha and Timon were not forgers, they might have been fantasists but in their work they showed integrity: they followed their own light. Kmety, on the other hand, was an acute case. He adjusted his views to changing political circumstances and developed his constitutional position between two editions of his textbook. Similar doubts apply to historians today, who, without a flicker of the eye, shift their position in order to adjust to political changes.

It is easier to detect when rituals are deliberately invented than ideas. The taking of the visible crown to parliament (which was unprecedented) on 9 June i 896 for the millennial celebration of Hungary's conquest, the transference of St Stephen's Crown to a permanent site in parliament on I January $2000,{ }^{465}$ and the crown's travel by boat to Esztergom on i6 August 200 I as a part of the celebration of St Stephen's Day have been telling examples. It may be argued that Hungary has merely followed other European countries where the heyday of invented public traditions were the decades before the First World War ${ }^{466}$ - except that, as in some other respects, Hungary is lagging behind by several decades. It may be argued that as the importance of public rituals has declined in Western Europe since the Second World War, we should expect the same to happen in Hungary. It is, however, too much to assume that a cult that has mysteriously surrounded an inanimate artefact through almost the entire history of Hungary should in a few decades fade away.

465 In today's Hungary the chief inventor of tradition has been the commissar appointed by the Orbán government to organize the millennial celebrations (see page 504 above). The left wing press in Budapest had a field day when it turned out that on I January 2000 St Stephen's Crown was ceremoniously (but out of ignorance) taken up to parliament farral elöre (backside first) - a rather typical mishap when traditions are created.

466 On the invented traditions of the British monarchy in the late nineteenth century see David Cannadine, Ornamentalism: How the British Saw Their Empire, London, 200 i, ch. 8, esp. p. I 06 . 